Prepared in cooperation with Frederick County, Maryland

\title{
Sources of Fine-Grained Sediment in the Linganore Creek Watershed, Frederick and Carroll Counties, Maryland, 2008-10
}
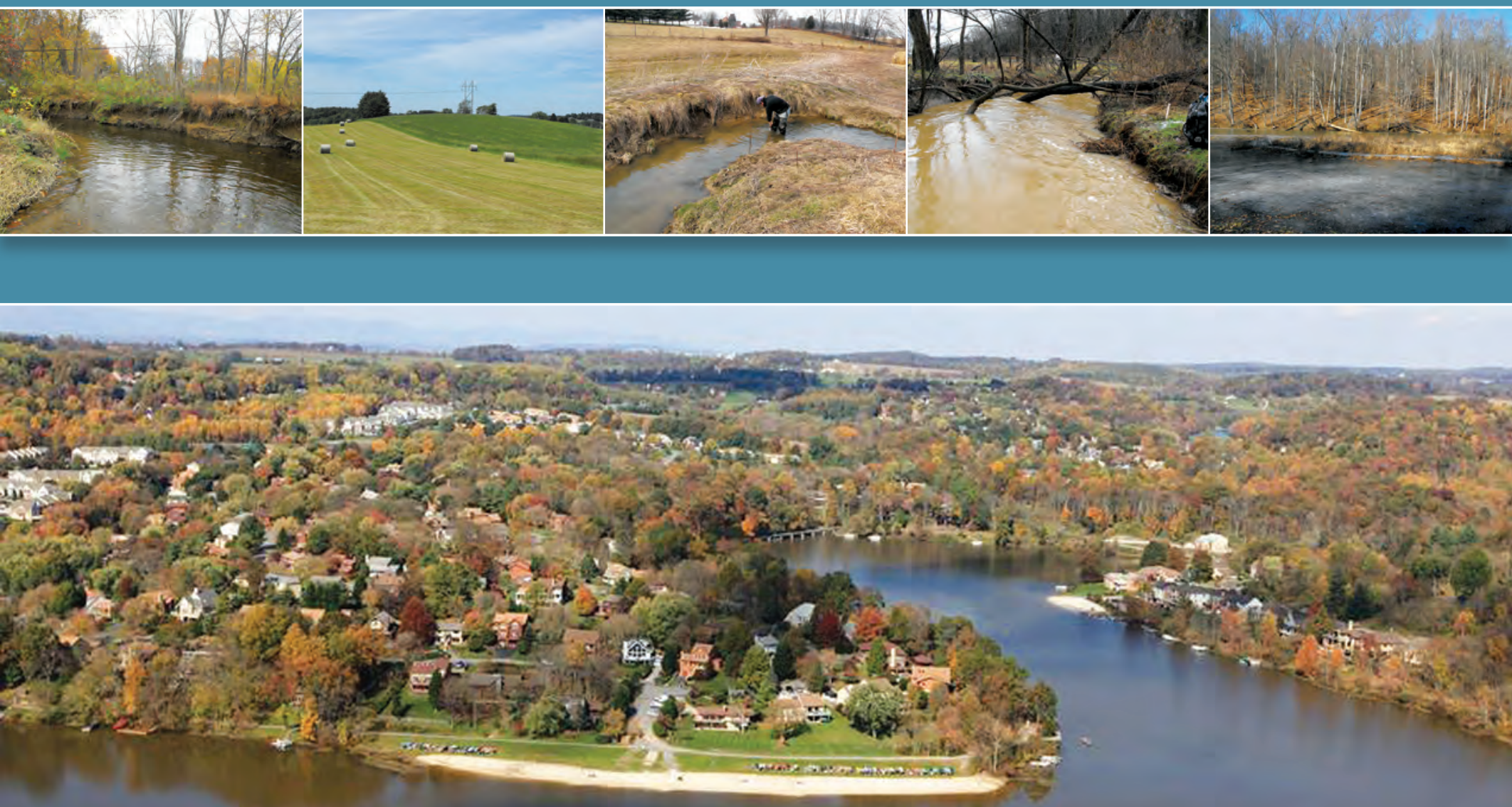

Scientific Investigations Report 2014-5147

U.S. Department of the Interior

U.S. Geological Survey 
Cover. (Top photographs) Sediment source area types sampled in the Linganore Creek watershed. Photographs by Allen Gellis, U.S. Geological Survey.

(Bottom photograph) Aerial view of the Lake Linganore community at Eaglehead and Coldstream Beach approximately 5 kilometers (3.1 miles) downstream from U.S. Geological Survey streamflow-gaging station 01642438 and the Linganore Creek watershed study area. Photograph by Rex Reed of Amberlea Photography \& Design, LLC for Data Base Marketing (DBM), Inc. 


\section{Sources of Fine-Grained Sediment in the Linganore Creek Watershed, Frederick and Carroll Counties, Maryland, 2008-10}

By Allen C. Gellis, Gregory B. Noe, John W. Clune, Michael K. Myers,

Cliff R. Hupp, Edward R. Schenk, and Gregory E. Schwarz

Prepared in cooperation with

Frederick County, Maryland

Scientific Investigations Report 2014-5147 


\title{
U.S. Department of the Interior SALLY JEWELL, Secretary
}

\section{U.S. Geological Survey Suzette M. Kimball, Acting Director}

\author{
U.S. Geological Survey, Reston, Virginia: 2015
}

For more information on the USGS - the Federal source for science about the Earth, its natural and living resources, natural hazards, and the environment, visit http://www.usgs.gov or call 1-888-ASK-USGS

For an overview of USGS information products, including maps, imagery, and publications, visit http://www.usgs.gov/pubprod

To order this and other USGS information products, visit http://store.usgs.gov

Any use of trade, product, or firm names is for descriptive purposes only and does not imply endorsement by the U.S. Government.

Although this report is in the public domain, permission must be secured from the individual copyright owners to reproduce any copyrighted materials contained within this report.

Suggested citation:

Gellis, A.C., Noe, G.B., Clune, J.W., Myers, M.K., Hupp, C.R., Schenk, E.R., and Schwarz, G.E., 2015, Sources of finegrained sediment in the Linganore Creek watershed, Frederick and Carroll Counties, Maryland, 2008-10:

U.S. Geological Survey Scientific Investigations Report 2014-5147, 56 p., http://dx.doi.org/10.3133/sir20145147.

ISSN 2328-0328 (online) 


\section{Contents}

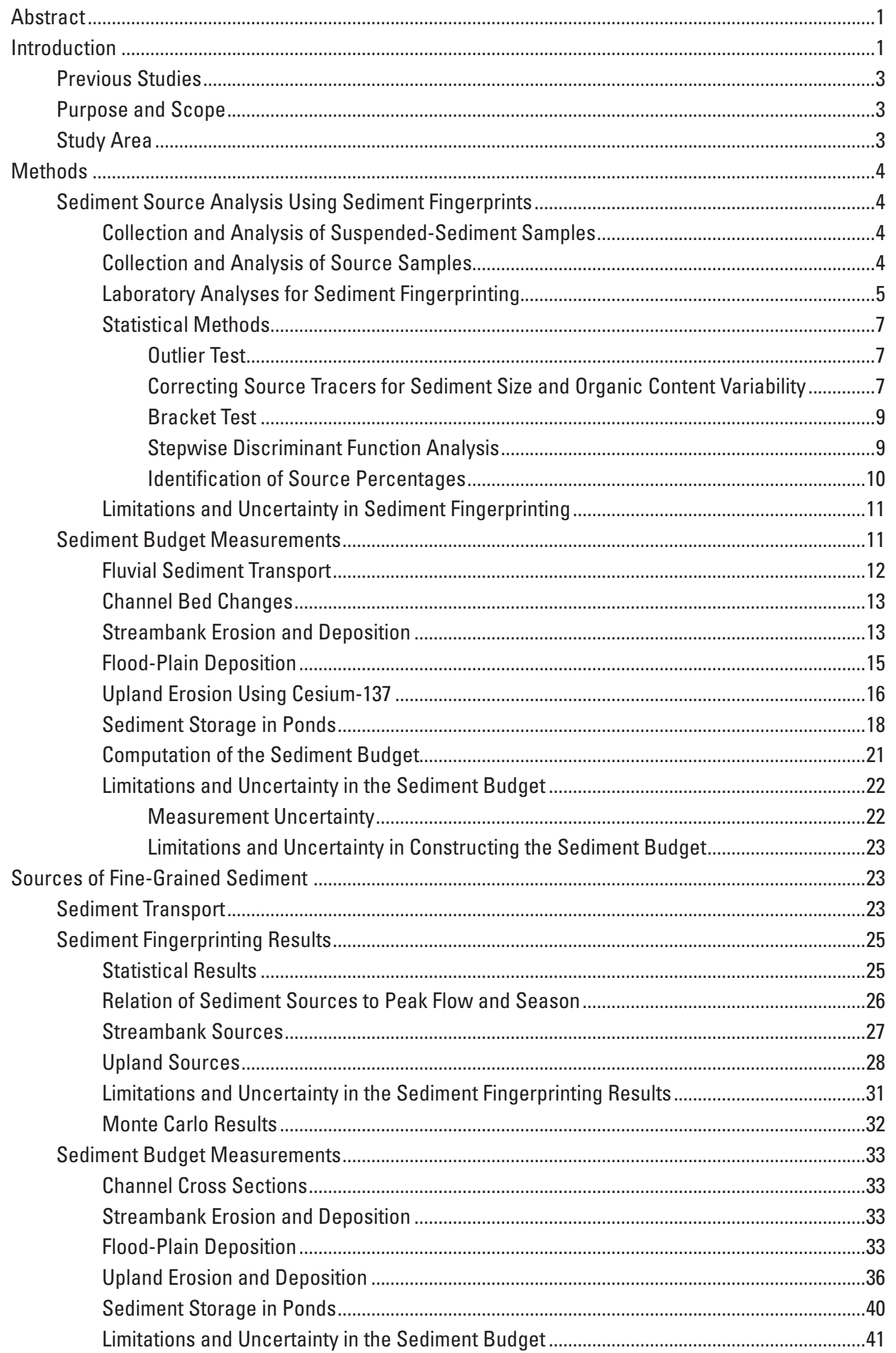




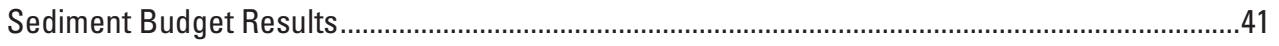

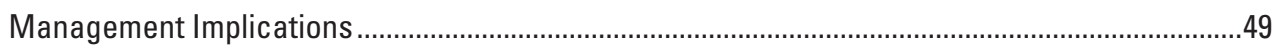

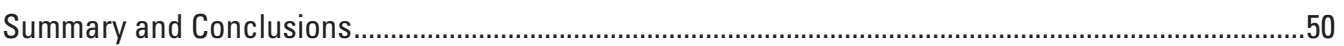

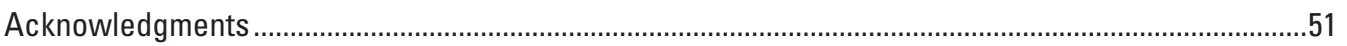

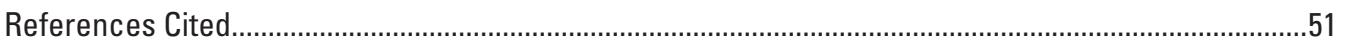

Appendixes 1-13 are available online as Excel files at http://pubs.usgs.gov/sir/2014/5147/appendix/.

Appendix 1. Percentage of silt and clay in suspended-sediment samples collected at Linganore Creek, Md. between July 18, 2008 and August 28, 2009.

Appendix 2. Summary of tracers analyzed from fluvial samples collected in Linganore Creek, August 1, 2008 through October 1, 2010.

Appendix 3. Summary of tracer results for streambank source samples.

Appendix 4. Samples taken for sediment-source analysis in agricultural (cropland and pasture) areas.

Appendix 5. Summary of tracer results for forest source samples.

Appendix 6a. Summary of sediment-source results for the 36 sampled events.

Appendix 6b. Minimum and maximum temperatures recorded at the Frederick Airport, Md. for sampled storms that occur in late fall to early spring.

Appendix 7a. Summary of sites where pins were installed to measure streambank changes.

Appendix 7b. Summary of flood-plain measurements made at Linganore Creek, Md., August 1, 2008 through December 31, 2010.

Appendix 8. Proportion II model results on ${ }^{137} \mathrm{Cs}$ measurements made on agricultural sites, Linganore Creek, Md.

Appendix 9. Diffusion and migration model results on ${ }^{137} \mathrm{Cs}$ measurements made on forested sites, Linganore Creek, Md.

Appendix 10. Summary of ${ }^{137} \mathrm{C}$ s at reference sites in Linganore Creek, Md.

Appendix 11. Characteristics of ponds in the Linganore Creek watershed.

Appendix 12. Measurement uncertainty in bank pin measurements, Difficult Run, Va., July 8, 2011.

Appendix 13. Measurement uncertainty in flood-plain pad measurements, Difficult Run, Va., July 15, 2011.

\section{Figures}

1. Map showing location of study area, Linganore Creek watershed, Frederick and Carroll Counties, Maryland.

2. Map showing location of sampling sites for sediment fingerprinting analysis, Linganore Creek watershed study area, Frederick and Carroll Counties, Maryland

3. Diagram showing outline of statistical operations used in determining sediment sources using the sediment fingerprinting approach.....

4. Graph showing example of how the size-correction factor is applied to a source group.

5. Schematic diagram showing the geomorphic elements where erosion and deposition were measured or estimated in Linganore Creek, Maryland 
6. Map showing location of channel measurements for cross sections, flood-plain deposition, and bank erosion in the Linganore Creek watershed study area, Frederick and Carroll Counties, Maryland

7. Map showing location of sampling sites for Cesium-137 in the Linganore Creek watershed study area, Frederick and Carroll Counties, Maryland...

8. Photograph showing illustration of the Cesium-137 sampling technique used in agricultural and forested areas in the Linganore Creek watershed

9. Map showing location of ponds used in the sediment budget, Linganore Creek watershed study area, Frederick and Carroll Counties, Maryland

10. Graph showing regression analysis of drainage area and sediment trap efficiency used to estimate trap efficiency for ponds in the Linganore Creek watershed, Maryland

11. Graph showing average monthly rainfall for the study period (July 2008December 2010) and period of record (January 1950-May 1990; April 2004-June 2008) for Frederick, Maryland

12. Graphs showing results of sediment fingerprinting analysis for 36 storm events in Linganore Creek, September 6, 2008 through September 30, 2010, showing sediment sources as $(A)$ source results averaged for all samples collected during the event, and $(B)$ source results weighted by the sediment load of that sample divided by the total sediment load for that event.

13. Graphs showing $(A)$ relation of peak flow to suspended-sediment load for sampled events. Relation of peak flow to storm-weighted source percentages for $(B)$ streambanks, $(C)$ agriculture, and $(D)$ forest..

14. Graphs showing relation of suspended-sediment load to storm-weighted source percentages in $(A)$ streambanks, $(B)$ agriculture, and $(C)$ forest

15. Graphs showing storm-weighted source percentages shown by months and season for: $(A)$ streambanks, a T-test $(p=0.023$; data normally distributed) run on the data indicated a statistical difference between winter and non-winter months; $(B)$ agriculture, a T-test $(p=0.009$; data normally distributed) run on the data indicated a statistical difference between winter and non-winter months; and (C) forest, a Mann-Whitney Rank Sum test ( $p=0.031$; data non-normally distributed) run on the data indicated a statistical difference between spring-summer and fall-winter months. (D) peak flow by month and season; a Mann-Whitney Rank Sum test $(p=0.046$; data non-normally distributed) run on the data indicated a statistical difference between winter and non-winter months

16. Graphs showing bed changes in Linganore Creek determined through cross-section resurveys, August 1, 2008-December 24, 2010.

17. Graph and maps showing $(A)$ streambank changes determined through bank pin measurements, and reach-averaged streambank changes,

$(B)$ centimeters per year, and $(C)$ square centimeters per year in Linganore

Creek watershed study area, Frederick County, Maryland, August 11, 2008

through December 24, 2010..

18. Graph showing deposition measured on individual flood-plain pads

$(n=79)$ for Linganore Creek, August 1, 2008-December 31, 2010, displayed by stream order.

19. Graph showing relation of reach-averaged flood-plain deposition compared to contributing area, Linganore Creek, Maryland.

20. Graph showing summary of erosion on agricultural and forested areas using the Cesium-137 method, Lake Linganore, Maryland

21. Graph showing distribution of ponds by area draining to ponds, Linganore

Creek, Maryland. 


\section{Tables}

1. List of elements used as tracers to identify the sources of fine-grained sediment.

2. Equations used to correct for bias in untransforming the tracers

3. Summary of monthly and annual suspended-sediment loads for Linganore Creek near Libertytown, Maryland, August 2008 through December 2011

4. Results of test to determine if regression of the median grain size of material less than 63 microns $\left(D_{50}\right)$ compared to tracer activity in source samples is significant

5. Results of test to determine if regression of total organic carbon compared to tracer activity in source samples is significant.

6. Statistical tests (bracket test, normality tests, and Stepwise Discriminant Function Analysis [DFA]) performed on tracers for all source types after a size and organic correction were applied

7. Unmixing model results for 36 storm events in Linganore Creek.

8. Summary of measurements used to determine channel bed changes, Linganore Creek, Maryland.

9. Summary of measurements used in the calculation of streambank erosion

10. Results of forward stepwise regression on explanatory variables used to describe response variable of flood-plain deposition .

11. Summary of modeled flood-plain deposition at surveyed cross sections

12. Agricultural and forest rates of erosion using the Cesium-137 method

13. Summary of erosion and deposition in contributing areas to ponds from the channel bed, channel banks, flood plains, and upland areas (agriculture and forest)

14. Limitation and uncertainty in laboratory analysis and field measurements used in the sediment budget and sediment fingerprinting analysis

15. Final construction sediment budget based on field measurements of channel banks, channel beds, and flood plains, Cesium-137 inventories on agriculture and forested areas, storage of sediment estimated in ponds, and net sediment budget.

16. Summary of sediment budget in terms of erosion (input), storage, and delivery (equation 8)

17. Accounting of sediment storage by combining the sediment fingerprinting results with the sediment budget results. 


\section{Conversion Factors}

\begin{tabular}{|c|c|c|}
\hline Multiply & By & To obtain \\
\hline \multicolumn{3}{|c|}{ Length } \\
\hline micron $(\mu \mathrm{m})$ & $3.9370 \times 10^{-5}$ & inch (in.) \\
\hline centimeter $(\mathrm{cm})$ & 0.3937 & inch (in.) \\
\hline millimeter (mm) & 0.03937 & inch (in.) \\
\hline meter $(\mathrm{m})$ & 3.281 & foot $(\mathrm{ft})$ \\
\hline kilometer (km) & 0.6214 & mile (mi) \\
\hline kilometer (km) & 0.5400 & mile, nautical (nmi) \\
\hline meter $(\mathrm{m})$ & 1.094 & yard $(y d)$ \\
\hline \multicolumn{3}{|c|}{ Area } \\
\hline square meter $\left(\mathrm{m}^{2}\right)$ & 0.0002471 & acre \\
\hline hectare (ha) & 2.471 & acre \\
\hline square kilometer $\left(\mathrm{km}^{2}\right)$ & 247.1 & acre \\
\hline square centimeter $\left(\mathrm{cm}^{2}\right)$ & 0.001076 & square foot $\left(\mathrm{ft}^{2}\right)$ \\
\hline square meter $\left(\mathrm{m}^{2}\right)$ & 10.76 & square foot $\left(\mathrm{ft}^{2}\right)$ \\
\hline square centimeter $\left(\mathrm{cm}^{2}\right)$ & 0.1550 & square inch $\left(\mathrm{ft}^{2}\right)$ \\
\hline hectare (ha) & 0.003861 & square mile $\left(\mathrm{mi}^{2}\right)$ \\
\hline square kilometer $\left(\mathrm{km}^{2}\right)$ & 0.3861 & square mile $\left(\mathrm{mi}^{2}\right)$ \\
\hline \multicolumn{3}{|c|}{ Volume } \\
\hline cubic meter $\left(\mathrm{m}^{3}\right)$ & 6.290 & $\begin{array}{l}\text { barrel (petroleum, } 1 \text { barrel }=42 \\
\text { gal) }\end{array}$ \\
\hline liter $(\mathrm{L})$ & 33.82 & ounce, fluid (fl. oz) \\
\hline cubic meter $\left(\mathrm{m}^{3}\right)$ & 35.31 & cubic foot $\left(\mathrm{ft}^{3}\right)$ \\
\hline cubic meter $\left(\mathrm{m}^{3}\right)$ & 1.308 & cubic yard $\left(\mathrm{yd}^{3}\right)$ \\
\hline cubic kilometer $\left(\mathrm{km}^{3}\right)$ & 0.2399 & cubic mile $\left(\mathrm{mi}^{3}\right)$ \\
\hline \multicolumn{3}{|c|}{ Flow rate } \\
\hline cubic meter per second $\left(\mathrm{m}^{3} / \mathrm{s}\right)$ & 35.31 & cubic foot per second $\left(\mathrm{ft}^{3} / \mathrm{s}\right)$ \\
\hline \multicolumn{3}{|c|}{ Mass } \\
\hline gram $(\mathrm{g})$ & 0.03527 & ounce, avoirdupois (oz) \\
\hline kilogram $(\mathrm{kg})$ & 2.205 & pound avoirdupois (lb) \\
\hline megagram $(\mathrm{Mg})$ & 1.102 & ton, short $(2,000 \mathrm{lb})$ \\
\hline megagram $(\mathrm{Mg})$ & 0.9842 & ton, long $(2,240 \mathrm{lb})$ \\
\hline \multicolumn{3}{|c|}{ Density } \\
\hline kilogram per cubic meter $\left(\mathrm{kg} / \mathrm{m}^{3}\right)$ & 0.06242 & pound per cubic foot $\left(\mathrm{lb} / \mathrm{ft}^{3}\right)$ \\
\hline \multicolumn{3}{|c|}{ Radioactivity } \\
\hline becquerel per liter $(\mathrm{Bq} / \mathrm{L})$ & 7.027 & picocurie per liter $(\mathrm{pCi} / \mathrm{L})$ \\
\hline \multicolumn{3}{|c|}{ Yield } \\
\hline $\begin{array}{l}\text { megagram per square kilometer } \\
\left(\mathrm{Mg} / \mathrm{km}^{2}\right)\end{array}$ & 2.855 & ton per square mile (ton $\left./ \mathrm{mi}^{2}\right)$ \\
\hline kilogram per square meter $\left(\mathrm{kg} / \mathrm{m}^{2}\right)$ & 0.2048 & pound per square foot $\left(\mathrm{lb} / \mathrm{ft}^{2}\right)$ \\
\hline megagram per hectare $(\mathrm{Mg} / \mathrm{ha})$ & 0.446 & tons per acre (ton/acre) \\
\hline
\end{tabular}

Water year is defined from 0 ctober 1 of the previous year to September 30 of the current year. 



\title{
Sources of Fine-Grained Sediment in the Linganore Creek Watershed, Frederick and Carroll Counties, Maryland, 2008-10
}

\author{
By Allen C. Gellis, Gregory B. Noe, John W. Clune, Michael K. Myers, Cliff R. Hupp, \\ Edward R. Schenk, and Gregory E. Schwarz
}

\section{Abstract}

Sediment fingerprinting quantifies the delivery of finegrained sediment from a watershed and sediment-budget measurements quantify the erosion and deposition of fine-grained sediment. Both approaches were used in the agricultural and forested 147-square-kilometer $\left(\mathrm{km}^{2}\right)$ Linganore Creek watershed in Maryland from August 1, 2008 through December 31, 2010, to determine the sources of fine-grained (less than 63 microns) sediment, and the amount of fine-grained sediment eroded from and deposited on streambanks, flood plains, channel beds, and agricultural and forested uplands. Sedimentweighted results of sediment fingerprinting for 194 suspendedsediment samples collected during 36 storms indicate that streambanks contributed 52 percent of the annual fine-grained suspended-sediment load, agriculture (cropland and pasture) contributed 45 percent, and forests contributed 3 percent. Fifty-four percent of the Linganore Creek watershed is agriculture and 27 percent is forest.

Sediment-budget calculations were based on field measurements and photogrammetric analyses and indicated that the highest percentage of fine-grained sediment was eroded from agriculture ( 86 percent), followed by streambanks (10 percent), forests ( 3 percent), and the channel bed (less than 1 percent). Results of the sediment budget indicated that the highest percentage of fine-grained sediment was stored in ponds (57 percent), followed by flood plains ( 32 percent), streambanks ( 6 percent), and the channel bed ( 5 percent). Typical of most sediment budgets, the final sediment budget indicated erosion of $4.70 \times 10^{7}$ kilograms per year $(\mathrm{kg} / \mathrm{yr})$, which is higher than the fine-grained suspended-sediment load leaving the watershed $\left(5.45 \times 10^{6} \mathrm{~kg} / \mathrm{yr}\right)$. The differences in the sediment budget and the measured mass leaving the watershed could be due to an overestimation of erosion using the Cesium-137 method and (or) not adequately defining and measuring storage areas.
Management implications of this study indicate that both agriculture and streambanks are important sources of sediment in Linganore Creek where the delivery of agriculture sediment was 4 percent and the delivery of streambank sediment was 44 percent. Fourth order streambanks, on average, had the highest rates of bank erosion. Combining the sediment fingerprinting and sediment budget results indicates that 96 percent of the eroded fine-grained sediment from agriculture went into storage. Flood plains and ponds are effective storage sites of sediment in the Linganore Creek watershed. Flood plains stored 8 percent of all eroded sediment with 4th and 5th order flood plains, on average, storing the most sediment. Small ponds in the Linganore Creek watershed, which drained 16 percent of the total watershed area, stored 15 percent of all eroded sediment. Channel beds were relatively stable with the greatest erosion generally occurring in 4th and 5th order streams.

\section{Introduction}

In the Chesapeake Bay and its tributaries, fine-grained sediment is a major cause of ecological degradation (Brakebill and others, 2010; Langland and others, 2012). Sediment has an adverse effect on the health of streams in the bay watershed, and on submerged aquatic vegetation and living resources in the estuary; it results in degraded water quality, loss of habitat, and population declines in biological communities. Sediment also is associated with and transports other contaminants, such as phosphorous.

Linganore Creek (fig. 1) is included on Maryland's list of streams for sediment impairment (Maryland Department of the Environment, 2008). The study area is upstream of Lake Linganore, a reservoir that is used for water supply and recreation in Frederick County. Lake Linganore is also experiencing a sedimentation problem (Sekellick and Banks, 2010). There has been a Total Maximum Daily Load (TMDL) issued 


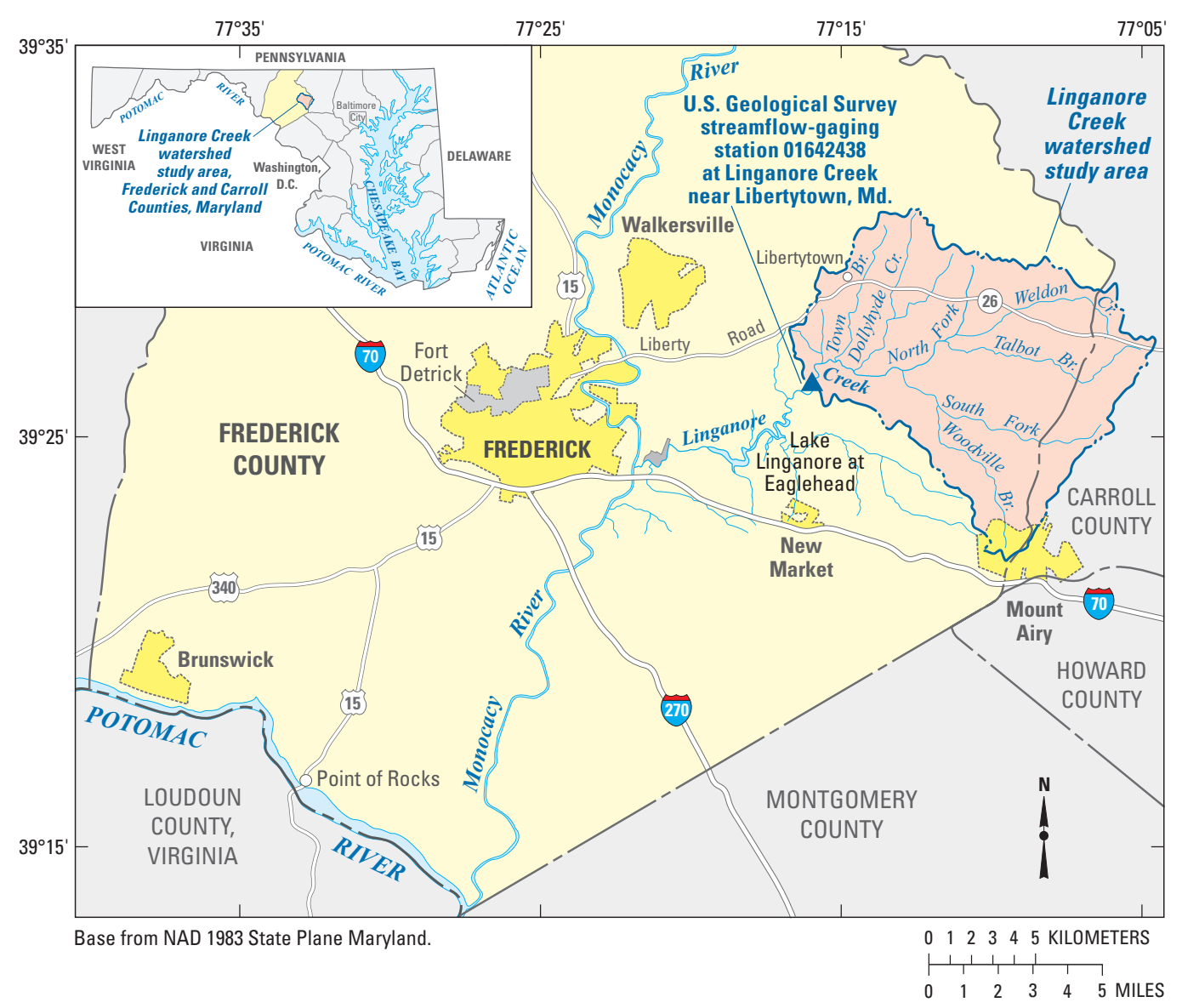

Figure 1. Location of study area, Linganore Creek watershed, Frederick and Carroll Counties, Maryland.

for Lake Linganore for both phosphorous and sediment. A TMDL is the amount of pollutant that a waterbody can assimilate and still meet its designated use (Maryland Department of Natural Resources, 2004). Therefore, identifying the significant sources of fine-grained sediment in the upper parts of Linganore Creek can assist in developing strategies to reduce sediment transported to Lake Linganore and improve aquatic conditions, reservoir storage capacity, and reduce treatment costs.

In characterizing sediment sources, an important first step is proportioning the sediment that is derived from uplands (such as agriculture) compared to channel (such as streambanks) sources. This first step is important because management strategies designed to reduce sediment from these sources would have very different approachesreducing agricultural sources would involve soil conservation and tilling practices whereas addressing channel sources of sediment may involve stream restoration. The sediment fingerprinting approach quantifies the relative importance of the potential sediment sources in a watershed. The sediment budget approach provides information on the magnitude of the sediment fluxes and the links between sources, sinks, and sediment output. Combining the two approaches can provide resource managers with information on where to target measures to reduce erosion, sediment delivery, and the net transport of sediment (Gellis and Walling, 2011). Areas where sediment is stored can also be determined by combining the sediment fingerprinting and sediment budget approaches.

In Linganore Creek, upland sources of sediment are related to land cover and land-use practices, which include agriculture (cropland and pasture) and forests. Erosion on upland surfaces can occur through sheetwash, rilling, gullying, and mass movements. Periods of heavy rain that lead to saturated excess overland flow or infiltration excess overland flow can erode and mobilize upland sediment. Gellis and others (2009) showed that during two of four sampled events in the Pocomoke River, a tributary of the Chesapeake Bay in Delaware and Maryland, upland sediment (agriculture and forest) was an important source when the sampled storms were likely to have produced overland flow, which is necessary to erode surface sediment. 
Channel sources are typically the channel bed and streambanks. The channel bed can be a source of sediment in incising channels. However, the beds of the main stem and tributaries in many watersheds are not considered as sediment sources, since in the absence of significant channel incision, sediment mobilized from the channel bed is likely to reflect temporary storage of sediment originating from upstream sources, and is therefore not treated as a separate source (Gellis and others, 2009).

Although upland sediment sources in urban areas may include open space (lawns and parks), construction sites, and street residue, the majority of sediment in urban areas is from streambank erosion (Devereux and others, 2010). Because of the small developed or urban area in the Linganore Creek watershed (8 percent), only changes in streambanks and streambeds, and flood-plain deposition were measured in urban areas.

Streambanks can be an important sediment source and erode by three mechanisms: (1) freeze-thaw processes (Wolman, 1959; Wynn, 2006), (2) fluvial erosion (Julian and Torres, 2006; Wynn, 2006), and (3) mass wasting (Wynn, 2006; Darby and others, 2007). Freeze-thaw action of the bank surfaces causes the soil to expand and loosen. The material that is loosened is readily available for transport by a range of flows that inundate the bank surface (Wolman, 1959; Lawler, 1986). Fluvial erosion is the detachment, entrainment, and removal of particles or aggregates from the streambank by the hydraulic forces of water. Hydraulic forces are related to the shear stress that the flow exerts on the bank. Sediment grain size, the cohesiveness of grains, and vegetation are also important in whether streambanks are erodible (Wynn, 2006). Hooke (1979) and Julian and Torres (2006) performed statistical analysis on the factors controlling bank erosion and determined that peak flow best predicts bank erosion. Mass wasting is the failure of all or part of the streambanks as a result of slope instabilities. Mass failures can occur from fluvial erosion undercutting the toe of the streambanks and creating unstable conditions leading to bank failure (Simon and others, 2000). Bank failures and mass wasting are common during the recessional period of stormflow, when seepage forces overcome the resistance of the grain's cohesion and the banks may fail (Simon and others, 2000; Fox and others, 2007).

Linganore Creek also is part of a network of small watersheds in the Chesapeake Bay watershed where the U.S. Geological Survey (USGS) and its partners are studying the erosion, transport, storage, and delivery of fine-grained sediment (Gellis and Brakebill, 2013). The USGS partnered with Frederick County, Maryland on a study to determine the sources of fine-grained sediment using the sediment fingerprinting and sediment budget approaches in the Linganore Creek watershed. This report presents the results of a study in the upper parts of the Linganore Creek watershed, Maryland to identify the important sources of fine-grained sediment using the sediment fingerprinting and sediment budget approaches.

\section{Previous Studies}

In the Chesapeake Bay watershed, both upland and channel sources have previously been identified by using the sediment fingerprinting approach in several small watersheds. In the agricultural watersheds (Little Conestoga Creek, and the Pocomoke River), the primary sediment sources that were identified were streambanks, and croplands (Gellis and others, 2009). In the agricultural Mill Stream Branch watershed, streambanks were 100 percent of the sediment sources for five suspended-sediment samples (Banks and others, 2010; Massoudieh and others, 2012). In the mixed land-use (urban, agriculture, and forest) Mattawoman Creek watershed, significant sources of sediment included cropland, construction sites, and forests (Gellis and others, 2009). Streambanks, street residue, and upland areas were the primary sources in the urban Anacostia River watershed (Devereux and others, 2010). Results of sediment fingerprinting for watersheds in the Chesapeake Bay watershed indicate that sediment sources vary among the watersheds, partly as a result of differences in past and present land use and geology.

\section{Purpose and Scope}

This report describes a sediment-source study conducted in the upper parts of the Linganore Creek watershed in Maryland from August 1, 2008 to December 31, 2010. This report also describes field and statistical methods used to determine the source(s) of fine-grained sediment using the sediment fingerprinting and sediment budget approaches. The report is also intended to provide information that will help land managers and water-resource managers make more informed decisions about sediment TMDLs and sedimentation of Lake Linganore.

\section{Study Area}

The study was conducted in the upper parts of Linganore Creek, a tributary to the Monocacy River that drains parts of Frederick and Carroll Counties, Maryland (fig. 1). Located in the Piedmont Physiographic Province, the area is characterized by rolling hills and moderately to deeply incised, well-drained valleys with altitudes ranging from near sea level to more than 275 meters (m) above sea level (DiLisio, 1983). The Piedmont Physiographic Province also has the highest sediment yields of any physiographic province in the Chesapeake Bay watershed (Gellis and others, 2009). Soils in the Linganore Creek watershed are primarily loams, silt loams, and gravelly loams of the Mt. Airy, Glenelg, and Blocktown Series developed on weathered phyllite and schist (Kraft, 2002). Slope percentages for the Linganore Creek watershed derived from $30-\mathrm{m}$ cells $(\mathrm{n}=163,022)$ created from the 2004 National Elevation Dataset (NED) indicate that the 25th, 50th, and 75th percentiles of slopes are 4.9 percent, 7.6 percent, and 10.7 percent, respectively. 
Precipitation in the basin averaged 1,047 millimeters per year (mm/yr) (U.S. Department of Commerce, 2011). Temperatures range from a July mean of 26 degrees Celsius to a December mean of 0.7 degrees Celsius (U.S. Department of Commerce, 2011; Sekellick and Banks, 2010). Land use in 2006 in the 147-square-kilometer $\left(\mathrm{km}^{2}\right)$ watershed above Lake Linganore was 27 percent forest, 26 percent hay and pasture (herein referred to as pasture), 36 percent cropland, 8 percent developed, and 3 percent other (Fry and others, 2011). The agriculture acreage is made up primarily of corn, wheat, barley, soybean, and pasture/hay (U.S. Department of Agriculture, 2009). Cultivated crops are planted from April to May and harvested during August and September. Both till and no-till operations are used. Pasture land is used for livestock grazing and dairy. Forests are primarily secondary growth forests, which developed after land clearing in the late 18th and early 19th centuries for agriculture (Sprague and others, 2006). During the study period, forests were not managed for commercial uses.

\section{Methods}

Source analysis of fine-grained sediment in Linganore Creek was accomplished by using the sediment fingerprinting and sediment budget approaches. These approaches incorporated both field and laboratory procedures.

\section{Sediment Source Analysis Using Sediment Fingerprints}

Source analysis of fine-grained sediment (silts and clays) using the sediment fingerprinting approach was conducted in the watershed draining to USGS streamflow-gaging station 01642438 (Linganore Creek near Libertytown, Md., drainage area $147 \mathrm{~km}^{2}$ ). The sediment fingerprinting approach provides a direct method for quantifying watershed sources of finegrained suspended sediment (Collins and others, 1997; Motha and others, 2003; Gellis and others, 2009). This approach entails the identification of specific sources through the establishment of a minimal set of physical and (or) chemical properties, such as tracers that uniquely identify each source in the watershed. Suspended sediment collected under different flow conditions exhibits a composite, or fingerprint, of these properties that allows them to be traced back to their respective sources. Tracers that have successfully been used as fingerprints include mineralogy (Motha and others, 2003), radionuclides (Walling and Woodward 1992; Collins and others, 1997; Nagle and others, 2007), trace elements (Devereux and others, 2010), magnetic properties (Slattery and others, 2000), and stable isotope ratios $\left({ }^{13} \mathrm{C} /{ }^{12} \mathrm{C}\right.$ and ${ }^{15} \mathrm{~N} /{ }^{14} \mathrm{~N}$ ) (Papanicolaou and others, 2003). Sources of sediment include, but are not limited to, upland land use and land cover (such as agriculture and forest), and the channel corridor (streambanks). By comparing the fingerprints of the suspended-sediment samples to the fingerprints of the source samples, and using a statistical "unmixing" model, the sources of the suspended sediment can be apportioned.

\section{Collection and Analysis of Suspended-Sediment Samples}

Fine-grained suspended-sediment samples were collected at the USGS streamflow-gaging station during storm events in Linganore Creek watershed from August 1, 2008 through December 31, 2010 by an automatic sampler that was programmed to activate when water levels in the stream exceeded a set gage height. Water was pumped sequentially over the storm hydrograph into 1-liter (L) plastic bottles. When possible, suspended sediment also was collected during storm events using conventional U.S. Series depth-integrating manual isokinetic samplers (a DH-81 and a US D-74). Suspended-sediment samples were centrifuged (1 to $4 \mathrm{~L}$ ) at the USGS Atlanta Sediment Lab facility. Because the goal was to determine the sources of fine-grained sediment, and most of the tracer's activity is found on the fine material, sand was removed from the samples by wet sieving the samples through a 63-micron $(\mu \mathrm{m})$ polyester sieve. Due to mass constraints in the lab analysis of sediment, individual storm samples could not be analyzed and storm samples taken across the hydrograph were combined into one or several samples.

\section{Collection and Analysis of Source Samples}

Sediment-source samples were collected from upland source areas and streambanks (fig. 2). After discussions with local landowners, it was determined that cropland and pasture fields transition over time, and sites that are now in permanent pasture were cropland within the last two decades; therefore, cropland and pasture were combined into one sediment source category-agriculture.

Site selection for forest and agricultural upland samples was based on obtaining a spatially representative dataset and landowner permission. Streambank site selection was based on a randomized design using a geographic information system (GIS). A GIS coverage of streams was created for the Linganore Creek watershed. The streams were classified by Strahler order (stream order) into 1st, 2nd, 3rd, 4th, and 5th order and the lengths of streams in each order were quantified. The streams were separated into $10-\mathrm{m}$ pixels and a random generator selected pixels in each stream order for sampling sediment and monitoring flood-plain and channel change. The number of sites selected for each stream order was based on the length of each order as well as the propensity for streambank erosion. The propensity for streambank erosion was determined after a reconnaissance of streambank erosion in the watershed. In addition, the channel sites selected for analysis were inspected in the field to determine whether the site was 


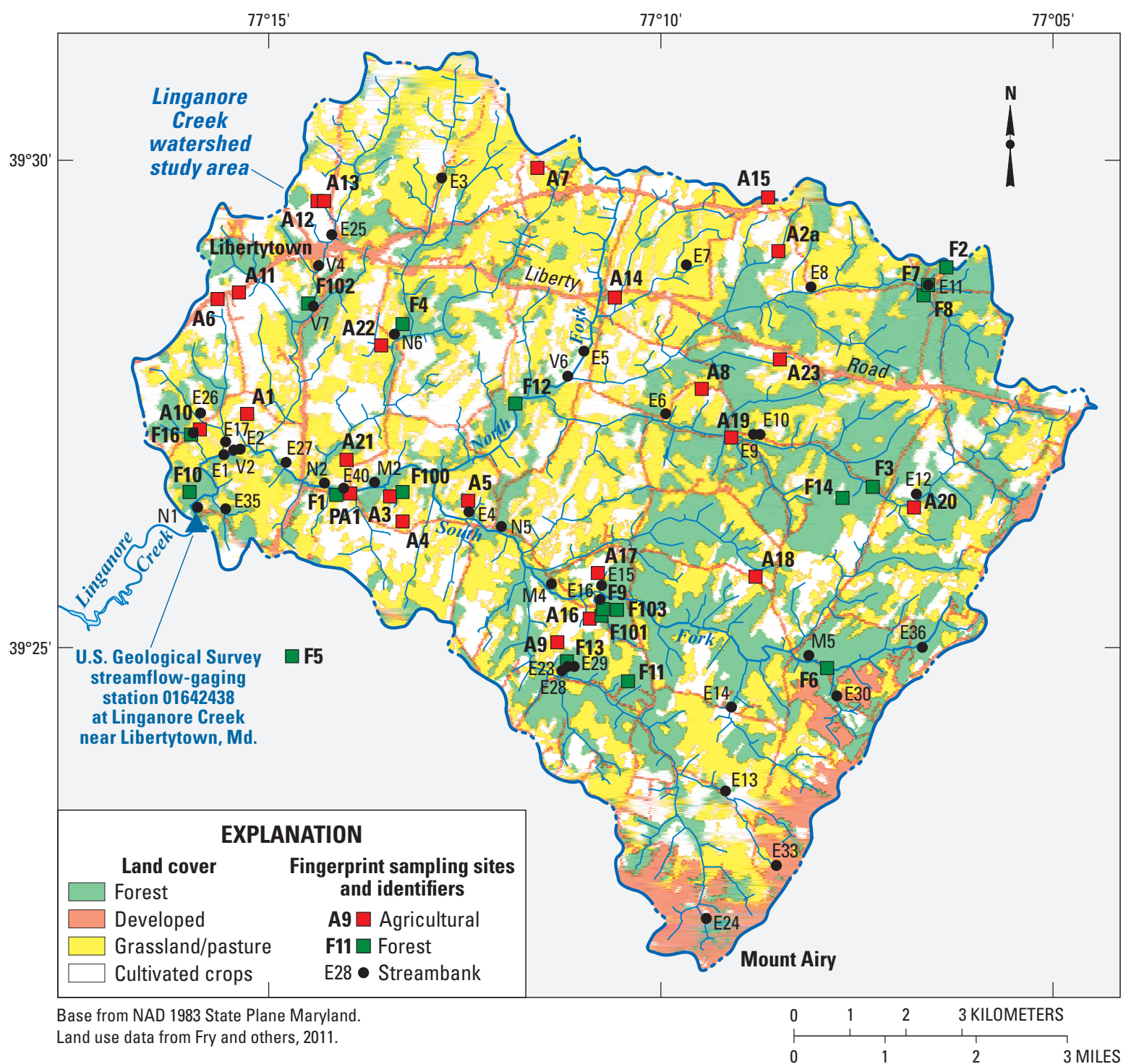

Figure 2. Location of sampling sites for sediment fingerprinting analysis, Linganore Creek watershed study area, Frederick and Carroll Counties, Maryland.

representative of typical stream conditions in the Linganore Creek watershed. Sites that were structurally modified such as being armored with rip-rap were not selected.

Soil samples for source analysis from agriculture and forested areas were collected from approximately the top 1.0 centimeter $(\mathrm{cm})$ of the soil surface with a plastic hand shovel. To account for variability in the tracer properties at agriculture and forested sites, sediment was collected across transects $(100 \mathrm{~m}$ by $30 \mathrm{~m})$ and composited into one sample. To obtain a representative sample of the streambanks, the surface of the exposed streambanks (approximately $1 \mathrm{~cm}$ ) was sampled vertically from the bottom to the top of the bank face. Three to five transects spaced $10 \mathrm{~m}$ apart along the stream reach were sampled and composited into one sample.

\section{Laboratory Analyses for Sediment Fingerprinting}

Agriculture, forest, and streambank samples were taken back to the USGS Baltimore, Maryland laboratory, dried at 60 degrees Celsius $\left({ }^{\circ} \mathrm{C}\right)$, and disaggregated with a mortar and pestle, wet sieved through a $63-\mu \mathrm{m}$ polyester sieve, and dried at $60{ }^{\circ} \mathrm{C}$. Sample dry weights before and after sieving were recorded to determine the percentage of sand in the samples.

The fine part (silt and clay; less than $63 \mu \mathrm{m}$ in diameter) of suspended sediment, upland, and channel corridor samples were sent to the USGS National Research Program (NRP) laboratories in Reston, Va. for elemental analyses and stable isotope analyses (table 1). At the USGS-NRP laboratory, the samples were analyzed for 19 elements (table 1). All samples 
were analyzed using inductively coupled plasma-optical emission spectrometry (ICP-OES) and inductively coupled plasmamass spectrometry (ICP-MS) after microwave-assisted multiacid digestion (a mixture of nitric and hydrofluoric acids). Standard reference soil (NIST2709, San Joaquin Soil) and blanks were digested in each round of microwave digestion. The average blank value was subtracted from all sediment and reference samples for each element. Only elements with measured concentrations within 10 percent of the published value for NIST2709 are reported. Specific details regarding this method can be found in Noe and Hupp (2005).

Samples were analyzed for the ratios of the stable isotopes of carbon and nitrogen $\left({ }^{13} \mathrm{C} /{ }^{12} \mathrm{C},{ }^{15} \mathrm{~N} /{ }^{14} \mathrm{~N}\right)$ and total carbon and total nitrogen (TC and TN) at the USGS Reston Stable Isotope Laboratory (RSIL) (table 1). Samples were first processed to remove inorganic carbon using hydrogen chloride ( $\mathrm{HCl})$ vapor digestion (Hedges and Stern, 1984); then total organic carbon (TOC) was measured. Methods for analysis are described on the RSIL web site (http://isotopes.usgs.gov; accessed April 5, 2014)/. The relative carbon isotopic results for the sample, $\delta^{13} \mathrm{C}$, are reported in per mil relative to Vienna Pee Dee Belemnite (VPDB) and normalized on a scale so that the relative carbon isotope ratios of $\mathrm{L}-\mathrm{SVEC} \mathrm{Li}_{2} \mathrm{CO}_{3}$ (lithium carbonate reference material prepared by $\mathrm{H}$. Svec) and NBS $19 \mathrm{CaCO}_{3}$ (National Bureau of Standards Reference Material 19 for calcium carbonate) are -46.6 and +1.95 per mil, respectively (Coplen and others, 2006). Nitrogen isotope ratios, $\delta^{15} \mathrm{~N}$, also reported in per mil, are expressed relative to $\mathrm{N}_{2}$ in air using several internationally distributed isotopic reference materials, as discussed in Révész and Qi (2006). The 2-sigma uncertainty for both $\delta^{13} \mathrm{C}$ and $\delta^{15} \mathrm{~N}$ analysis is plus or minus 0.50 per mil. The total number of tracers analyzed from the USGS laboratories was 23.

The size distribution of the less than $63-\mu$ sample was determined at the USGS NRP laboratory in Reston, Va., using laser diffraction (LISST-100X with mixing chamber) (Pedocchi and Garcia, 2006). Sediment samples were prepared for size distribution analysis by disaggregating the sample in a sodium hexametaphosphate solution that was sonicated for 5 minutes and shaken for 16 hours, and then analyzed on the LISST-100X to determine the median particle size $\left(\mathrm{D}_{50}\right)$ (Wolf and others, 2011). A mass of 20 milligrams (mg) was used for size analysis. Median values $\left(\mathrm{D}_{50}\right)$ of the sediment that are less than $63 \mu \mathrm{m}$ are reported in the LISST software. The smallest size class determined by this protocol is less than $1.56 \mu \mathrm{m}$.
Table 1. List of elements used as tracers to identify the sources of fine-grained sediment.

[ICP-OES, inductively coupled plasma-optical emission spectrometry; ICPMS, inductively coupled plasma-mass spectrometry; $\mathrm{mg} / \mathrm{g}$, milligrams per gram; $\mu \mathrm{g} / \mathrm{g}$, micrograms per gram; \%o, per mil; $\%$, percent]

\begin{tabular}{|c|c|c|}
\hline Element & Abbreviation & $\begin{array}{c}\text { Unit of } \\
\text { measurement }\end{array}$ \\
\hline \multicolumn{3}{|c|}{ Tracer measured from ICP-OES and ICP-MS analysis ${ }^{1}$} \\
\hline Aluminum & $\mathrm{Al}$ & $\mathrm{mg} / \mathrm{g}$ \\
\hline Antimony & $\mathrm{Sb}$ & $\mu \mathrm{g} / \mathrm{g}$ \\
\hline Arsenic & As & $\mu \mathrm{g} / \mathrm{g}$ \\
\hline Boron & B & $\mu \mathrm{g} / \mathrm{g}$ \\
\hline Cadmium & $\mathrm{Cd}$ & $\mu \mathrm{g} / \mathrm{g}$ \\
\hline Calcium & $\mathrm{Ca}$ & $\mathrm{mg} / \mathrm{g}$ \\
\hline Cobalt & Co & $\mu \mathrm{g} / \mathrm{g}$ \\
\hline Copper & $\mathrm{Cu}$ & $\mu \mathrm{g} / \mathrm{g}$ \\
\hline Iron & $\mathrm{Fe}$ & $\mathrm{mg} / \mathrm{g}$ \\
\hline Lead & $\mathrm{Pb}$ & $\mu \mathrm{g} / \mathrm{g}$ \\
\hline Lithium & $\mathrm{Li}$ & $\mu \mathrm{g} / \mathrm{g}$ \\
\hline Magnesium & $\mathrm{Mg}$ & $\mathrm{mg} / \mathrm{g}$ \\
\hline Manganese & $\mathrm{Mn}$ & $\mu \mathrm{g} / \mathrm{g}$ \\
\hline Molybdenum & Mo & $\mu \mathrm{g} / \mathrm{g}$ \\
\hline Nickel & $\mathrm{Ni}$ & $\mu \mathrm{g} / \mathrm{g}$ \\
\hline Phosphorus & $\mathrm{P}$ & $\mathrm{mg} / \mathrm{g}$ \\
\hline Potassium & $\mathrm{K}$ & $\mathrm{mg} / \mathrm{g}$ \\
\hline Titanium & $\mathrm{Ti}$ & $\mathrm{mg} / \mathrm{g}$ \\
\hline Vanadium & $\mathrm{V}$ & $\mu \mathrm{g} / \mathrm{g}$ \\
\hline Element/isotope & Abbreviation & $\begin{array}{c}\text { Unit of } \\
\text { measurement }\end{array}$ \\
\hline \multicolumn{3}{|c|}{ Tracer measured from stable isotope analysis ${ }^{2}$} \\
\hline Total organic carbon & TOC & $\%$ \\
\hline $\begin{array}{l}\text { Stable isotopic total } \\
\text { carbon }\end{array}$ & $\delta^{13} \mathrm{C}$ & $\%$ \\
\hline Nitrogen & $\mathrm{N}$ & $\%$ \\
\hline $\begin{array}{l}\text { Stable isotopic } \\
\text { nitrogen }\end{array}$ & $\delta^{15} \mathrm{~N}$ & $\%$ \\
\hline
\end{tabular}

${ }^{1}$ Analyzed at the U.S. Geological Survey National Research Program Laboratory in Reston, Va.

${ }^{2}$ Analyzed at the U.S. Geological Survey Reston Stable Isotope Laboratory in Reston, Va. 


\section{Statistical Methods}

Several analytical and statistical steps were used to determine which tracers were most significant in defining sediment sources (fig. 3) as follows:

1. Determine if there are outliers for each tracer in each source type.

2. Test if tracers in each source group need to be corrected for size differences between the source samples and the fluvial sample.

3. Test if tracers in each source group need to be corrected for organic content between the source samples and the fluvial sample.

4. Perform a bracket test of size- and organic-corrected fluvial and source samples for each tracer.

5. Determine the optimum number of tracers that discriminate among the sources using stepwise discriminant function analysis (DFA).

6. Pairwise Mahalanobis Distance Statistic.

7. Identify source percentages using an unmixing model on the final set of tracers.

Outlier test for each tracer in each source type

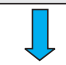

Size correction test of tracers compared to median grain size of fines $\left(D_{50}\right)$

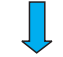

Organic correction test of tracers compared to Carbon (C)

Bracket test

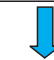

Stepwise Discriminant Function Analysis

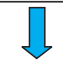

Mahalanobis Distance Statistic

Final source apportionment using an unmixing model

Figure 3. Outline of statistical operations used in determining sediment sources using the sediment fingerprinting approach.

\section{Outlier Test}

The presence of outliers can lead to errors in data analysis and statistical conclusions (Helsel and Hirsch, 1997). The first step in the statistical procedure was to remove outliers. In each source group, each tracer was tested to determine if it had a normal distribution using the Shapiro-Wilk test at a 95-percent confidence interval $(\mathrm{Ho}=$ samples are random and come from a normal distribution). All variables that were not normally distributed were tested again for normality after transformation using a log, power, square root, cube root, inverse, and inverse square root function (Helsel and Hirsch, 1997). The best transformation for normality was selected (if necessary aided by visual analysis of histograms), and the tracers were transformed. The average and standard deviation within each source group for each transformed tracer was determined. If the tracer value for a given source sample exceeded three times the standard deviation more or less than the average value, this sample was considered an outlier and the entire sample was removed (Wainer, 1976).

\section{Correcting Source Tracers for Sediment Size and Organic Content Variability}

The property of a sediment tracer not only depends on source material but on grain size and organic content (Horowitz, 1991; Collins and others, 2010). As sediment is eroded and transported through the watershed over time, grain size may change. Generally, sediment delivered out of a watershed has a finer grain size compared to the source areas (Walling, 2005). Finer grain sizes can have greater surface area than coarser grain sizes. The finer grain sizes have potentially more area to sorb constituents and have a higher tracer activity. Conversely, iron oxides that develop on coarser sediment in the silt range may also contain more sites for constituents to sorb on to and can have higher concentrations. Organic matter on sediment can also become sites for sorption of tracers.

To assure that tracers from sediment sources are comparable to tracers in fluvial sediment, based on grain size and organic content, a regression analysis was performed to determine if a tracer's property in each source group was significantly related to grain size and (or) organic content. This test was developed with assistance from Professor Desmond Walling (Desmond Walling, University of Exeter, UK, written commun., March 23, 2012). The LISST analyzed grain sizes for samples that had already been sieved to less than $63 \mu \mathrm{m}$ and provided the median grain size $\left(\mathrm{D}_{50}\right)$ of that size range for each sample analyzed. TOC was used to determine the organic content of the source samples and fluvial samples. For each source group, linear regression was used to determine if the relation of $\mathrm{D}_{50}$ or TOC to a given tracer's concentration was significant. The $\mathrm{D}_{50}$ was corrected first and then values were corrected for TOC. An example of how the $\mathrm{D}_{50}$ correction was applied is shown in figure 4 .

Guidelines used to determine if the relation of $\mathrm{D}_{50}$ or TOC to a given tracer's concentration is significant included 


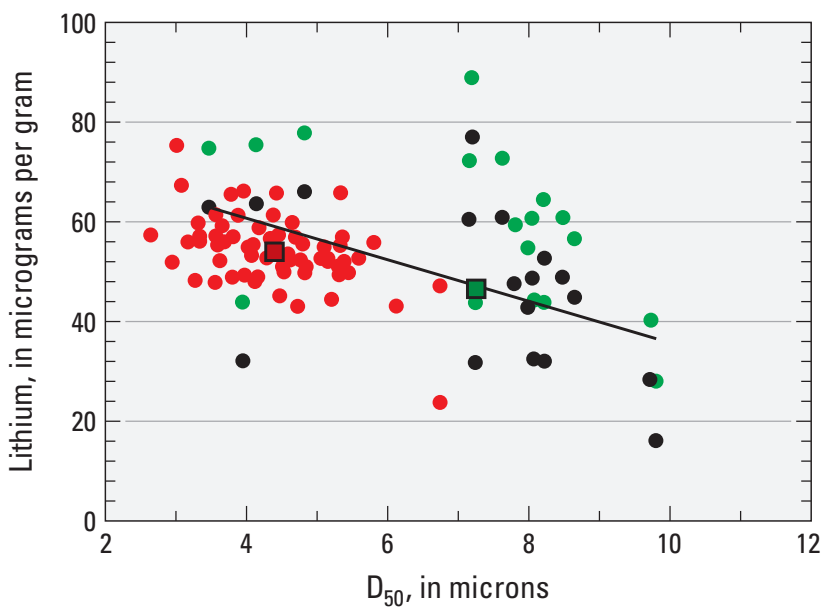

EXPLANATION

- Agriculture samples

— Regression of agriculture samples

- Fluvial samples

- Corrected agriculture samples

- Fluvial mean

- Agriculture mean

$D_{50}$ Median grain size of fine sediment

Figure 4. Example of how the size-correction factor is applied to a source group. In this example, agriculture sample size $\left(\mathrm{D}_{50}\right)$ was regressed against the tracer lithium (Li). The line of best fit of agriculture $D_{50}$ and agriculture lithium is negative. The concentration of lithium in the agriculture samples deceases as size $\left(D_{50}\right)$ increases. The average fluvial $D_{50}$ is finer than the average agriculture $D_{50}$. To correct for the differences in size, lithium should be adjusted to be higher. $\left[\mathrm{D}_{50^{\prime}}\right.$, median grain size of fine sediment.]

determining that the slope of the regression line is significant $(\mathrm{p}<0.05)$ and the residuals were normally distributed. If the slope of the regression was significant, the residuals of the regression equation were tested to see if they are independent and followed a normal distribution. The Shapiro-Wilk test $(\mathrm{Ho}=$ samples are random and come from a normal distribution) was used to determine that the residuals followed a normal distribution. Plots of residuals compared to predicted values as well as histograms of the residuals were also used to determine if the regression model was reasonable. In a plot of residuals compared to predicted values, a regression model is considered to be reasonable where the residuals show no curvature or changing variance (Helsel and Hirsch, 1997).

The steps used to determine the best regression model were: (1) determine if the relation of non-transformed $\mathrm{D}_{50}$ and TOC compared to each source group's tracer concentration is significant; (2) if selected tracers did not show a significant relation, then $\mathrm{D}_{50}$ and TOC were transformed using a log, power, square root, cube root, inverse, and inverse square root function. The transformed $\mathrm{D}_{50}$ and TOC were then regressed against each source group's tracer concentration to find the best regression model; (3) if after this step was completed, selected tracers did not show a significant relation to $\mathrm{D}_{50}$ or TOC, then a source group's tracer was transformed using a log, power, square root, cube root, inverse, and inverse square root. The transformed tracers in each source group were regressed against all possible combinations of transformed $\mathrm{D}_{50}$ and TOC (including untransformed) and the optimum regression model was selected. If no relation was found with $\mathrm{D}_{50}$ or TOC, a correction factor was not applied. The Tracers $\delta^{13} \mathrm{C}$, $\delta^{15} \mathrm{~N}$, and $\% \mathrm{~N}$ are affected by the relative proportions of different kinds of organic matter in the sample, not the total organic matter content (Carol Kendall, USGS, written/oral commun., June 27, 2013). The tracers, $\delta^{13} \mathrm{C}, \delta^{15} \mathrm{~N}$, and $\mathrm{N}$ were not corrected by TOC.

If the regression model of a source group's tracer compared to $\mathrm{D}_{50}$ was determined to be significant, then a correction factor was applied to the tracer as follows:

$$
C_{n}=\left\{T i_{i}-\left[\left(D_{50_{n}}-F D_{50}\right) * m\right]\right\}^{\wedge}
$$

where

$$
\begin{array}{cc}
C_{n}= & \text { untransformed tracer after size correction; } \\
T i_{i} & =\text { original value of tracer }(i) \text { (normalized) in } \\
& \text { source group }(n) ; \\
D_{50_{n}}= & \text { the mean } D_{50} \text { of samples in source }(n) \text { (if } \\
& \text { necessary transformed for normality); } \\
F D_{50} \quad= & \text { the mean } D_{50} \text { of fluvial samples (if } \\
& \text { necessary transformed for normality as the } \\
& \left.D_{50} \text { samples in source }[n]\right) ; \\
m \quad & \text { slope of regression line of tracers in source } \\
& \text { group }(n) \text { compared to } D_{50} \text { of source group } \\
& (n) \text { if necessary } D_{50} \text { is transformed for } \\
& \text { normality); and } \\
= & \text { if the tracer is normalized by a transform, } \\
& \text { the final corrected tracer is untransformed. }
\end{array}
$$

If the regression model of a source group's tracer compared to TOC was determined to be significant, then a correction factor was applied to the tracer as follows:

$$
C_{o}=\left\{T i_{i(n)}-\left[\left(C S_{n}-C F\right)^{*} m\right]\right\}^{\wedge}
$$

where

$$
\begin{aligned}
& C_{o}=\text { untransformed tracer after organic } \\
& \text { correction; } \\
& T i_{i(n)} \quad=\text { original value of tracer }(i) \text { (if necessary } \\
& \text { transformed for normality) in source group } \\
& (n) \text {; } \\
& C S_{n} \quad=\text { average carbon content of source group (n) } \\
& \text { (if necessary transformed for normality); } \\
& C F \quad=\text { average carbon content of fluvial samples }
\end{aligned}
$$


(if necessary transformed by the same transformation as the TOC samples in source $(n)$;

$m$ $=$ slope of the regression line of tracers in source group $(n)$ (if necessary tracers are transformed for normality) compared to TOC of source group $(n)$ (if necessary TOC is transformed for normality); and

$\wedge \quad=$ if the tracer is normalized by a transform, the final corrected tracer is untransformed.

When predicting the size-correction factor, it is important that the results are unbiased. If a non-linear model is used, a bias in the estimation can occur (Koch and Smillie, 1986). The bias occurs when tracers that are transformed are then corrected using equations 1 and 2 and then untransformed. Bias correction factors $(\hat{\boldsymbol{B}})$ were applied to the corrected, untransformed tracer concentrations only for those tracers that were transformed for normality prior to correction. If $\mathrm{D}_{50}$ or TOC were transformed for normality prior to use in the determination of correction factors but tracer concentration was not transformed, no bias correction was required. Bias correction factors $(\hat{\boldsymbol{B}})$ were determined by using the transformed tracer concentration per the equations given in table 2 (Stuart and Ord, 1991). The size- or organic-corrected tracer concentration is divided by $\hat{\boldsymbol{B}}$ to get the final untransformed tracer value.

Table 2. Equations used to correct for bias in untransforming the tracers.

$[\hat{\boldsymbol{B}}$, the bias correction factor; $f(y)$, the transformed value of the tracer; $\mathrm{D}_{50}$, the median grain size of the sediment; $\bar{x}_{S}$, the average value of all transformed $\mathrm{D}_{50}$ or total organic carbon (TOC) for a given sediment source; $\bar{x}_{F}$, the average value of the transformed $\mathrm{D}_{50}$ for the fluvial samples; $\hat{b}$, is the slope of the line of best fit; $\hat{\sigma}_{\hat{b}}^{2}$, is the standard error of the regression of $\mathrm{D}_{50}$ or TOC compared to tracers; exp, exponential]

\begin{tabular}{cc}
\hline Transformation & $\hat{\boldsymbol{B}}$ \\
\hline Squared & $1+\frac{1}{8}\left[f(y)-\left(\bar{x}_{S}-\bar{x}_{F}\right) \hat{b}\right]^{-2}\left(\bar{x}_{S}-\bar{x}_{F}\right)^{2} \hat{\sigma}_{\hat{b}}^{2}$ \\
Square root & $1+\left[f(y)-\left(\bar{x}_{S}-\bar{x}_{F}\right) \hat{b}\right]^{-2}\left(\bar{x}_{S}-\bar{x}_{F}\right)^{2} \hat{\sigma}_{\hat{b}}^{2}$ \\
Cube root & $1+3\left[f(y)-\left(\bar{x}_{S}-\bar{x}_{F}\right) \hat{b}\right]^{-2}\left(\bar{x}_{S}-\bar{x}_{F}\right)^{2} \hat{\sigma}_{\hat{b}}^{2}$ \\
Inverse & $1+\left[f(y)-\left(\bar{x}_{S}-\bar{x}_{F}\right) \hat{b}\right]^{-2}\left(\bar{x}_{S}-\bar{x}_{F}\right)^{2} \hat{\sigma}_{\hat{b}}^{2}$ \\
\hline $\begin{array}{c}\text { Inverse square } \\
\text { root } \\
\text { Log }\end{array}$ & $1+3\left[f(y)-\left(\bar{x}_{S}-\bar{x}_{F}\right) \hat{b}\right]^{-2}\left(\bar{x}_{S}-\bar{x}_{F}\right)^{2} \hat{\sigma}_{\hat{b}}^{2}$ \\
\hline & $10^{\wedge}\left[\left(\bar{x}_{S}-\bar{x}_{F}\right)^{2} \hat{\sigma}_{\hat{b}}^{2} / 2\right]$ \\
\hline
\end{tabular}

\section{Bracket Test}

A requirement of sediment fingerprinting is that the fluvial tracers must be conservative and not change during transport from the source to the sampling point. Consequently, the next step in the statistical analysis was determining that for a given tracer, the fluvial samples were within the range of the equivalent values obtained for the potential sources (Gellis and Walling, 2011 ) (fig. 3). The bracket test is an important prerequisite before further statistical analyses are performed. Any tracers that did not satisfy this constraint within measurement error (10 percent of each fluvial sample's tracer value) were considered to be non-conservative and were removed from further consideration. The bracketing test was performed on tracers after the particle size and organic correction factors were applied.

\section{Stepwise Discriminant Function Analysis}

Collins and Walling (2002) and Collins and others (1997) have suggested that a composite of several tracers provides a greater ability to discriminate between sources than a single tracer. To create the optimal group of tracers, a stepwise DFA was used to select tracers after size and organic corrections were applied (fig. 3). This procedure assumes normality among the variables being analyzed; thus, all variables used in the DFA were tested for normality using the Shapiro-Wilk test $(\mathrm{Ho}=$ samples are random and come from a normal distribution). All variables that were not normally distributed at a 95-percent confidence interval were tested again for normality after transformation using a log, power, square root, cube root, inverse, and inverse square root function (Helsel and Hirsch, 1997).

The best transformation for normality was selected (if necessary) and stepwise DFA was performed on the normalized data. Stepwise DFA incrementally identifies which tracers significantly contribute to correctly differentiating the sediment sources and rejects variables that do not contribute based on the minimization of the computed value of the variable Wilks' lambda (Collins and others, 1997). A lambda close to 1.0 indicates that the means of all tracers selected are equal and cannot be distinguished among groups. A lambda close to zero occurs when any two groups are well separated (within group variability is small compared to overall variability). Thus, the model selects a combination of tracers that provide optimal separation, meaning that no better separation can be achieved using fewer or more tracers. The statistical program Statistical Analysis System (SAS) was used in stepwise DFA (SAS Institute, 2004). A probability value of 0.01 was used in stepwise DFA.

Another requirement of sediment fingerprinting is that the final set of tracers determined from stepwise DFA can correctly differentiate each source type. The pairwise Mahalanobis distance is a measure of the distance between groups and takes into account the covariance among the variables in calculating distances (Rao, 1965). The Mahalanobis distance has been used in other sediment-source studies 
(Karlin, 1980; Minella and others, 2008; Poulenard and others, 2009) and was used in this analysis to verify that the set of transformed tracers determined from stepwise DFA can correctly distinguish each source type (fig. 3). A probability value of 0.05 was used in the Mahalanobis distance statistic test. The pairwise Mahalanobis distance statistic was run on the final set of normalized tracers determined from stepwise DFA. If the final set of tracers is not able to differentiate between any two sources, a decision is made to combine the sources into one source type. An example would be combining agriculture and forest into one source dataset called uplands. Stepwise DFA and the pairwise Mahalanobis distance statistics are then repeated on the new dataset.

\section{Identification of Source Percentages}

The final step in the statistical analysis was determining the significant sources of sediment using an unmixing model (fig. 3; equations 3,4 , and 5; modified from Collins and others, 2010). The set of tracer values that are determined from the stepwise DFA are used in the unmixing model but with the particle size and organic correction factors applied. The unmixing model does not use data transformed for normality but it does use the values that have been adjusted for $\mathrm{D}_{50}$ and TOC.

$$
\sum_{i=1}^{n}\left\{\left[C_{i}-\left(\sum_{s=1}^{m} P_{s} S_{s i}\right)\right] / C_{i}\right\}^{2} W_{i}
$$

and

$$
\sum_{s=1}^{n} P_{s}=1
$$

where

$$
\begin{aligned}
& C_{i}=\text { concentration of tracer property }(i) \text { in the } \\
& P_{s} \quad=\text { the optimized percentage contribution from } \\
& \text { source category }(s) \text {; } \\
& S_{s i} \quad=\text { mean concentration of tracer property }(i) \\
& W_{i} \quad=\text { tracer discriminatory weighting; } \\
& n=\text { number of fingerprint properties that make } \\
& \text { up the optimum composite fingerprint; and } \\
& m \quad \text { number of sediment source categories. }
\end{aligned}
$$

Collins and others (2010) applied the particle size and organic corrections factors directly in the unmixing model. In this modified version (equation 3), the set of tracer values that were determined from the stepwise DFA were used in the unmixing model with the particle size and organic correction factors applied. The unmixing model was written in the programming language Python.

The unmixing model iteratively tests for the lowest error value using all possible source percentage combinations. A $P_{s}$ step of 0.01 is used in the source computations. The tracer discriminatory weighting value, $W_{i}$, is a weighting used to reflect tracer discriminatory power in equation 3 (Collins and others, 2010). This weighting is based on the relative discriminatory power of each individual tracer provided by the results of the stepwise DFA and ensures that tracers that have a greater discriminatory power are optimized in the unmixing model solutions. The weighting for each tracer that passed the stepwise DFA test was determined as follows:

$$
W_{i}=\frac{P_{i}}{P_{o p t}}
$$

where

$$
\begin{aligned}
& W_{i} \quad=\text { tracer discriminatory weighting for tracer } \\
& \text { (i); } \\
& P_{i} \quad=\text { percent of source type samples classified } \\
& \text { correctly using tracer }(i) \text {. The percent of } \\
& \text { source type samples classified correctly is } \\
& \text { a standard output from the DFA statistical } \\
& \text { results; and } \\
& P_{o p t} \quad=\text { the tracer that has the lowest percent of } \\
& \text { sample classified correctly. Thus a value } \\
& \text { of } 1.0 \text { has low power of discriminating } \\
& \text { samples. }
\end{aligned}
$$

Sediment apportioned to streambanks, agriculture, and forest is determined for each sample, the sampled storm event, and for the entire study period. The sediment sources of each sample during a storm event are averaged to describe the sediment sources for that storm event. However, each sample may have been collected for different flow and sediment conditions during the event, therefore, using the average of sources during the event may not be the best method to determine the sediment sources for that event. For example, the time interval represented by a sample may represent the majority of sediment transported for that event and therefore may be a more important sample in describing sediment sources for that event. To include the importance of samples collected during periods of high sediment loading, the sediment sources determined for each sample were weighted by the total amount of sediment transported for that event (storm weighted) using the following equation:

$$
S_{v j}=\sum_{i=1}^{n}\left[S A_{v i} *\left(\frac{S L_{i}}{S L_{t j}}\right)\right]
$$

where

$$
\begin{aligned}
S_{v j}= & \text { storm-weighted source allocation for source } \\
& (v) \text { (streambanks, agriculture, or forest ) } \\
& \text { (in percent) and event }(j) ;
\end{aligned}
$$




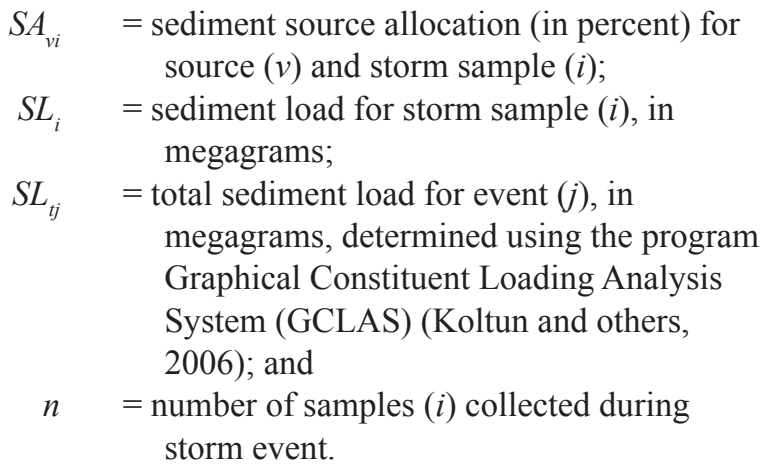

As previously discussed, because of mass constraints, a storm sample represents one instantaneous time or several times on the storm hydrograph. To determine a sediment load for a given sample $\left(S L_{i}\right)$, a time interval was assigned for each sample. The time interval for each sample was midway between the previous and next sample. The first sample was assigned a time to the nearest 15 -minute interval before that sample and midway to the next sample time. The last sample was assigned a time midway to the previous sample time and to the nearest 15 -minute interval after that sample. Fifteenminute intervals were selected because this was the frequency of calculated discharges. Samples were never collected at intervals less than 15 minutes. Each sample's time interval was input into the program GCLAS and a sediment load (megagrams, or $\mathrm{Mg}$ ) was determined for that time interval. The sum of sediment loads for each interval is the total sediment load for the event $\left(S L_{t j}\right.$ in equation 6).

For the entire study period, sediment-source allocation is presented two ways - by averaging the sources for all storms, and by weighting each storm's source allocation (stormweighted source percentage) $\left(S_{v j}\right.$ in equation 6$)$ by the total sediment load transported for that event divided by the sum of fine-grained suspended-sediment transported for all events (total load weighted). One event may transport the majority of sediment during the study period and thus may be a more important event in describing sediment sources. The sediment source weighting for the entire study period (total load weighted percentage) was determined using the equation:

$$
T S_{v j}=\sum_{j=1}^{m}\left[S_{v j} *\left(\frac{S L_{t j}}{S L_{p}}\right)\right]
$$

where

$$
\begin{aligned}
& T S_{v j} \quad=\text { period of study-weighted sediment-source } \\
& \text { allocation for source }(v) \text { (streambanks, } \\
& \text { agriculture, or forest); } \\
& S_{v j} \quad=\text { sediment-source allocation for source }(v) \\
& \text { (streambanks, agriculture, or forest ) for } \\
& \text { event }(j) \text {; } \\
& S L_{t j} \quad=\text { total sediment load for event }(j) \text {, in } \\
& \text { megagrams; } \\
& m \text { = number of events during the study period }= \\
& 36 \text {; and }
\end{aligned}
$$

$$
S L_{p} \quad=\begin{gathered}
\text { total sediment load for } 36 \text { events, in } \\
\text { megagrams. }
\end{gathered}
$$

A similar approach to presenting sediment sources for an entire study period was used by Walling and others (1999) and Gellis and others (2009).

\section{Limitations and Uncertainty in Sediment Fingerprinting}

A Monte Carlo approach was used to quantify the uncertainty in the sediment fingerprinting results produced by the unmixing model (Collins and Walling, 2007). A Monte Carlo simulation was written in the programming language Python. The Monte Carlo simulation randomly removes one sample from each of the three source type groups and the unmixing model is run without these samples. The Monte Carlo simulation is run 1,000 times on each fluvial sample. For each of the 1,000 iterations, the average, and the minimum and maximum sediment-source percentage for each source are determined. The following was used to assess the robustness of the final set of source samples and tracers: (1) the difference between the final unmixing model sediment-source percentage results and the average of the 1,000 Monte Carlo sediment-source percentage results, and (2) the minimum and maximum source percentage results produced by the Monte Carlo simulation.

\section{Sediment Budget Measurements}

A sediment budget framework can be used to understand geomorphic processes of sediment erosion, transport, storage, delivery, and linkages among these elements that occur in a watershed (Leopold and others, 1966; Swanson and others, 1982; Gellis and others, 2012). The most basic form of the sediment budget equation is:

$$
I \pm \Delta S=O
$$

where

$$
\begin{aligned}
I & =\text { the sediment input; } \\
\Delta S & =\text { the change in sediment storage; and } \\
O & =\text { the sediment output. }
\end{aligned}
$$

Budgets can become quite complicated as multiple geomorphic elements are identified and linked to create a more accurate representation of sediment movement through a basin.

The sediment budget for the Linganore Creek watershed is for fine-grained sediment that is composed of silts and clay. The input and change in storage of sediment (in equation 8) were based on measurements made on upland land use/land covers of forest and agriculture, measurements made in the channel corridor (channel bed and banks, and flood plain), and a photogrammetric analysis of ponds. The output of sediment $(O$ in equation 8$)$ is determined using two approaches. The output is the difference in the mass input and storage of 
sediment determined from the sediment budget and the output is also the fine-grained suspended-sediment (in kilograms per year, or $\mathrm{kg} / \mathrm{yr}$ ) measured at the watershed outlet. The output determined from the sediment budget is considered an estimate and is compared to the fine-grained suspended sediment measured at the watershed outlet. Any difference that occurs between these two values is considered the error in the sediment budget.

The geomorphic elements shown in figure 5 were used to develop a sediment budget of fine-grained sediment. Erosion and deposition on the geomorphic elements was quantified using a variety of techniques. Changes in the channel bed (including channel bars) were quantified through monumented cross-sectional surveys. Bank erosion and deposition were quantified using bank pins. Flood-plain deposition was measured using clay pad artificial marker horizons. Upland rates of erosion were estimated using the Cesium-137 $\left({ }^{137} \mathrm{Cs}\right)$ technique. An accounting of the erosion and deposition of fine-grained sediment on each geomorphic unit was determined and converted to a mass rate $(\mathrm{kg} / \mathrm{yr})$ by multiplying the measurements (square centimeters per year, or $\mathrm{cm}^{2} / \mathrm{yr}$ ) by the bulk density (grams per cubic centimeter, or $\mathrm{g} / \mathrm{cm}^{3}$ ) on each geomorphic element and by the length (kilometer, or km) or area $\left(\mathrm{km}^{2}\right)$ of the geomorphic element. The final sediment budget was constructed and compared to the measured finegrained suspended sediment transported out of the basin.

\section{Fluvial Sediment Transport}

Sediment output ( $O$ in equation 8 ) is the fine-grained suspended-sediment load computed at the USGS Linganore Creek streamflow-gaging station (01642438), which is located at the outlet of the Linganore Creek watershed as defined in this study (fig. 1). During the period of study (August 1, 2008 to December 31, 2010) samples of suspended sediment were manually collected at various points in the cross section using the Equal Width Increment (EWI) method (Edwards and Glysson, 1999). During high flows, suspended sediment was collected using an automatic suspended-sediment pump sampler.

The automatic suspended-sediment sampler (ISCO, Inc.) is designed to pump samples into 24 separate 1 -L plastic bottles. The sampler contains a peristaltic pump to transport the sample from the stream to the sample bottle. The transfer line is purged by the sampler before and after each sample is collected. The timing of the 24 samples was pre-programmed to pump samples over the flood hydrograph. The intake for the automatic sampler was placed above the bed in the center of the channel, at an elevation equal to half the distance of the lowest bank height. Since the automatic sampler pumps water from a fixed point in the channel, a bias could exist in the suspended-sediment concentrations when compared to a cross-sectional, integrated sample. During medium flows, cross-sectional samples were collected using a DH-81 sampler. During selected high flows, samples were collected using a US D-74 isokinetic sampler deployed at the Old Annapolis Road bridge crossing located approximately one-half km upstream of the streamflow-gaging station. The suspended-sediment concentrations in samples collected with the DH-48 and D-74 isokinetic samplers were used to determine if the automatic sampler had any bias in its samples.

Suspended-sediment samples were sent to the USGS Kentucky Water Science Center Sediment Laboratory in Louisville, Ky. for analysis of suspended-sediment concentrations. Daily suspended-sediment loads were computed at Linganore Creek using the subdivision method (Porterfield, 1977) with the USGS software program GCLAS.

At the Linganore Creek gage, a nephelometer for measuring turbidity was installed from August 1, 2008 to September 30, 2009 and recorded turbidity readings every 15 minutes. Turbidity was recorded in Formazin Nephelometric Units (FNUs). Turbidity data was transformed into suspendedsediment concentration using an equation of the line of best-fit between turbidity and suspended-sediment concentration. In the program GCLAS, the following data are plotted with time on the computer screen: (1) the hydrograph for the period of

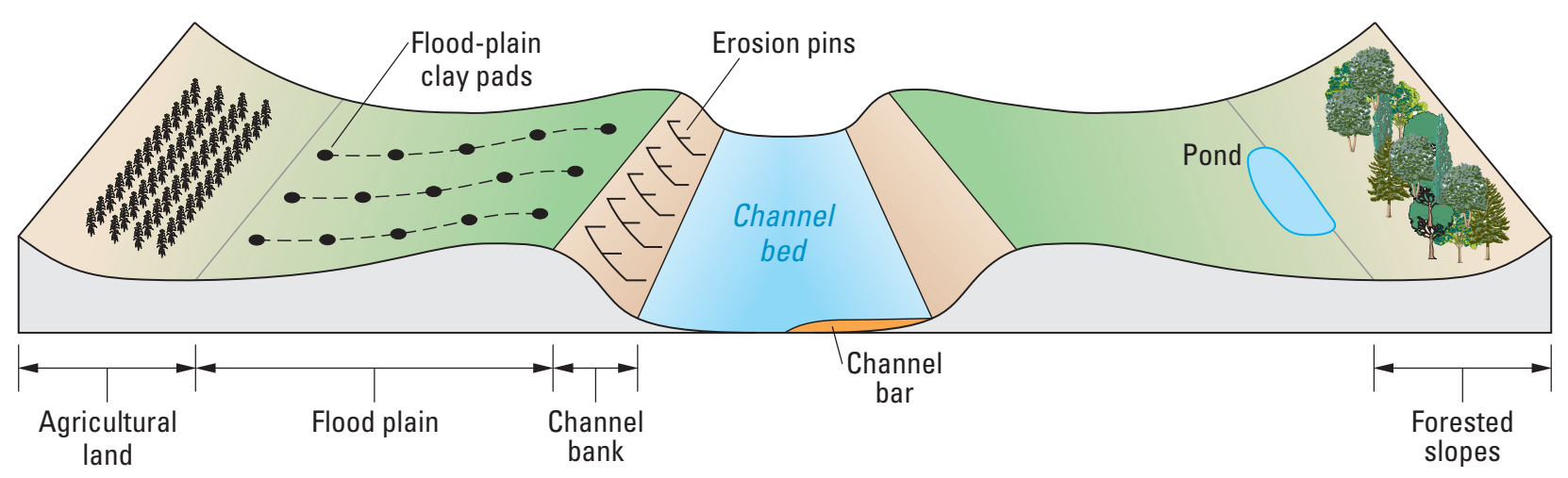

Figure 5. Schematic diagram showing the geomorphic elements where erosion and deposition were measured or estimated in Linganore Creek, Maryland. [The reach is not drawn to scale.] 
interest, (2) sampled suspended-sediment concentrations, and (3) a background curve of transformed values of turbidity expressed as suspended-sediment concentration (in milligrams per liter, or $\mathrm{mg} / \mathrm{L}$ ). These data enable the user to create a continual trace of suspended-sediment concentration. When it is determined that a satisfactory trace of suspended-sediment concentration has been developed, GCLAS computes the suspended-sediment load for each day of interest.

From October 1, 2009 to December 31, 2010, turbidity data were not available and missing periods of suspended-sediment concentration during runoff events were estimated using the relation between discharge and suspended-sediment concentration referred to as a sediment-transport curve (Glysson, 1987). The sediment-transport curve was constructed using data for the period of record. For missing periods of suspended-sediment concentrations during runoff events, the estimated values using the sediment-transport curve were put into GCLAS and used in the computation of suspended-sediment loads.

\section{Channel Bed Changes}

Twenty-three stream reaches that contain permanent cross sections were established in the Linganore Creek watershed to assess changes to the channel bed and channel bars during the period of study (fig. 6). Reaches that were typical of streamchannel morphology in the Linganore Creek watershed were selected based on a reconnaissance of streams in the basin, landowner permission, and existence of pre-existing monumented cross sections. Four reaches (V2, V4, V6, V7 in figure 6) had pre-existing monumented cross sections (Versar, 2002). Each reach contained between one and three permanent cross sections. Cross sections were established with monumented endpoints of steel bars driven into the flood plain or hillslopes on both sides of the channel. The cross sections were established in straight sections and meandering sections of the channel and were aligned perpendicular to the direction of the streamflow. The cross sections were initially surveyed between August 11, 2008 and July 22, 2009 and resurveyed between March 16, 2010 and December 24, 2010.

The width of the channel bed shown in figure 5 was determined in the field during the cross-sectional surveys. Sediment bars found in the channel were considered part of the channel bed. The initial channel survey and the resurvey were plotted and the cross-sectional area change (square meters, or $\mathrm{m}^{2}$ ) of the channel bed between the two surveys was determined.

Since the measurement period for each cross-sectional survey varied, to obtain an annual rate of bed erosion or deposition, each channel-bed measurement made was divided by the measurement period in days and multiplied by 365 . All bed changes were averaged for a reach, as follows:

$$
B R_{j}=\frac{\sum_{i=1}^{n}\left(\frac{B R_{i}}{N_{d}} * 365\right)}{n}
$$

where

$$
\begin{aligned}
& B R_{j} \quad=\text { net change in channel bed at reach }(j) \text {, in } \\
& \text { square centimeters per year; } \\
& B R_{i} \quad=\text { net change in channel bed at cross section } \\
& \text { (i), in square centimeters; } \\
& N_{d} \quad=\text { days between first and last channel surveys; } \\
& \text { and } \\
& n \quad=\text { number of channel beds measured at reach } \\
& (j) \text {. }
\end{aligned}
$$

To obtain channel bed changes for a particular stream order, all reaches for a particular stream order were averaged, as follows:

$$
B R_{(s)}=\left(\frac{\sum_{j=1}^{N} B R_{j}}{N}\right)
$$

where

$$
\begin{aligned}
& B R_{(s)} \quad=\text { net change in channel bed for stream order } \\
& (s) \text {, in square centimeters per year; } \\
& B R_{j} \quad=\text { net change in channel bed at reach }(j) \text {, in } \\
& \text { square centimeters per year; and } \\
& N \quad=\text { number of reaches }(j) \text {, in stream order }(s) \text {. }
\end{aligned}
$$

In parts of the channel with coarser sediment (coarse sand and gravel and larger), samples of the bed and bars were collected with a shovel to determine the percentage of silt and clay in the channel bed and bars. In parts of the channel bed with deposits of finer material (medium sand to silt and clay), a $10-\mathrm{cm}$ by $18-\mathrm{cm}$ polyvinyl chloride (PVC) tube was used to sample the sediment. Channel bed samples were taken back to the lab, dried at $60{ }^{\circ} \mathrm{C}$ for 24 to 48 hours or until dry. The samples were ground with a mortar and pestle and wet sieved through a $63-\mu \mathrm{m}$ sieve to remove particles that were sand size and larger. The remaining sediment was dried then weighed to determine the mass and percentage of silt and clay.

\section{Streambank Erosion and Deposition}

Bank erosion and deposition were measured by installing bank pins at all 23 surveyed cross sections and at an additional 27 cross sections that did not have a full cross-sectional survey. At each cross section, one to nine 1.2-m steel pins were installed normal to the bank face. Pin exposure was measured at the time of installation, annually, and at the end of the study. The total erosion or deposition at a bank face was determined by taking a weighted average of the pin measurements over the study period.

The weighted average was based on the length of bank that each pin represented. The top pin represented a bank length from the top of the bank to half the distance to the second pin. The bank length represented by each pin, from the second pin to the pin above the bottom pin, was determined as 


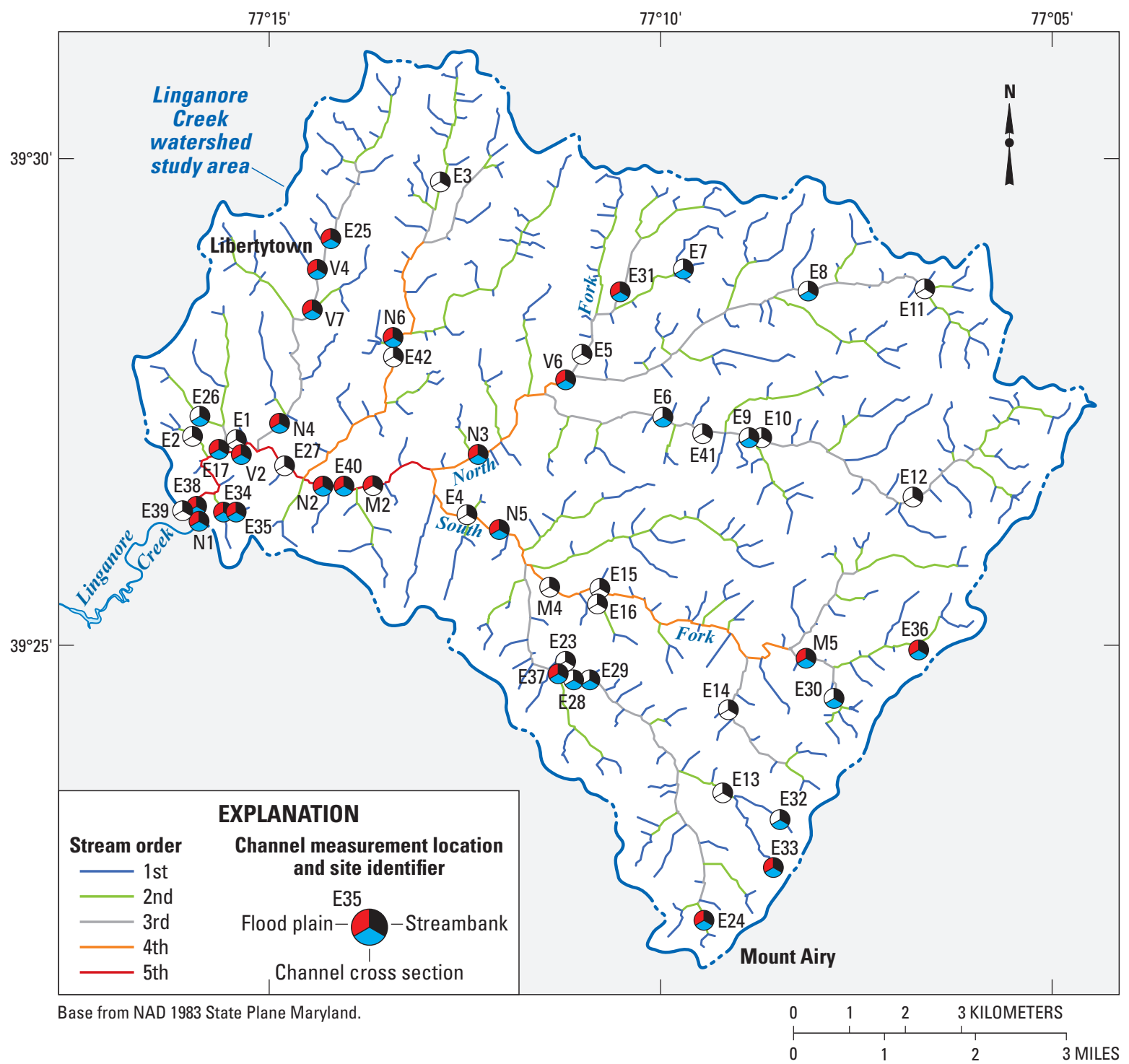

Figure 6. Location of channel measurements for cross sections, flood-plain deposition, and bank erosion in the Linganore Creek watershed study area, Frederick and Carroll Counties, Maryland.

half the distance to the pin above plus half the distance to the next pin down. The bank length represented by the bottom pin was half the distance to the pin above plus the distance to the bottom of the bank. The net change in the bank was determined as the bank length represented by each pin $(\mathrm{cm})$ divided by the total length of the bank $(\mathrm{cm})$ and summed, as follows:

$$
B K_{i}=\sum_{n}^{1}\left(\frac{D P_{n}}{B L}\right) * P T_{n}
$$

where

$$
\begin{aligned}
B K_{i} \quad= & \text { weighted average of bank erosion or } \\
& \text { deposition at selected bank face }(i) \text { over } \\
& \text { measurement period, in square centimeters; } \\
D P_{n} \quad= & \text { the part or length of the bank face measured } \\
& \text { with pin }(n), \text { in centimeters; }
\end{aligned}
$$

$$
\begin{aligned}
n & =\text { number of pins; } \\
B L & =\text { total length of the bank, in centimeters; and } \\
P T_{n} & =\text { the net change in pin }(n) .
\end{aligned}
$$

Since the measurement period for each bank face varied, to obtain an annual rate of bank erosion or deposition ( $\mathrm{kg} / \mathrm{yr})$, the net change for each bank face was divided by the measurement period in days and multiplied by 365 . The net change for all banks in a reach were then averaged to obtain a reach-averaged bank change, as follows:

$$
B k_{j}=\frac{\sum_{i=1}^{n}\left(\frac{B k_{i}}{N_{d}} * 365\right)}{n}
$$


where

$$
\begin{aligned}
& B k_{j}=\text { net change in banks at reach }(j) \text {, in square } \\
& \text { centimeters per year; } \\
& B k_{i} \quad=\text { the weighted average of bank erosion or } \\
& N_{d} \quad=\text { number of days of measurements; and } \\
& n=\text { number of bank faces measured at reach }(j) \text {. }
\end{aligned}
$$

To obtain bank erosion or deposition for a particular stream order, the net change in bank erosion for all reaches of a particular stream order was averaged. Since a bank is located on either side of a stream, the final value of bank changes for each stream order was multiplied by 2 . The equation used to determine bank erosion or deposition for a given stream order is:

$$
K_{r(s)}=2 *\left(\frac{\sum_{j=1}^{N} B K_{j}}{N}\right)
$$

where

$$
\begin{array}{cc}
K_{r(s)}= & \text { net change in streambanks for stream order } \\
& (s), \text { in square centimeters per year; and } \\
N \quad= & \text { number of reaches }(j), \text { in stream order }(s) .
\end{array}
$$

Bank erosion or deposition is commonly shown as centimeters per year $(\mathrm{cm} / \mathrm{yr})$. The net change of each bank $\left(\mathrm{cm}^{2} / \mathrm{yr}\right)$ was divided by the bank height $(\mathrm{cm})$ to obtain erosion or deposition per year (cm/yr), as follows:

$$
B k_{t(i)}=\left(\left(\frac{B K_{i}}{N_{d}}\right) / B_{h}\right) * 365
$$

where

$$
\begin{array}{cl}
B k_{t(i)} \quad & \text { bank erosion of bank }(i), \text { in centimeters per } \\
& \text { year; } \\
B K_{i} \quad= & \text { bank erosion or deposition at a selected } \\
& \text { bank face }(i) \text { over the measurement period, } \\
& \text { in square centimeters; } \\
N_{d} \quad= & \text { number of days of measurements; and } \\
B_{h} & =\text { bank height, in centimeters. }
\end{array}
$$

Cores were collected from the streambanks to determine dry bulk density. The plastic cores had lengths ranging from 2.0 to $8.2 \mathrm{~cm}$, diameters from 2.1 to $6.2 \mathrm{~cm}$, and volumes ranging from 17.3 to $220 \mathrm{~cm}^{3}$. The cores were driven flush into the streambanks. The sediment was dried at $60{ }^{\circ} \mathrm{C}$ for 48 hours or until dry, and weighed. The dry bulk density $\left(\mathrm{g} / \mathrm{cm}^{3}\right)$ is calculated as the dry mass of the sediment (grams, or g) divided by the core volume $\left(\mathrm{cm}^{3}\right)$.

Samples of the streambanks were collected by scraping the bank face with a hand shovel to determine the percentage of silt and clay. Samples were taken back to the lab, dried at $60{ }^{\circ} \mathrm{C}$ for 24 to 48 hours or until dry. The samples were ground with a mortar and pestle and wet sieved through a $63-\mu \mathrm{m}$ sieve to remove particles that were sand size and larger. The remaining sediment was dried and weighed to determine the mass and percentage of silt and clay. These samples were not used in the analysis of tracers.

\section{Flood-Plain Deposition}

Flood-plain deposition was measured using artificial marker layers (clay pads). The markers, powdered white feldspar clay approximately $20 \mathrm{~mm}$ in thickness, were placed over an area of about $0.5 \mathrm{~m}^{2}$ on the soil surface that had been cleared of organic detritus. The clay becomes a fixed plastic marker after absorption of soil moisture that permits accurate measurement of short-term net vertical accretion above the clay surface (Ross and others, 2004; Gellis and others, 2009). For each surveyed cross section, 6 to 10 clay pads were placed on different parts of the flood plain.

At the end of the study period, the clay pads were examined for depth of burial. Depth of burial was measured by coring the ground surface through the clay pads, and measuring the vertical depth of sediment above the artificial clay layer. At the end of the study period, many of the clay pads had been disturbed, possibly by livestock trampling and erosional processes, or could not be located, and therefore it was not feasible to determine the net flood-plain deposition at a cross section. A regression model was developed to estimate the response variable (flood-plain deposition in millimeters per day, or $\mathrm{mm} / \mathrm{d}$ ) using explanatory variables of: (1) drainage area of the measured reach $\left(\mathrm{m}^{2}\right)$, (2) elevation of the flood plain above the thalweg $(\mathrm{cm})$, and (3) distance of the clay pad from the channel edge $(\mathrm{cm})$ (Asselman and Middelkoop, 1995; Simm and Walling, 1998). The explanatory variables were tested for normality using the Shipiro-Wilk test at a probability set to 0.05 . If necessary, the explanatory variables were transformed using the log, inverse, squared, square root, or cube root transform (Helsel and Hirsch, 1997). The final set of explanatory variables for the regression model was selected using stepwise regression procedures in the statistical software package SAS (SAS Institute, 2004).

In forward stepwise regression, the explanatory variable having the highest explanatory power to the predicted variable (deposition) is entered into the regression model, and successively, the remaining explanatory variables are added one at a time to the model, as long as the F statistic p-value is below the specified $\alpha$. Forward selection was used with $\alpha=0.05$.

The regression equation was applied to each survey point on the flood plain for each cross section to obtain deposition at each survey point $(\mathrm{mm} / \mathrm{yr})$. The extent of the flood plain was determined at the time of the cross-sectional survey and was based on geomorphic features of topography, vegetation, and soil characteristics. The area of deposition $\left(\mathrm{cm}^{2} /\right.$ day) on the flood plain (both sides of the channel) for the period of study was determined by averaging deposition $(\mathrm{mm} / \mathrm{d})$ at adjacent survey points and multiplying by the length between points, and summing all values, as follows: 


$$
F_{n i}=\left(\sum_{1}^{n}\left[\frac{\left(P_{1}+P_{n+1}\right)}{2} / 10 *\left(L_{n+1}-L_{1}\right)\right]\right) * 365
$$

where

$$
\begin{array}{cc}
F_{n i} \quad=\text { estimated deposition on flood plain at a } \\
\text { surveyed cross section }(i) \text { for the period of } \\
& \text { study, in square centimeters per year; } \\
P \quad= & \text { estimated deposition, at survey point (from } \\
& 1 \text { to } n \text { ) using regression equation, in } \\
& \text { millimeters per day; and } \\
L \quad= & \text { station of survey point (from } 1 \text { to } n \text { ) on } \\
& \text { flood plain, in centimeters. }
\end{array}
$$

If more than one cross section was surveyed at the same reach, the modeled flood-plain deposition rates $\left(\mathrm{cm}^{2} / \mathrm{yr}\right)$ were averaged for that reach.

$$
F_{r j}=\frac{\sum_{i=1}^{n} F_{n i}}{n}
$$

where

$$
\begin{aligned}
& F_{r j} \quad=\text { estimated deposition on flood plain at a } \\
& F_{n i} \quad=\text { estimated deposition on flood plain at a } \\
& n \quad=\text { number of cross sections. }
\end{aligned}
$$

To obtain flood-plain deposition for a particular stream order, all reaches for a particular stream order were averaged, as follows:

$$
F_{r(s)}=\frac{\sum_{j=1}^{N} F_{r j}}{N}
$$

where

$$
\begin{aligned}
& F_{r(s)} \quad=\text { estimated deposition on flood plain for } \\
& F_{r j} \quad=\text { estimated deposition on flood plain for } \\
& N=\text { number of reaches. }
\end{aligned}
$$

The bulk density of the flood-plain sediment $\left(\mathrm{g} / \mathrm{cm}^{3}\right)$ was determined by taking a core of the accreted sediment at the pad (g). The cores were taken back to the lab, dried at $60{ }^{\circ} \mathrm{C}$ for 48 hours or until dry, and weighed. The mass of deposited material in the core $(\mathrm{g})$ was divided by the volume of the cored sediment $\left(\mathrm{cm}^{3}\right)$ to obtain the bulk density $\left(\mathrm{g} / \mathrm{cm}^{3}\right)$. The cores were also wet sieved for the percentage of silt and clay. If only a limited amount of mass was cored, the top $1-2 \mathrm{~cm}$ of the sediment on the ground surface adjacent to the clay pad was sampled by scraping the surface with a small plastic hand shovel and wet sieved for the percentage of silt and clay. The ground surface adjacent to the clay pad was assumed to correspond to deposition that occurred during the course of study.

\section{Upland Erosion Using Cesium-137}

The ${ }^{137} \mathrm{Cs}$ technique has been used worldwide to estimate soil loss and gain (Sutherland, 1989; Ritchie and McHenry, 1990; Bernard and others, 1998). ${ }^{137} \mathrm{Cs}$ is a by-product of above ground thermonuclear bomb testing and was released globally as fallout from the testing in the 1950s and 1970s (Carter and Moghissi, 1977; Cambray and others, 1985). Deposited primarily through precipitation, ${ }^{137} \mathrm{Cs}$ strongly adsorbed to soil, especially to fine particles (less than $2 \mathrm{~mm}$ ) (He and Walling, 1996). By comparing the amount of ${ }^{137} \mathrm{Cs}$ bound to soil in a non-eroded or reference area to the amount in an eroded or depositional area, the rate in which soil has been redistributed (erosion/deposition) can be estimated (Walling and He, 1997; Ritchie and McHenry, 1990). In the Chesapeake Bay watershed, the ${ }^{137} \mathrm{Cs}$ technique has been used to estimate agricultural erosion and deposition in selected watersheds draining the Piedmont and Coastal Plain Physiographic Provinces (Gellis and others, 2009), including the Linganore Creek watershed (Clune and others, 2010).

For this study, rates of soil loss were determined for agricultural areas (pasture and cropland) and forested slopes in the Linganore Creek watershed. Some of the ${ }^{137} \mathrm{Cs}$ soil cores in agricultural areas were obtained by Clune and others (2010) during their study in the Linganore Creek watershed. Sampling sites for ${ }^{137} \mathrm{Cs}$ analysis were selected to obtain a spatial distribution of agricultural and forested areas. The agricultural sites selected for ${ }^{137} \mathrm{Cs}$ analysis included 10 pasture/hay and 8 cultivated crop settings (fig. 7). Thirteen forested sites and 3 reference sites ( 2 forested, 1 pasture) also were selected for ${ }^{137} \mathrm{Cs}$ analysis (fig. 7). The forest reference sites were chosen at the summit of slopes where erosion is minimal. The pasture reference site was taken from Clune and others (2010) and was located at the summit of an undisturbed (no erosion or deposition), fully vegetated, pasture/hay area that was enrolled in government conservation programs to minimize erosion (U.S. Department of Agriculture, 2009).

At each agricultural and forested site, 6-12 composite samples were collected along the slope of the agricultural field or forested areas (fig. 8). A composite sample was taken from three locations about $15 \mathrm{~m}$ apart along a contour (fig. 8). Soil was cored manually down to an estimated tillage depth (15-30 $\mathrm{cm})$ with a $3.5-\mathrm{cm}$-diameter stainless steel coring device. At agricultural sites, the tillage depth was determined on the basis of textural and color differences in the soil.

Soil samples were brought back to the USGS sediment laboratory in Baltimore, Md. and dried in an oven at $80^{\circ} \mathrm{C}$ for a minimum of 24 hours or until dry. Samples were ground using a mortar and pestle and mechanically sieved through a 2-mm screen (Ritchie and others, 2005). The soil fraction (less 


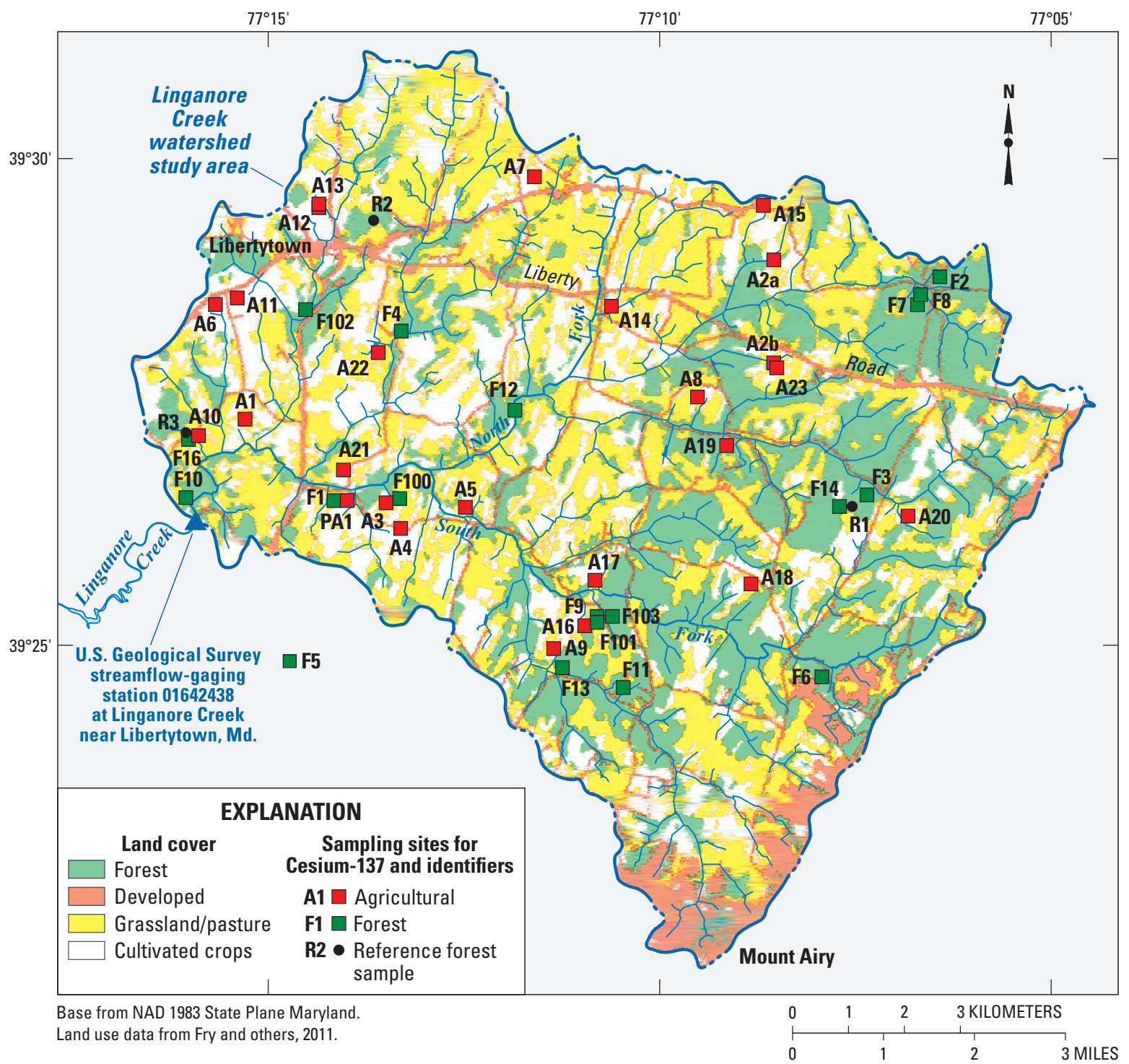

Figure 7. Location of sampling sites for Cesium-137 in the Linganore Creek watershed study area, Frederick and Carroll Counties, Maryland.

than $2 \mathrm{~mm}$ ) was weighed and sent to the USGS NRP laboratory in Reston, Va. for analysis of ${ }^{137} \mathrm{Cs}$ activity. ${ }^{137} \mathrm{Cs}$ results from Clune and others (2010) were analyzed at the U.S. Department of Agriculture-Agricultural Research Service (USDA-ARS) Hydrology and Remote Sensing Laboratory in Beltsville, Md. ${ }^{137} \mathrm{Cs}$ analysis at the USDA-ARS facility used gamma-ray procedures with a Canberra Genie-2000 Spectroscopy System that receives input from three Canberra high-purity coaxial Germanium $(\mathrm{Ge})$ crystals ( $\mathrm{HpC}$ greater than 30-percent efficiency) into 8192-channel analyzers. The system is calibrated and efficiency determined, using an analytic mixed radionuclide standard (10 nuclides) whose calibration can be traced to the U.S. National Institute of Standards and Technology. Samples are counted for a minimum of 24 hours. Measurement precision for ${ }^{137} \mathrm{Cs}$ is \pm 4 to 6 percent and inventory is expressed in becquerels per kilogram $(\mathrm{Bq} / \mathrm{kg})$ or becquerels per square meter $\left(\mathrm{Bq} / \mathrm{m}^{2}\right)$ (Ritchie, 2000, De Jong and others, 1982).

At the USGS NRP laboratories in Reston, Va., ${ }^{137} \mathrm{Cs}$ analyses were performed on samples in either a Marinelli or a flat geometry on a 20-percent relative efficiency coaxial highpurity Ge detector, depending on sample size. Both geometries were calibrated using the NBS 4350B river sediment standard. Self-adsorption corrections were made to the samples, if necessary, based on curves generated for both geometries over a range of weights of standard. Counting times ranged from 1 to, in some cases, 4 or 5 days. Errors calculated for each sample activity were based on propagation of counting statistics and the uncertainty of the value of the NBS 4350B standard activity (listed as 6.3 percent). 


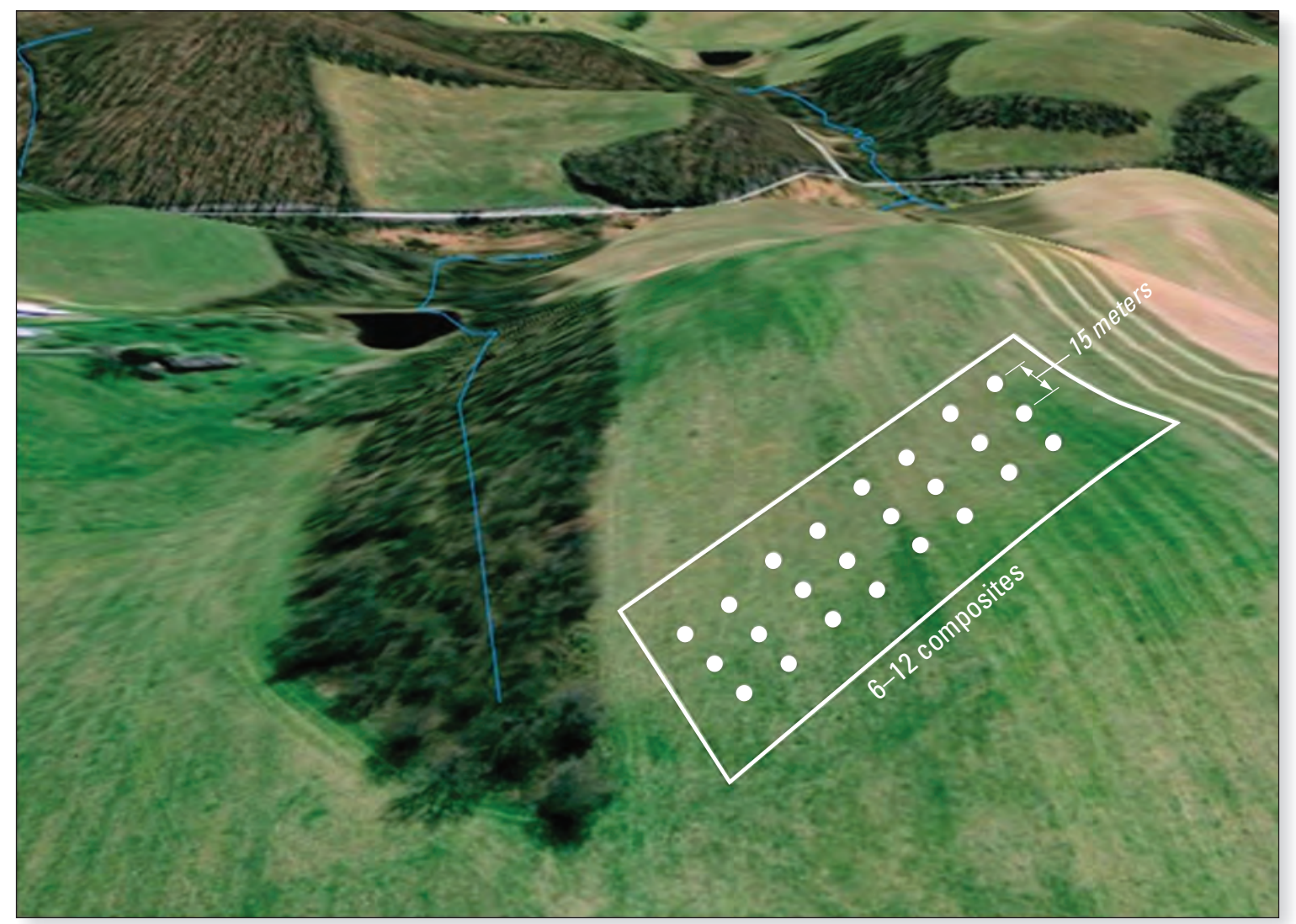

Figure 8. Illustration of the Cesium-137 sampling technique used in agricultural and forested areas in the Linganore Creek watershed. A composite sample was taken from three locations (represented by white dots in the photograph) that were approximately at the same elevation on the slope (contour) and 15 meters apart. At each slope, 6-12 composite samples were collected and analyzed separately for Cesium-137. [Photograph of Linganore Creek watershed from Clune and others, 2010.]

At agricultural sites, the ${ }^{137} \mathrm{Cs}$ inventory levels were used to estimate soil redistribution rates during approximately the past 50 years using the Mass Balance Model II described in Walling and $\mathrm{He}$ (1997). This theoretical mass balance model integrates ${ }^{137} \mathrm{Cs}$ inventory fluxes on the basis of the reference site inventory to predict overall erosion and deposition for a hillslope. Model II accounts for the total ${ }^{137} \mathrm{Cs}$ deposited at a site and any initial loss, decay, and erosion or deposition that occurs. ${ }^{137} \mathrm{Cs}$ inventories greater than the reference site ${ }^{137} \mathrm{Cs}$ activity are depositional and lesser inventory values are considered erosional. Model II provides results of soil loss or gain at a site in metric tons per hectare.

At forested sites, the ${ }^{137} \mathrm{Cs}$ inventory levels were used to estimate medium-term (approximately the past 50 years) soil redistribution rates using the Diffusion and Migration Model described in Walling and He (1997). The Diffusion and Migration Model was developed for uncultivated soils, such as forests, and takes into account the time-dependent behavior of both the ${ }^{137} \mathrm{Cs}$ fallout input and its subsequent redistribution in the soil profile. Results of soil loss or gain at a site using the Diffusion and Migration Model are expressed in metric tons per hectare.

\section{Sediment Storage in Ponds}

Ponds can be important storage sites of sediment (Renwick and others, 2005). Small ponds are common in the Linganore Creek watershed. Because of limited resources and the short timeframe of this study, determining the mass of sediment deposited in ponds over the study period was not feasible. To determine the mass of sediment that might be stored annually in the ponds during the study period, an inventory of the number of ponds in the Linganore Creek watershed and an estimate of sediment delivered to these ponds was made.

A GIS coverage showing the location of ponds for the Linganore Creek watershed was made using ortho-imagery data (6-inch, 2007 color imagery obtained from the Maryland Department of Natural Resources) (fig. 9). The ponds were identified on the imagery and digitized into a polygon shape file in a GIS. The ponds were classified by type, which included stormwater, construction site, farm, and other. The stream order of each pond was determined using the GIS and the length of streams and their orders draining into each pond were quantified. Ponds classified as zero order were either not 
located on a stream channel (such as on a slope) or were on drainages too small to be classified as 1st order by the GIS.

Another polygon shape file was created to delineate the drainage area of each pond. Contour lines were created from a 10-m USGS NED digital elevation model (DEM) (http:// datagateway.nrcs.usda.gov/, accessed April 5, 2014). Landcover percentages were determined for each pond drainage area using the 2006 National Land Cover Dataset (NLCD). The land uses included cropland, pasture, forest, urban, and other (http://datagateway.nrcs.usda.gov/). If any ponds were within the drainage of a downstream pond, it was noted which pond they drained to and only the intervening stream lengths and intervening land uses were used in this analysis.

The drainage areas and length of different stream orders draining to each pond were used to estimate the mass of sediment that could be delivered to each pond. Agriculture and forest erosion rates determined from the ${ }^{137} \mathrm{Cs}$ technique were applied to the area of agriculture and forest in the drainage area of each pond. Estimates of mass of sediment derived from channel bed and streambank contributions were based on the sediment budget measurements and were applied to the length of stream order draining to each pond. The amount of sediment transported to a pond is determined as:

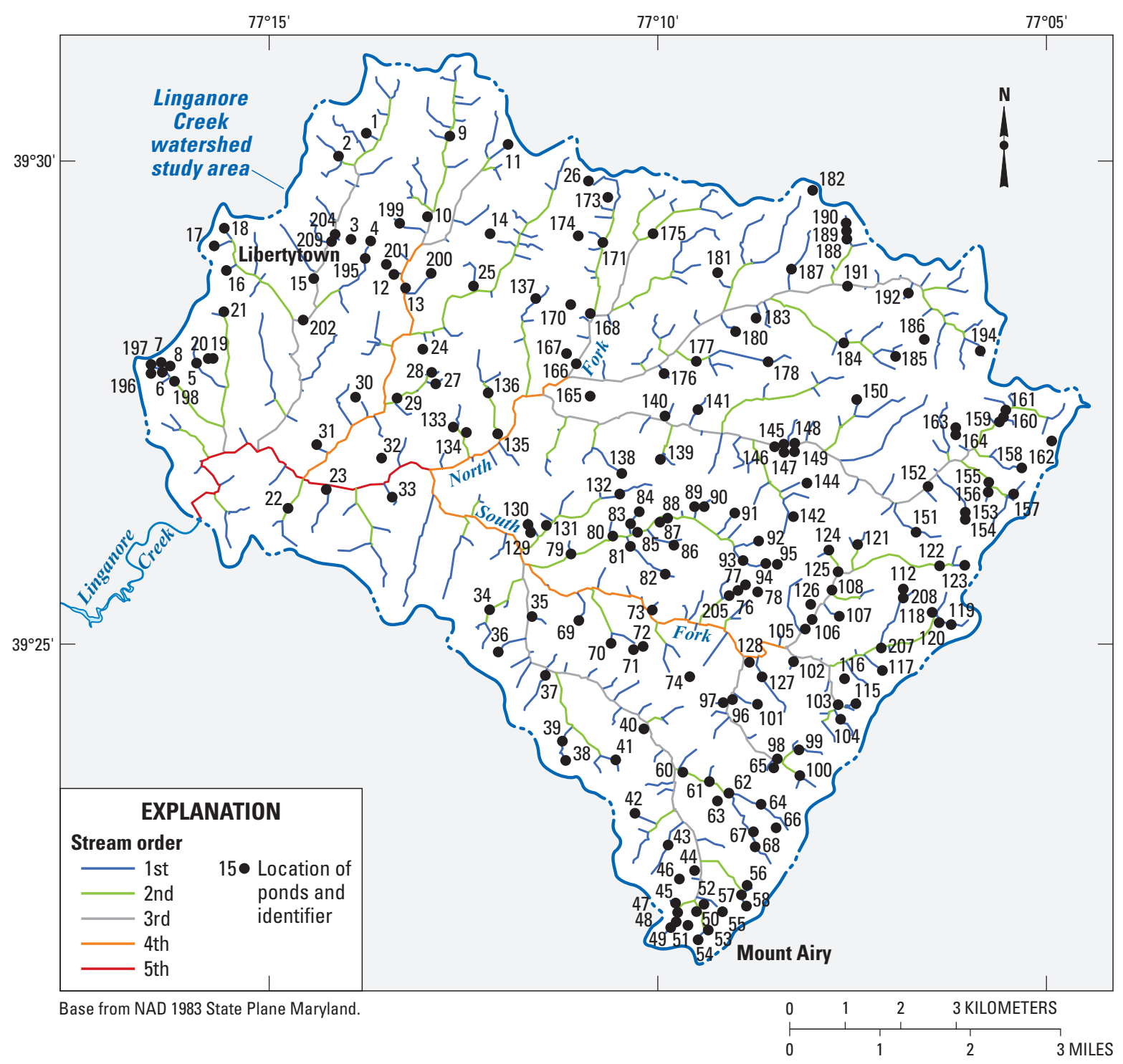

Figure 9. Location of ponds used in the sediment budget, Linganore Creek watershed study area, Frederick and Carroll Counties, Maryland. [Information on the type of pond, contributing area, and land use can be found in Appendix 11.] 


$$
P_{u s}=\sum_{p=1}^{n}\left(A G_{e r}+F R_{e r}\right)+\sum_{p=1}^{n} B K_{e r}+\sum_{p=1}^{n} B D_{e r}+\sum_{p=1}^{n} F P_{e r}
$$

where

$$
\begin{aligned}
& P_{u s} \quad=\text { the amount of sediment transported to a } \\
& \text { pond }(p) \text {; } \\
& A G_{e r} \quad=\text { sediment contributed from agricultural } \\
& \text { land draining above the pond or in the } \\
& \text { intervening area to the next upstream pond; } \\
& F R_{e r} \quad=\text { the amount of sediment contributed from } \\
& \text { forested lands draining above the pond or } \\
& \text { in the intervening area to the next upstream } \\
& \text { pond; } \\
& B K_{e r} \quad=\text { the total mass of sediment from bank } \\
& \text { deposition or erosion from streams } \\
& \text { draining above the pond or in the } \\
& \text { intervening area to the next upstream pond; } \\
& B D_{e r} \quad=\text { the total mass of sediment deposited or } \\
& \text { eroded in channels draining above the } \\
& \text { pond or in the intervening area to the next } \\
& \text { upstream pond; and } \\
& F P_{e r} \quad=\text { the total mass of sediment deposited in } \\
& \text { flood plains above the ponds or in the } \\
& \text { intervening area to the next upstream pond. }
\end{aligned}
$$

The mass of sediment deposited in a pond is a function of the pond's trap efficiency. The trap efficiency is the proportion of the incoming sediment that is deposited, or trapped, in a pond and is expressed as a percentage (Verstraeten and Poesen, 2000). Each pond has a unique trap efficiency. Information on the trap efficiency of ponds in the Linganore Creek watershed was not available and was estimated from pond trap efficiencies reported in the literature (Rausch and Schrieber, 1977; Heinemann, 1981; Cooper and Knight, 1990; Fiener and others, 2005). Trap efficiency is related to a number of variables including sediment input, size of sediment transported to the pond, runoff to the pond, the storage capacity of the pond, the amount of sediment deposited in the pond, and the shape of the pond (Verstraeten and Poesen, 2000). Heinemann (1981) showed that the trap efficiency of small ponds with drainage areas less than $36 \mathrm{~km}^{2}$ ranged from 2 to 100 percent.

The sediment trap efficiency for each pond in the Linganore Creek watershed was obtained by developing a relation of contributing area to the pond and sediment trap efficiency reported in the literature (fig. 10) (Rausch and Schrieber, 1977; Heinemann, 1981; Cooper and Knight, 1990; Fiener and others, 2005). The equation from the line of best-fit was applied to the drainage area of each pond in Linganore Creek to estimate a sediment-trap efficiency (fig. 10). The low $\mathrm{R}^{2}(0.29)$ of the regression model also indicates some uncertainty in the predictive power of the model. The estimated sediment-trap efficiency was then applied to the amount of sediment transported to each pond, using the equation:

$$
P_{d e p}=P_{u s} * T E
$$

where

$$
\begin{aligned}
P_{d e p} & =\text { the amount of sediment deposited in a pond; } \\
P_{u s} & =\text { the total mass of sediment transported to a } \\
& \text { pond; and }
\end{aligned}
$$

The difference in the mass of sediment transported to each pond minus the mass of sediment deposited in the pond is the mass of sediment transported past the pond, which is determined using the equation:

$$
P_{d s}=P_{u s}-P_{d e p}
$$

where

$$
\begin{gathered}
P_{d s} \quad \begin{array}{l}
=\text { the mass of sediment, in kilograms, } \\
\text { transported past the pond; }
\end{array} \\
P_{u s}=\text { the total mass of sediment, in kilograms, } \\
\text { transported to the pond; and } \\
P_{d e p} \quad \begin{array}{l}
\text { the amount of sediment deposited in the } \\
\text { pond, in kilograms. }
\end{array}
\end{gathered}
$$

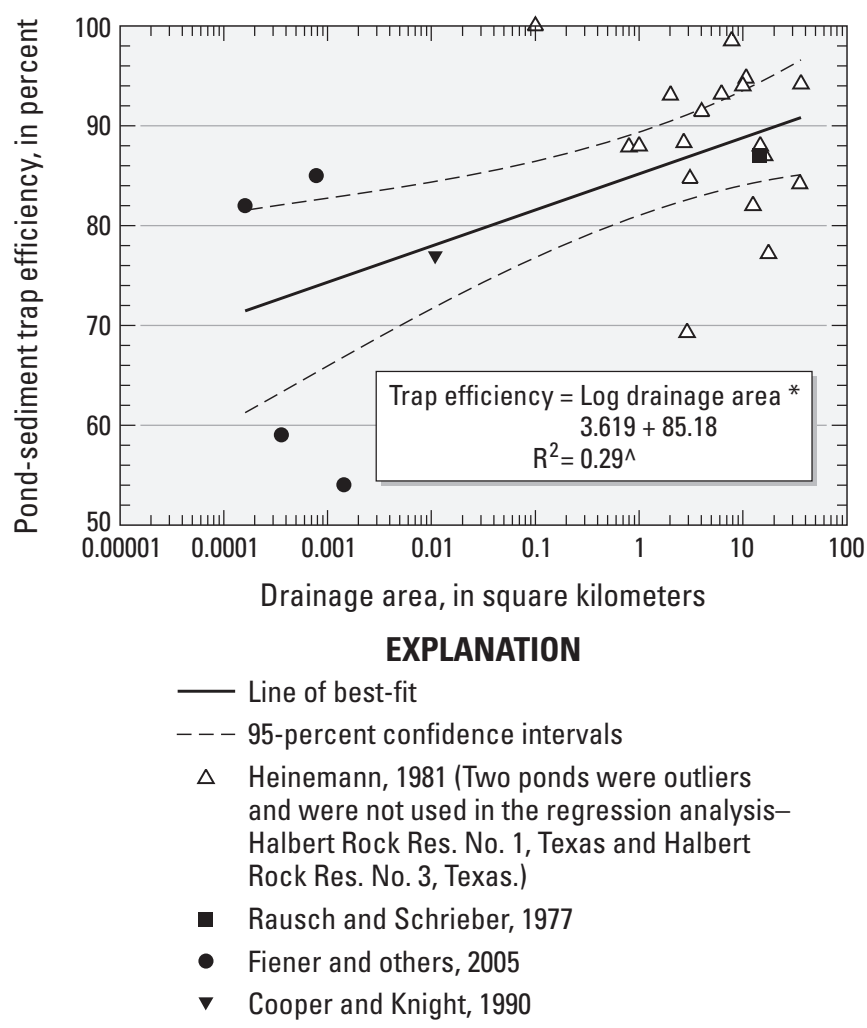

Figure 10. Regression analysis of drainage area and sediment trap efficiency used to estimate trap efficiency for ponds in the Linganore Creek watershed, Maryland. (Values were obtained from various sources in the literature. $A$ ' $\wedge$ ' indicates the slope of the regression line is significant $[p<0.05]$, and the residuals are normally distributed.) 
Many of the ponds in the Linganore Creek watershed are nested where either one or more ponds may be in the same small watershed. In this situation, ponds upstream of other ponds would be trapping some of the sediment generated in the small watershed. In situations where ponds were nested, the contributing area, land use, and stream lengths of different stream orders draining between the ponds were determined. The mass of sediment generated in the intervening area between ponds was determined and was assumed to be transported to the pond. Sediment that was transported past the upstream ponds would also contribute to the sediment in the downstream ponds. The mass of sediment transported to the downstream pond in a nested situation was determined using the equation:

$$
P_{u s}=\operatorname{Sed}_{c o n t}+P_{D s}
$$

where

$$
\begin{aligned}
& P_{u s} \quad=\text { the mass of sediment, in kilograms, } \\
& \text { delivered to a pond; } \\
& \text { Sed }_{\text {cont }}=\text { the mass of sediment, in kilograms, } \\
& P_{D s} \quad=\text { the mass of sediment, in kilograms, } \\
& \text { transported past an upstream pond or } \\
& \text { ponds. }
\end{aligned}
$$

The estimate of the mass of sediment deposited in ponds in this analysis is based on literature values of sedimenttrap efficiencies that were obtained from areas outside of the Linganore Creek watershed. The estimates used in this analysis could be improved by conducting additional studies that quantify the amount of sediment deposited in ponds in the Linganore Creek watershed.

\section{Computation of the Sediment Budget}

A sediment budget is an accounting of the sources (erosion), storage (deposition), and delivery (transport) of sediment in a watershed (equation 8). The field measurements of streambanks, channel beds, flood plains, and upland forested and agricultural areas were used to determine a fine-grained sediment budget for the Linganore Creek watershed between August 1, 2008 and December 31, 2010. The GIS coverage of ponds in the Linganore Creek watershed was used to estimate the mass of sediment that would be stored annually. The final fine-grained sediment budget for the Linganore Creek watershed was computed using the following equations:

$$
T_{s}=S_{k}+S_{b}+F_{p}+A_{g}+F_{r}+P_{d}
$$

where

$$
\begin{aligned}
T_{s}= & \text { total sediment export to the watershed } \\
& \text { outlet, in kilograms per year }(+=\text { erosion, } \\
& \text { - = deposition); }
\end{aligned}
$$
$S_{k} \quad=$ erosion or deposition from streambanks, in kilograms per year;
$S_{b} \quad=$ erosion or deposition from streambed, in kilograms per year;
$F_{p} \quad=$ deposition from flood plain, in kilograms per year;
$A_{g} \quad=$ erosion or deposition from agricultural areas, in kilograms per year;
$F_{r} \quad=$ erosion or deposition from forested areas, in kilograms per year; and
$P_{d} \quad=$ the total mass of sediment deposited in ponds, in kilograms per year.

and

$$
P_{d}=\sum_{p=1}^{n}\left(P_{\text {dep }}\right)
$$

where

$$
\begin{aligned}
& P_{d} \quad=\text { the total mass of sediment deposited in all } \\
& n \quad=\text { the number of ponds }(p) \text {; and } \\
& P_{\text {dep }} \quad=\text { the amount of sediment deposited in each } \\
& \text { pond, in kilograms per year (equation 19). }
\end{aligned}
$$

$$
S_{k}=\sum_{s=1}^{s=5}\left[\frac{K_{r(s)} * K_{\mu} *\left(L_{s} * 100\right) *\left(M_{k} / 100\right)}{1,000}\right]
$$

where

$$
\begin{aligned}
& S_{k} \quad= \text { erosion or deposition from streambanks; } \\
& K_{r(s)} \quad \text { net change in streambanks for stream } \\
& \text { order }(s), \text { in square centimeters per year } \\
& \text { (equation 13); } \\
& K_{\mu} \quad \begin{array}{l}
\text { streambank sediment density, in grams per } \\
\quad \text { cubic centimeter; }
\end{array} \\
& L_{s} \quad \begin{array}{l}
\text { length of streams for stream order }(s), \text { in } \\
\text { meters; and }
\end{array} \\
& M_{k} \quad \begin{array}{l}
\text { percent silt and clay in streambanks of } \\
\text { stream order }(s) .
\end{array}
\end{aligned}
$$

and

$$
S_{b}=\sum_{s=1}^{s=5}\left[\frac{B_{r(s)} * B_{\mu} *\left(L_{s} * 100\right) *\left(M_{b} / 100\right)}{1,000}\right]
$$

where

$$
\begin{aligned}
& S_{b} \quad=\text { erosion or deposition from streambed, in } \\
& \text { kilograms per year; } \\
& B_{r(s)} \quad=\text { net change in channel bed for stream } \\
& \text { order }(s) \text {, in square centimeters per year } \\
& \text { (equation 10); } \\
& B_{\mu}=\underset{\text { channel bed density, in grams per cubic }}{\text { centimeter; and }}
\end{aligned}
$$




$$
\begin{gathered}
M_{b} \quad=\text { percent of silt and clay in channel bed of } \\
\text { stream order }(s) .
\end{gathered}
$$

and

$$
F_{p}=\sum_{s=1}^{s=5}\left[\frac{F_{r(s)} * F_{\mu} *\left(L_{s} * 100\right) *\left(M_{f} / 100\right)}{1,000}\right]
$$

where

$$
\begin{array}{cc}
F_{p} \quad \begin{array}{l}
\text { deposition from flood plain, in kilograms } \\
\text { per year; }
\end{array} \\
F_{r(s)} \quad \begin{array}{l}
\text { net change in flood plain for stream } \\
\text { order }(s), \text { in square centimeters per year } \\
\quad \text { (equation 17); }
\end{array} \\
F_{\mu} \quad \begin{array}{l}
\text { flood-plain sediment density, in grams per } \\
\text { cubic centimeter; and }
\end{array} \\
M_{f} \quad \begin{array}{l}
\text { percent silt and clay in flood plain of stream } \\
\text { order }(s) .
\end{array}
\end{array}
$$

and

$$
\begin{gathered}
A_{g}=\left[A_{C s} *\left(S_{a} / 100\right) * A_{t}\right] * 1,000 \\
\left.F_{r}=\left[F_{C S} *\left(S_{o} / 100\right) * A_{f}\right)\right] * 1,000
\end{gathered}
$$

where

$$
\begin{array}{cc}
A_{g} \quad \begin{array}{c}
\text { total erosion or deposition from agricultural } \\
\text { areas, in megagrams per hectare per year; }
\end{array} \\
A_{C s} \quad \begin{array}{c}
\text { agricultural erosion estimated using }{ }^{137} \mathrm{Cs}, \text { in } \\
\text { megagrams per hectare per year; }
\end{array} \\
S_{a} \quad=\text { percent silt and clay in agricultural areas; } \\
A_{t} \quad=\text { total area in agriculture, in hectares; } \\
F_{r} \quad \text { total erosion or deposition from forested } \\
\quad \text { areas, in megagrams per hectare per year; } \\
F_{C s} \quad \text { forest erosion estimated using }{ }^{137} \mathrm{Cs}, \text { in } \\
\quad \text { megagrams per hectare per year; } \\
S_{o} \quad=\text { percent silt and clay in forest; and } \\
A_{f} \quad=\text { total area in forest, in hectares. }
\end{array}
$$

\section{Limitations and Uncertainty in the Sediment Budget}

Field measurements and laboratory analysis were required to develop the sediment budget. Uncertainty exists in the field measurements, laboratory analysis, and in the construction of the sediment budget. For this report, uncertainty is presented for the field measurements, laboratory analysis, and construction of the sediment budget.

\section{Measurement Uncertainty}

Every measurement has limitations in accuracy and contains a certain error. The approaches used in the sediment budget (channel surveys, bank pins, and flood-plain pads) measure erosion or deposition. Channel surveys were used to measure changes in the channel bed. Measurement error in surveying was assessed as the maximum difference in elevation in closing the survey (Harrelson and others, 1994). The maximum difference in elevation was obtained by initially surveying a monument or temporary benchmark (typically a pin in the ground that will not change elevation over the time it takes to survey the channel) and reshooting the same benchmark at the end of the survey. The difference in elevation (if any) is the error in the survey.

Bank pins were used to measure bank erosion and deposition. To determine the measurement uncertainty in reading bank pins and flood-plain clay pads, a stream reach in another watershed where a sediment budget study was ongoing (Difficult Run, Va.) was selected to run repeated measurements on bank pins and clay pads. Five observers measured bank pins on four streambanks; each bank contained three bank pins. Bank pins were established in Difficult Run, Va. in the same manner as Linganore Creek. Each bank pin was measured three times by an observer. To assess measurement uncertainty for the flood-plain clay pads, five observers each measured 10 pads. Each pad was measured three times by an observer. The measurement uncertainty in reading bank pins and clay pads was determined as follows:

$$
S D_{j(y)}=\sqrt{\frac{1}{2} \sum_{i=1}^{3}\left(x_{i}-\bar{x}\right)}
$$

where

$$
\begin{aligned}
S D_{j(y)} \quad= & \text { standard deviation of pin or pad } j \text { by } \\
& \text { observer } y \\
x_{i} & =\text { measurement } i \text { at pin or pad } j ; \text { and } \\
\bar{x} \quad= & \text { average of all pin or pad measurements. }
\end{aligned}
$$

Each observer's measurement uncertainty was determined by taking the average of the standard deviation of all pin or pad measurements, as follows:

$$
S S D_{\text {avg }(y)}=\frac{\sum_{i=1}^{M}\left(S D_{j(y)}\right)}{M}
$$

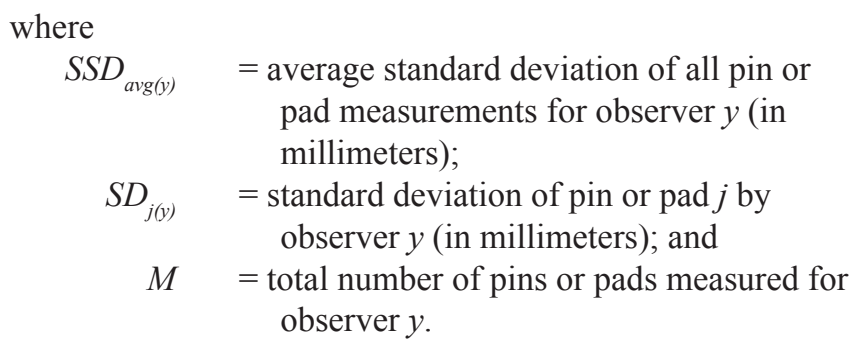


Final pin or pad measurement uncertainty $=$

$$
\frac{\sum_{y=1}^{Z}\left(S S D_{\operatorname{avg}(y)}\right)}{Z}
$$

where

$$
\begin{aligned}
S S D_{\operatorname{avg}(y)} & \begin{array}{c}
\text { average standard deviation of all pin or pad } \\
\text { measurements for observer } y ; \text { and }
\end{array} \\
Z \quad= & \text { total number of observers. }
\end{aligned}
$$

\section{Limitations and Uncertainty in Constructing the Sediment} Budget

Construction of the sediment budget relied on averaging and summing field measurements. A confidence interval is a range that encloses the true average of the measurement with a specified confidence interval. Confidence intervals (10th and 90th) were used to assess the uncertainty about the average of the field measurement. Because some of the field measurements were made on small datasets $(\mathrm{n}<25)$, bootstrapping, also known as permutations, was used for these small datasets to generate confidence intervals (Diaconis and Efron, 1983; Chernick, 2008).

Bootstrapping is a method of sampling from a dataset to make statistical inference about the variability in the data. The process involves randomly selecting samples but with replacement to produce replicate datasets. Each replicate consists of the same number of elements as the original dataset but may not include all the original elements; some elements may appear more than once, others may not appear at all. For this analysis 1,000 replicate datasets were generated using the bootstrapping command in the statistical package " $R$ " ( $R$ Development Core Team, 2011). The mean, 10th, and 90th confidence intervals were calculated for each replicate dataset. Bootstrapping does not require an assumption of normality.

In the computation of the sediment budget, measurement averages are multiplied and added (equation 22). The propagation of uncertainty (10th and 90th confidence intervals) has defined rules for multiplication, addition, and subtraction (Bevington and Robinson, 2003).

For multiplication where $\mathrm{Z}=\left(\mathrm{X}_{1}^{*} \mathrm{X}_{2} * \ldots * \mathrm{X}_{\mathrm{n}}\right)$ and $\mathrm{Z}$ is the product of multiplying measurements $X_{1}$ from 1 to $n$, propagation of uncertainty with confidence intervals is determined as:

$$
\Delta Z=\left|X_{1} * X_{2} * \cdots * X_{n}\right| * \sqrt{\left(\frac{\Delta X_{1}}{X_{1}}\right)^{2}+\left(\frac{\Delta X_{2}}{X_{2}}\right)^{2}+\cdots+\left(\frac{\Delta X_{n}}{X_{n}}\right)^{2}}
$$

where

$$
\begin{aligned}
\Delta Z \quad= & \text { the final uncertainty; and } \\
\Delta X_{1} \quad= & \text { confidence interval (10th or 90th) for } \\
& \text { measurements } X_{1} \text { from } 1 \text { to } n .
\end{aligned}
$$

For addition or subtraction, where $\mathrm{Z}=\mathrm{X} \pm \mathrm{Y}$, and $\mathrm{Z}$ is the sum of adding or subtracting measurements:

$$
\Delta Z=\sqrt{\left(\Delta X_{1}\right)^{2}+\left(\Delta X_{2}\right)^{2}}
$$

The 10th and 90th confidence intervals are shown for all measurements and for the final sediment budget totals in equation 22.

\section{Sources of Fine-Grained Sediment}

Sources of fine-grained suspended sediment in the Linganore Creek watershed were analyzed between August 1, 2008 and December 31, 2010. Rainfall has a strong control on erosion and sediment transport; therefore, it is important to determine whether the climatic conditions during the study period were similar or different from the longer historical record. Historical rainfall data were retrieved for Frederick, Md. approximately $12 \mathrm{~km}$ from the Linganore streamflowgaging station (U.S. Department of Commerce, 2011). Rainfall during the study period was compared to the long-term historical record (fig. 11). Variability in the difference of average monthly rainfall during the study period compared to the historical record is shown in figure 11, with the study period average monthly rainfall ranging from -37 to 21 percent of historical monthly values. Summing the average monthly rainfall for the study period $(1,020 \mathrm{~mm})$ and the historical record $(1,047 \mathrm{~mm})$, indicates that the average annual rainfall for the study period was within 3 percent of the historical annual rainfall. Therefore, although monthly averages of rainfall between the study period and the historical record were different, the annual differences were small and flow and sediment-transport conditions during the study period may reflect longer-term conditions.

\section{Sediment Transport}

Monthly and annual suspended-sediment loads transported during the study period are summarized in table 3 . Summing the average monthly suspended-sediment load produced an average annual suspended-sediment load of 6,374 megagrams per year $(\mathrm{Mg} / \mathrm{yr})$, and dividing by drainage area produced a sediment yield of 43.4 megagrams per square kilometer per year $\left(\mathrm{Mg} / \mathrm{km}^{2} / \mathrm{yr}\right)$ (table 3). This value is within the range of modern sediment yields reported for the Piedmont Physiographic Province of the Chesapeake Bay watershed (Gellis and others, 2005).

Suspended-sediment samples analyzed for the percentage of silt and clay ( $\mathrm{n}=368$ samples) indicated that the percentage of silt and clay ranged from 23 to 100 percent and averaged 87 percent for all samples (appendix 1). Taking the average percentage of silt and clay percent (87 percent) and multiplying by the average annual suspended-sediment load $(6,374 \mathrm{Mg} / \mathrm{yr})$ indicated that $5,454 \mathrm{Mg} / \mathrm{yr}$ of silt and clay is transported out of Linganore Creek annually. This amount is the output $O$ in equation 8 . 


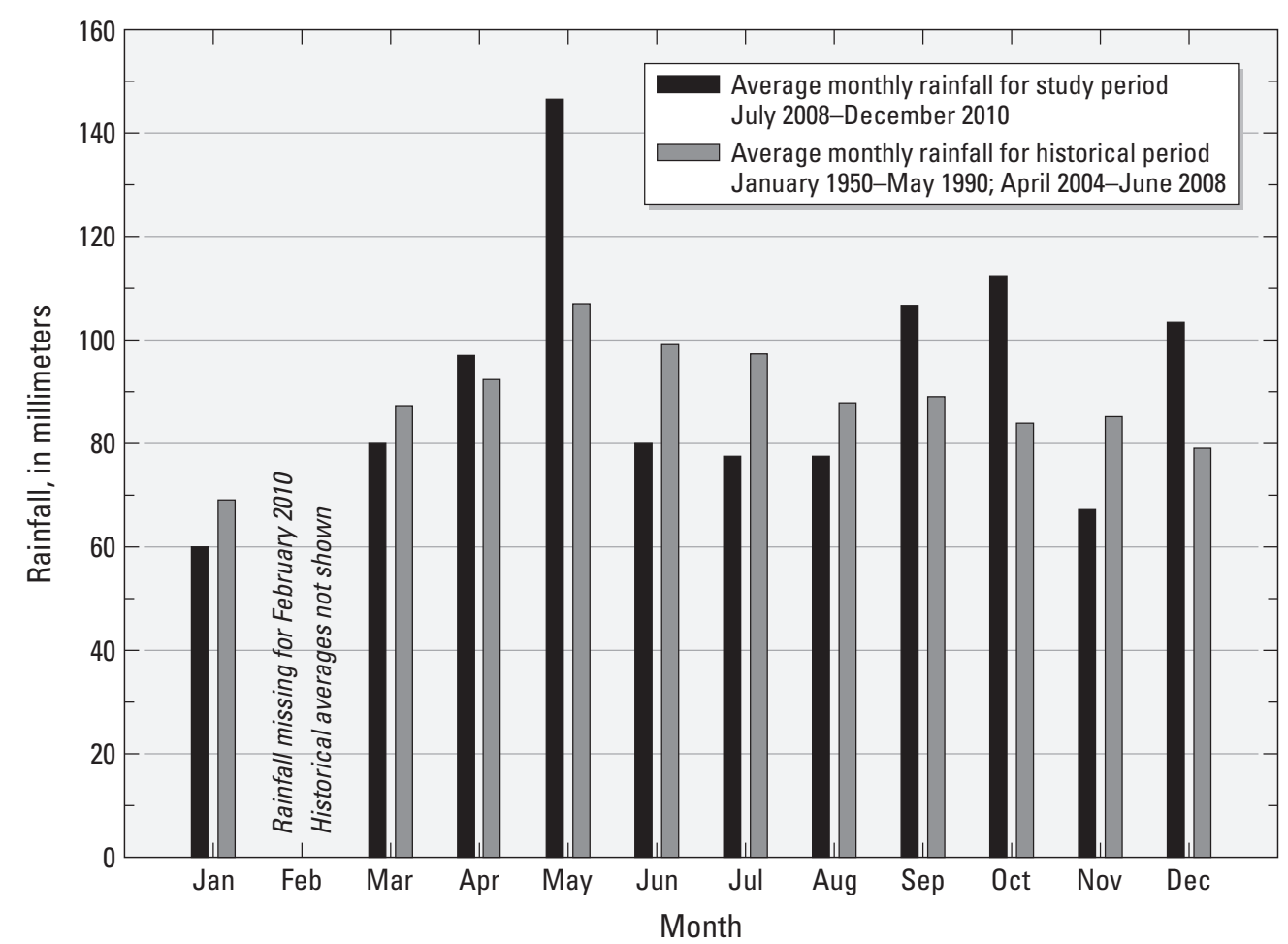

Figure 11. Average monthly rainfall for the study period (July 2008-December 2010) and period of record (January 1950-May 1990; April 2004-June 2008) for Frederick, Maryland. Rainfall data were obtained from the National Climatic Data Center (U.S. Department of Commerce, NCDC, 2011). [Rainfall station at Frederick, Maryland was listed as Frederick 3E from January 1950 to May 1990, and 2NNE from April 2004 to December 2010.]

Table 3. Summary of monthly and annual suspended-sediment loads for Linganore Creek near Libertytown, Maryland, August 2008 through December 2011.

[Mg, megagrams; $\mathrm{Mg} / \mathrm{yr}$, megagrams per year; $\mathrm{Mg} / \mathrm{km}^{2} / \mathrm{yr}$, megagrams per square kilometer per year]

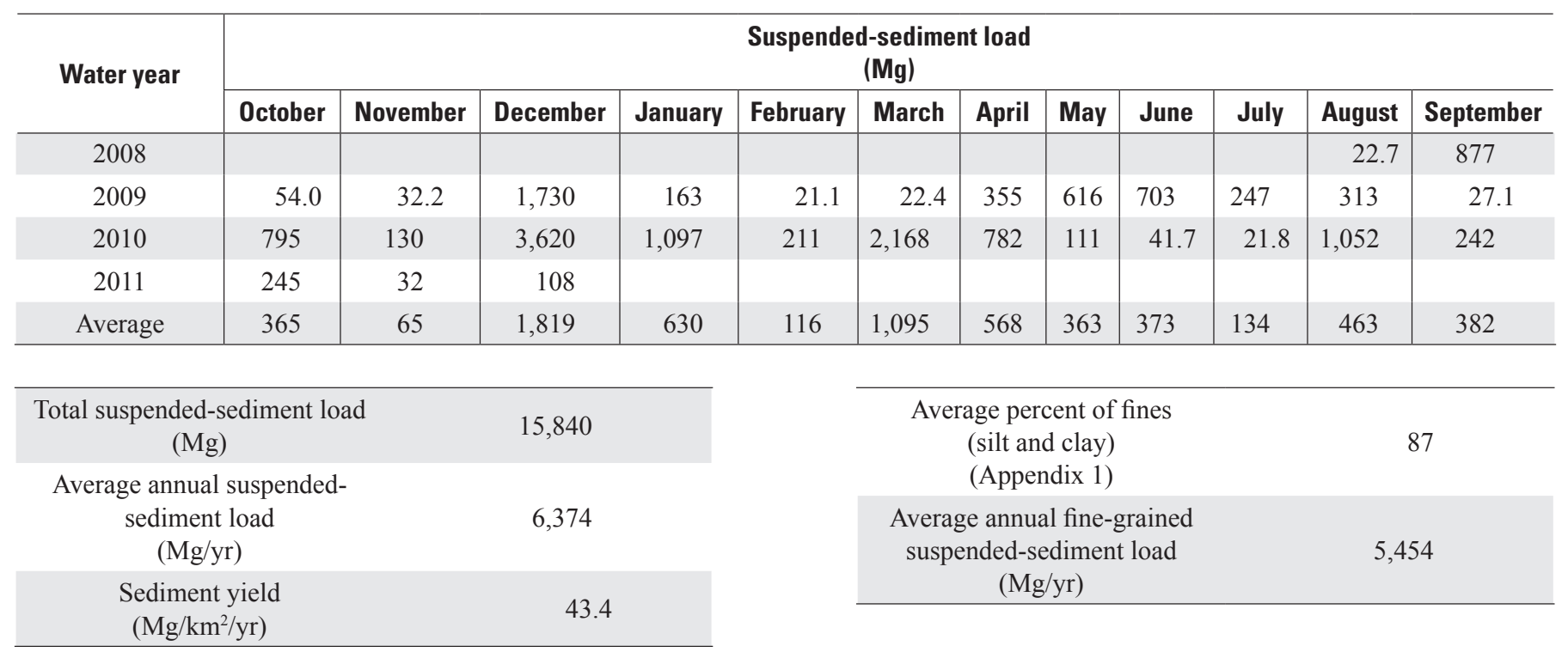




\section{Sediment Fingerprinting Results}

At the Linganore Creek near Libertytown, Md. streamflow-gaging station, 36 storm events were sampled for suspended-sediment sediment-source analysis from August 1, 2008 through October 1, 2010 (appendix 2). For each event, one or more sediment samples were collected over the storm hydrograph and analyzed for 23 tracers, totaling 194 suspended-sediment samples over the study period (appendix 2). The suspended-sediment load for the 36 events totaled $12,070 \mathrm{Mg}$, which is 76 percent of the total suspendedsediment load transported to Linganore Creek near the Libertytown, Md. streamflow-gaging station (15,840 Mg; table 3).

\section{Statistical Results}

Source samples for sediment-source analysis were collected from 40 streambanks, 24 agricultural areas, and 19 forested sites (fig. 6). Source samples were analyzed for 23 tracers (appendixes 3,4,5). Outliers were determined for normalized tracers in each source type and indicated that two streambank samples were outliers (appendix 3). These samples were removed. Plots of grain size $\left(\mathrm{D}_{50}\right)$ compared to tracer concentrations indicated a significant relation for one, three, and one tracers in agricultural, streambank, and forest samples, respectively, and a correction factor was applied to these tracers (table 4). Plots of TOC compared to tracer concentration indicated a significant relation for seven, five, and four tracers in agricultural, streambank, and forest samples, respectively, and a correction factor was applied to these tracers (table 5).

A bracketing test was performed on the tracers after they were corrected for grain size and organic content. Results of the bracketing test indicated that the fluvial samples were not bracketed by 10 tracers and these were removed (table 6). The final set of tracers used for stepwise DFA included 13 (aluminum, carbon, $\delta^{13} \mathrm{C}$, copper, iron, lithium, magnesium, manganese, nitrogen, nickel, phosphorous, lead, and vanadium) (table 6). Stepwise DFA was applied to the normalized set of tracers for all source types and showed that five tracers were significant (carbon, nitrogen, $\delta^{13} \mathrm{C}$, vanadium, and copper) (table 6). Results of the pairwise Mahalanobis Distance test indicated that this final set of six tracers was able to discriminate between all three source types (streambanks, agriculture, and forest) with a $\mathrm{p} \leq 0.05$. The DFA with five tracers successfully classified 95 percent of the source samples in their correct source category.

Tracer discriminatory weightings were applied to the six tracers (table 6) and the unmixing model was run for each fluvial sample (appendix 6a). The sediment-source results in appendix 6a are shown using two methods: (1) averaging the sources for each fluvial sample in the storm event, and (2) weighting the sources of each fluvial sample against the sediment load for the storm event (figs. 12a, b). The storm event source results were different for both methods. Averaging the results for all 36 storm events indicated that agriculture is the major source of sediment (61 percent), followed by streambanks (32 percent), and forest ( 7 percent). Weighting each sample's source results by the sediment load of that sample divided by the total sediment load for that event (stormweighted source percentage) also showed that agriculture was the major source ( 60 percent), followed by streambanks (34 percent), and forest (6 percent) (Appendix 6a). When the suspended-sediment load for each event is weighted by the total suspended-sediment loads of all events (total load weighted) $(12,070 \mathrm{Mg})$, streambanks are the major source of sediment ( 52 percent), followed by agriculture ( 45 percent), and forest (3 percent) (table 7). Differences in the results from the methods are related to the high sediment-loading events in which bank erosion was the major source of sediment (appendix 6a).

Table 4. Results of test to determine if regression of the median grain size of material less than 63 microns $\left(D_{50}\right)$ compared to tracer activity in source samples is significant. [Results are shown for normalized data.]

[Li, Lithium; B, Boron; Co, Cobalt; Sb, Antimony; Ni, Nickel]

\begin{tabular}{|c|c|c|c|c|c|c|c|c|}
\hline \multicolumn{9}{|c|}{ Summary of regression analysis used for size-correction factor } \\
\hline $\begin{array}{l}\text { Sediment- } \\
\text { source type }\end{array}$ & Tracer & $\begin{array}{l}\text { Transformation for } \\
\text { normality } \\
\text { for } D_{50}\end{array}$ & $\begin{array}{c}\text { Transformation } \\
\text { for normality of } \\
\text { tracer }\end{array}$ & $\begin{array}{c}\text { Slope of } \\
\text { line of } \\
\text { best fit }\end{array}$ & $\begin{array}{l}\text { p-value for } \\
\text { slope of } \\
\text { regression line }^{1}\end{array}$ & $\mathbf{R}^{2}$ & $\begin{array}{l}\text { p-value of } \\
\text { normality of } \\
\text { residuals }\end{array}$ & $\begin{array}{l}\text { Correction } \\
\text { factor }\end{array}$ \\
\hline Agriculture & $\mathrm{Li}$ & No transformation & No transformation & -4.14 & 0.04 & 0.24 & 0.93 & -11.9 \\
\hline Streambanks & $\mathrm{B}$ & No transformation & Inverse & -0.0004 & 0.03 & 0.21 & 0.32 & -0.0018 \\
\hline Streambanks & $\mathrm{Co}$ & Inverse & No transformation & -48.1 & 0.04 & 0.19 & 0.79 & -0.0039 \\
\hline Forest & $\mathrm{Ni}$ & Inverse & Squared & 916 & 0.05 & 0.50 & 0.74 & 125 \\
\hline
\end{tabular}

${ }^{1}$ Slope of the regression line for the normalized variables is shown for significance $\mathrm{p} \leq 0.05$. 
Table 5. Results of test to determine if regression of total organic carbon compared to tracer activity in source samples is significant. [Results are shown for normalized data.]

[Co, Cobalt; Fe, Iron; Li, Lithium; Mg, Magnesium; Pb, Lead; Ti, Titanium; V, Vanadium; P, Phosphorus; Sb, Antimony; B, Boron]

\begin{tabular}{|c|c|c|c|c|c|c|c|c|}
\hline \multicolumn{9}{|c|}{ Summary of regression analysis used for organic-correction factor } \\
\hline $\begin{array}{l}\text { Sediment- } \\
\text { source type }\end{array}$ & Tracer & $\begin{array}{l}\text { Transformation } \\
\text { for normality } \\
\text { of Carbon }{ }^{1}\end{array}$ & $\begin{array}{c}\text { Transformation } \\
\text { for normality of } \\
\text { tracer }\end{array}$ & $\begin{array}{l}\text { Slope of } \\
\text { line of } \\
\text { best fit }\end{array}$ & $\begin{array}{l}\text { p-value for } \\
\text { slope of } \\
\text { regression } \\
\text { line }^{2}\end{array}$ & $\mathbf{R}^{2}$ & $\begin{array}{c}\text { p-value of } \\
\text { normality of } \\
\text { residuals }\end{array}$ & $\begin{array}{c}\text { Correction } \\
\text { factor }\end{array}$ \\
\hline Agriculture & Co & No transformation & No transformation & -3.02 & 0.04 & 0.17 & 0.68 & -2.32 \\
\hline Agriculture & $\mathrm{Fe}$ & No transformation & No transformation & -6.48 & 0.03 & 0.19 & 0.37 & -4.98 \\
\hline Agriculture & $\mathrm{Mg}$ & Inverse & Inverse square root & -0.58 & 0.03 & 0.19 & 0.91 & 0.033 \\
\hline Agriculture & $\mathrm{Pb}$ & No transformation & No transformation & 4.79 & 0.02 & 0.22 & 0.48 & 3.68 \\
\hline Agriculture & $\mathrm{Ti}$ & No transformation & No transformation & -0.85 & 0.04 & 0.17 & 0.30 & -0.651 \\
\hline Agriculture & $\mathrm{V}$ & No transformation & No transformation & -16.8 & 0.03 & 0.20 & 0.46 & -12.9 \\
\hline Streambanks & $\mathrm{Ti}$ & No transformation & No transformation & -0.55 & 0.04 & 0.11 & 0.44 & 0.773 \\
\hline Streambanks & $\mathrm{V}$ & No transformation & Inverse & 0.0008 & 0.003 & 0.21 & 0.64 & -0.0011 \\
\hline Forest & B & No transformation & Inverse & -0.0012 & 0.04 & 0.22 & 0.57 & -0.0054 \\
\hline Forest & $\mathrm{Fe}$ & $\log$ & No transformation & -44.2 & 0.05 & 0.21 & 0.77 & -16.7 \\
\hline Forest & $\mathrm{Mg}$ & No transformation & $\log$ & -0.075 & 0.05 & 0.21 & 0.61 & -0.331 \\
\hline Forest & $\mathrm{Ti}$ & $\log$ & $\log$ & -0.23 & 0.01 & 0.31 & 0.44 & 0.314 \\
\hline
\end{tabular}

${ }^{1}$ Carbon in streambank samples was log transformed.

${ }^{2}$ Slope of the regression line for the normalized variables is shown for significance $\mathrm{p} \leq 0.05$.

\section{Relation of Sediment Sources to Peak Flow and Season}

Peak flow (or peak discharge) of an event is an indication of the strength of a storm event and is a function of the amount of precipitation and runoff generated to the stream (Rankl, 2004). In studies in Puerto Rico (Gellis, 2013) and Wyoming (Rankl, 2004), peak flow was significant in explaining stormgenerated suspended-sediment loads. In Linganore Creek, peak flow for each event (appendix 6a) showed a significant relation to the suspended-sediment load of the event (fig. 13a). Plots of storm-weighted contributions for the 36 storm events from streambanks compared to peak flow indicated that as peak flow increased, streambank contributions increased (fig. 13c). The increase in contribution from streambanks with higher peak flow indicates that streambanks may have been eroded during these events (discussed below). Contributions from storm-weighted source percentages from agriculture for the 36 storm events compared to peak flow showed that as peak flow increased, the source contributions from agriculture decreased (fig. 13b). The decrease in agricultural sediment with increasing peak flows may reflect the greater contributions from streambanks relative to agricultural sources during periods of high flow. Storm-weighted source percentages from forested areas did not show a relation to peak flow (fig. 13d).

Plots of storm suspended-sediment loads compared to storm-weighted source percentages showed similar results to peak flow (fig. 14). As storm suspended-sediment loads increased, contributions from streambanks increased and contributions from agriculture decreased (figs. 14a, b). Forest contributions did not show a strong correlation to storm suspended-sediment loads (fig. 14c).

The time of year also may be an important factor in determining whether specific sediment sources are important. Bare ground in agricultural areas is common before the growing season and after harvesting (Gellis and others, 2009). Wolman (1959) and Gatto (1995) have shown that in winter months, freeze-thaw action is an important process in the erosion of streambanks. Plots of storm-weighted sediment percentages are shown by month and averaged by season: winter (December to February), spring (March to May), summer (June to August), and fall (September to November) (fig. 15). The highest contributions from streambanks occurred 
Table 6. Statistical tests (bracket test, normality tests, and Stepwise Discriminant Function Analysis [DFA]) performed on tracers for all source types after a size and organic correction were applied. [Transformed tracers were used in the Stepwise DFA.]

[Al, Aluminum; As, Arsenic; B, Boron; C, Carbon; $\delta^{13} \mathrm{C}$, Stable isotopic total carbon; Ca, Calcium; Cd, Cadmium; Co, Cobalt; Cu, Copper; Fe, Iron; K, Potassium; Li, Lithium; Mg, Magnesium; Mn, Manganese; Mo, Molybdenum; N, Nitrogen; $\delta^{15} \mathrm{~N}$, Stable isotopic nitrogen; Ni, Nickel; P, Phosphorus; $\mathrm{Pb}$, Lead; Sb, Antimony; Ti, Titanium; V, Vanadium]

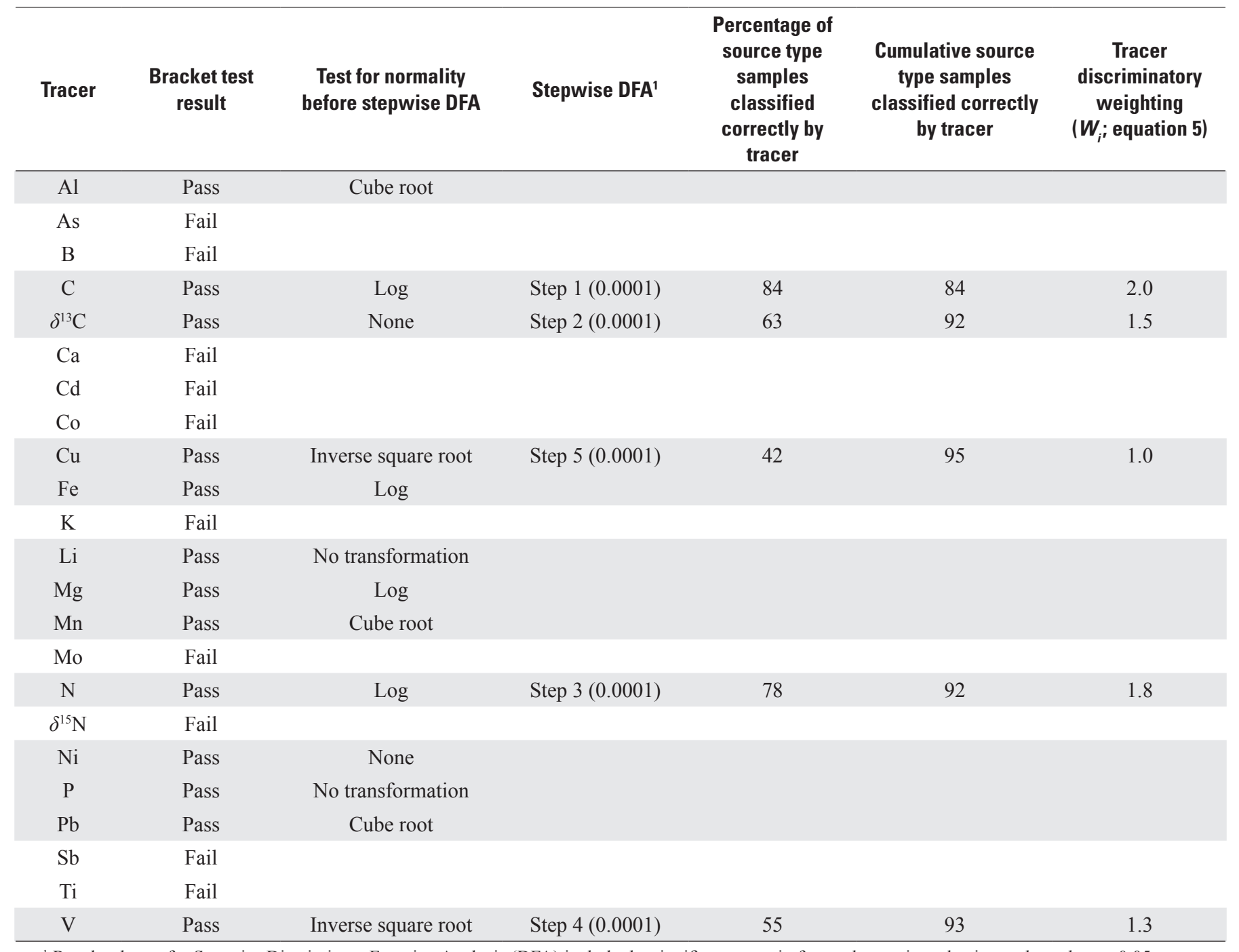

${ }^{1}$ Results shown for Stepwise Discriminant Function Analysis (DFA) include the significant steps in forward stepwise selection and $p$-values $\leq 0.05$.

in winter months (average 46 percent) (fig. 15a). A T-test performed on seasonal differences of sediment derived from streambanks indicated that winter months are significantly higher than non-winter months (fig. 15a).

Peak flow plotted against time of year showed the highest peak flows in the winter months, with three of the highest peak flows occurring in December (fig. 15d). The highest peak flow of the sampled events ( 55.5 cubic meters per second, or $\mathrm{m}^{3} / \mathrm{s}$ ) occurred on December 26, 2009 and contributed the highest storm-weighted percentage from streambanks for any event (average $=83$ percent) (table 7). This event had rainfall totals of $88 \mathrm{~mm}$ with a recurrence interval of 1 to 2 years (appendix 6a). A T-test performed on seasonal differences of peak flows indicated that winter months are significantly higher than nonwinter months (fig. 15d).

\section{Streambank Sources}

In the three primary mechanisms of bank erosion, which include freeze-thaw processes, fluvial erosion, and mass wasting, peak flow plays an important role in eroding streambanks. Greater masses of sediment produced by freeze thaw are removed as peak flow increases. Higher peak flows increase shear stress and erode streambanks and can be important when 

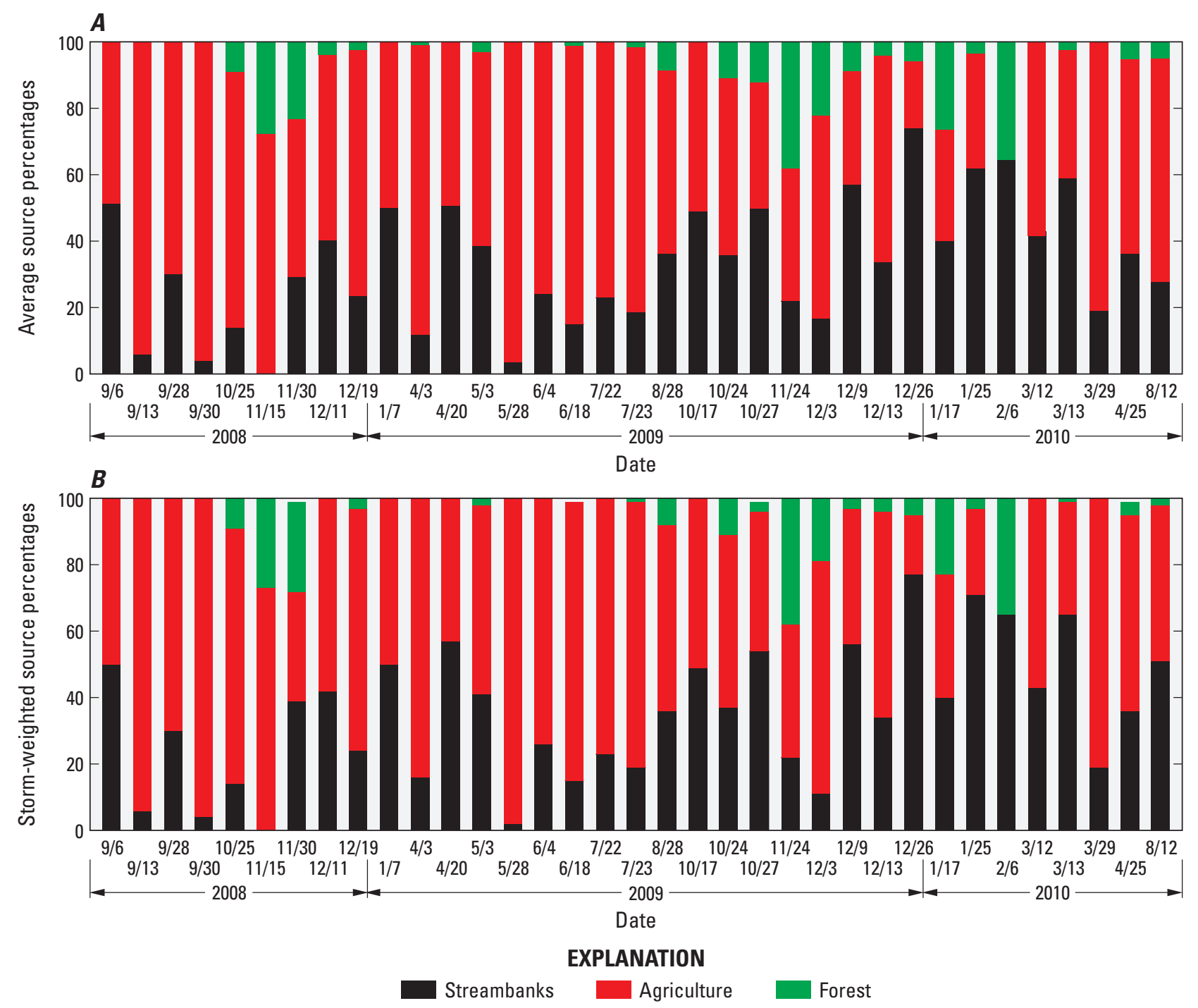

Figure 12. Results of sediment fingerprinting analysis for 36 storm events in Linganore Creek, September 6, 2008 through September 30, 2010, showing sediment sources as $(A)$ source results averaged for all samples collected during the event, and $(B)$ source results weighted by the sediment load of that sample divided by the total sediment load for that event.

bank failures occur during streamflow recession because of excess porewater pressure following a high stage.

In the Linganore Creek watershed, late fall through early spring commonly include days when temperatures fall above and below freezing. Plots of source areas with season indicate that the highest storm-weighted percentage of bank erosion occurs in the winter, December through February (average $=47$ percent ) (fig. 15a). Examination of climatic data for Frederick, Md. indicated that all storms sampled in the winter had at least 1 day of freeze thaw in the 5 days preceding the sampled event (appendix 6b) (U.S. Department of Commerce, NCDC, 2011). The higher contributions from bank sources in the winter months may reflect the importance of freeze-thaw activity in eroding sediment and peak flows in transporting this sediment.

\section{Upland Sources}

The lowest storm-weighted contributions of sediment from agriculture occurred in winter (45 percent), when bank erosion was highest (fig. 15b). A T-test performed on seasonal differences of sediment derived from agriculture indicated that winter months were significantly lower than non-winter months (fig. 15b). In the Linganore Creek watershed, the lower contributions from agriculture in the winter may reflect the higher contributions from bank erosion.

The highest storm-weighted contributions from agriculture (greater than 90 percent) occurred during three storms (event 2, September 13, 2008 [93 percent]; event 4, September 30 to October 1, 2008 [93 percent], and event 14, May 28, 2009 [98 percent]) (appendix 6a). Events 2, 4, and 14 were 
Table 7. Unmixing model results for 36 storm events in Linganore Creek. (Storm event results are shown for averages of individual samples collected on the storm hydrograph and weighted by the suspended-sediment loads of each sample divided by the total load of the storm event [Appendix 6a]).

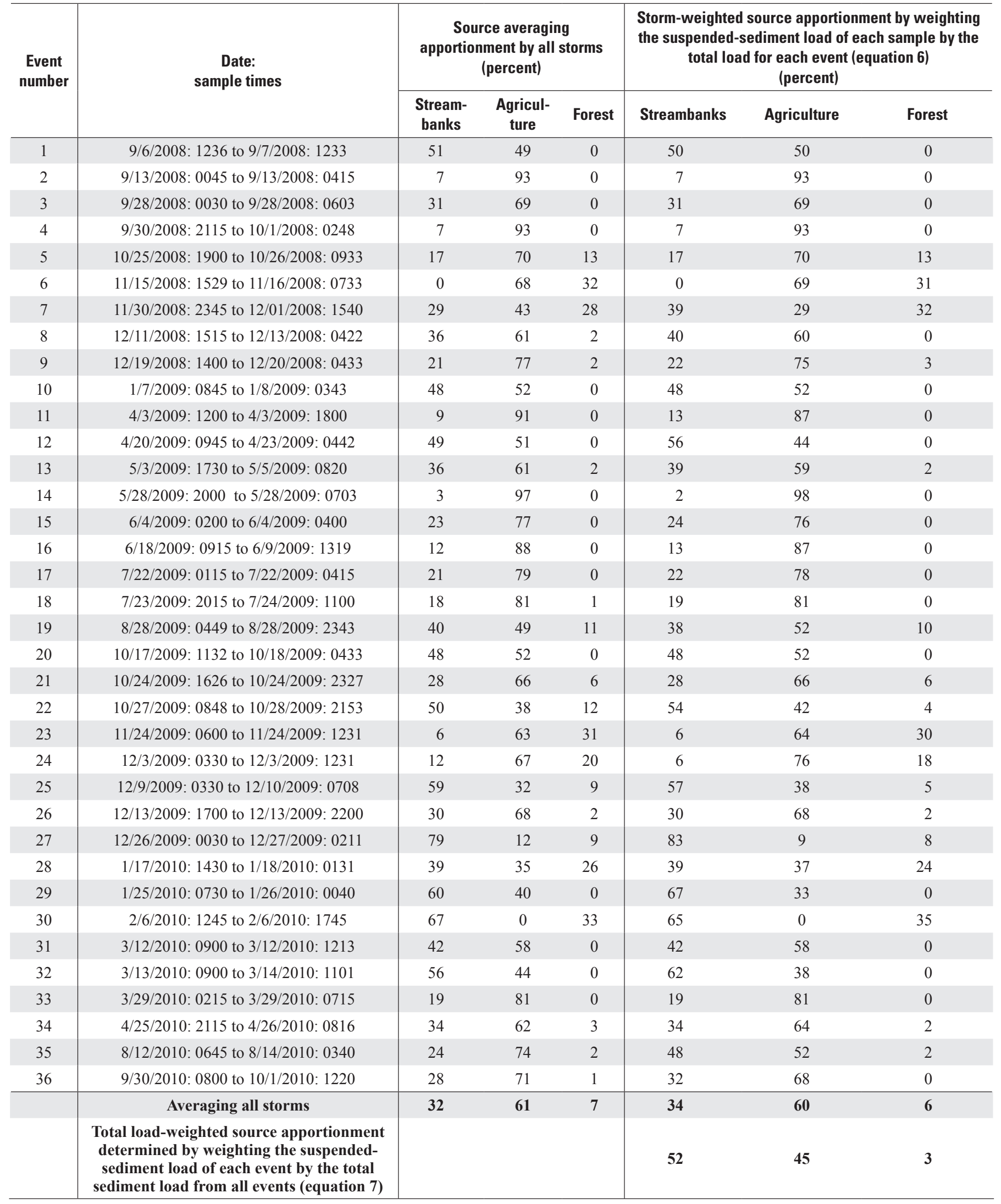



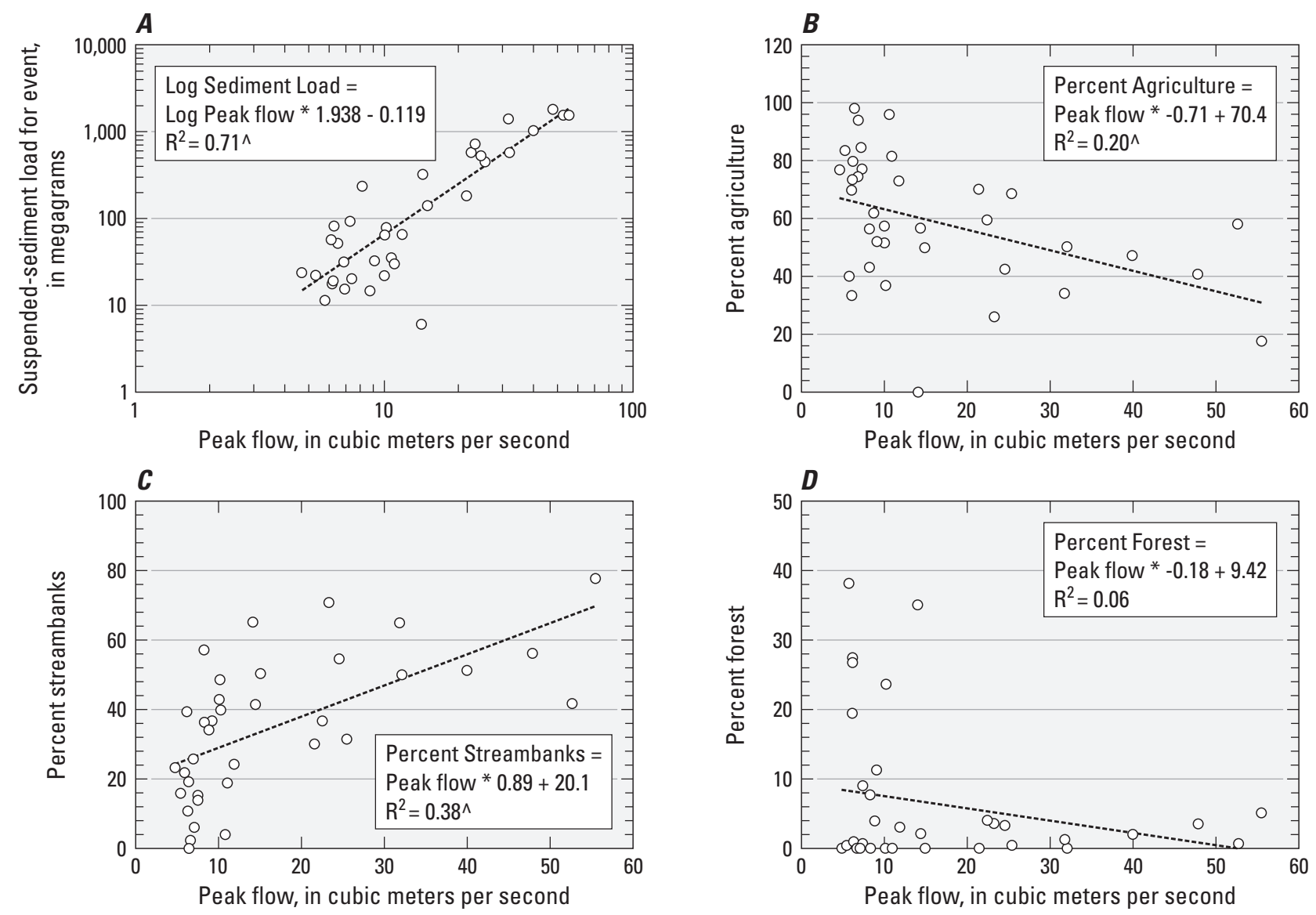

Figure 13. (A) Relation of peak flow to suspended-sediment load for sampled events. Relation of peak flow to storm-weighted source percentages for $(B)$ streambanks, $(C)$ agriculture, and $(D)$ forest. ( $A$ ' $\wedge$ ' indicates the slope of the regression line is significant $[p<0.05]$, and the residuals are normally distributed.)

moderate events where peak flows ranked 27, 17, and 29, respectively and rainfall totals ranked 20,22, and 28, respectively, where a rank of 1 has the highest peak flow and 36 has the lowest peak flow (appendix 6a). Spring, summer, and fall conditions on agricultural lands range from bare ground associated with tillage in the spring to full vegetative cover in the summer to bare ground following harvest in the fall. Higher contributions from agriculture in spring and fall could reflect conditions when fields have less vegetation. In agricultural watersheds in Belgium, summer contributions of sediment were low due to the increased vegetative cover (Steegen and others, 1998). Vegetative cover consisted of land in cultivation (wheat, sugar beets, and corn), pasture, and woodlands. High intensity thunderstorms occurring in the summer also have the ability to erode farm fields and transport agricultural sediment. In the Netherlands, soil loss in the summer was twice as high as winter soil loss and was caused by a high intensity rainfall event (Kwaad, 1991). Intense summer thunderstorms were observed in Linganore Creek during the study period, but rainfall intensity was not measured.

The highest sediment contribution from forests occurred during the fall (10 percent) and winter months ( 9 percent) (fig. 15c). For forest, significant differences occur between winter-fall and spring-summer (fig. 15c). The five highest storm-weighted sediment contributions from forest (greater than 20 percent) occurred during November, January, and February (events 23, 30, 7, 6, 28; appendix 6a). These events had moderate peak flows (ranked 34, 14, 33, 31, and 18, respectively), and moderate rainfall totals (ranked 25, missing data, 30, 10, and 24, respectively) (appendix 6a). November, January, and February are months when leaf-off conditions typically occur in forests and it is possible that bare ground was eroded during these storms. 

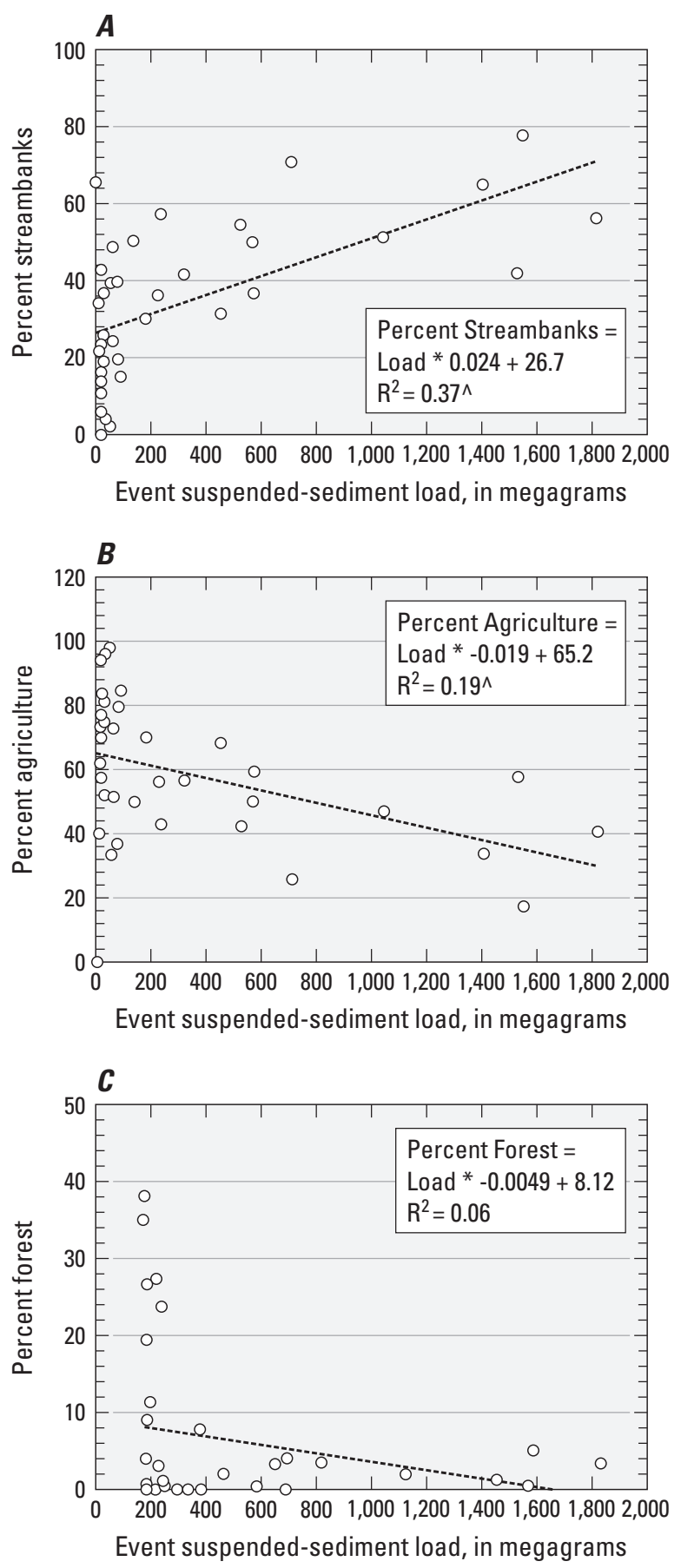

Figure 14. Relation of suspended-sediment load to storm-weighted source percentages in $(A)$ streambanks, $(B)$ agriculture, and $(C)$ forest. $\left(A{ }^{\prime} \wedge\right.$ ' indicates the slope of the regression line is significant $[p<0.05]$, and the residuals are normally distributed.)

\section{Limitations and Uncertainty in the Sediment Fingerprinting Results}

It should be pointed out that the sediment fingerprinting methods quantify the relative source percentage of sediment that is delivered to a point of interest in the watershed.

Although it is possible that some of the sampled sediment could have been eroded, transported, and delivered during the sampled event, it is also likely that a part of the sampled sediment may have been eroded in a previous storm event or events and had been in storage for a period of time until it was remobilized and sampled in the selected event (Gellis, 2013). Therefore, the sediment fingerprinting method does not determine what the temporal aspects of the sourced sediment may have been. In addition, since sediment that is in storage may become remobilized over subsequent events, the source of the stored sediment and its erosion, transport, and deposition may be related to previous storm events.

Because it is not known when the sediment was eroded, and where the sediment may have resided in storage (slopes, flood plains, or channels), caution should be observed when trying to interpret how sediment sources relate to the flow of a given sample. A large percentage of sediment eroded from upland surfaces, such as agricultural lands, is not delivered directly to the channel but goes into storage. The sediment delivery ratio (SDR) is the amount of sediment delivered to a point in the channel from a given source(s) divided by the gross erosion of the source(s). The SDR for cropland and pasture in the York River watershed, Va., a tributary of the Chesapeake Bay, was 0.31 (Herman and others, 2003) and the SDR for cropland in the Little Conestoga Creek watershed, Pa., also a tributary to the Chesapeake Bay, was 0.20 (Gellis and others, 2009). A SDR less than 1.0 indicates that some of the eroded sediment went into storage. Therefore, it is likely that some of the agricultural sediment that is apportioned during storm events in Linganore Creek is agricultural sediment that was in storage.

Streambank sediment is eroded directly into the channel during high flows and therefore has a high potential to be delivered to the sampling station during storm events. In Luxembourg, streambanks had a SDR of 1.0, indicating that all of the sediment eroded from streambanks was delivered out of the watershed (Duijsings, 1986). However, Skalak and Pizzutto (2010) describe the potential for a percentage of sediment derived from streambanks in the South River, Va., a tributary to the Chesapeake Bay, to remain in channel storage behind large woody debris for up to decades, which would indicate a SDR less than 1.0. Compared to upland-derived sediment (agriculture and forest), streambank-derived sediment has a greater potential to be eroded and delivered during an event, and it is likely that the sediment fingerprinting results for sediment derived from streambanks will show a significant relation to flow and seasonal conditions.

Sediment fingerprinting results will reflect sediment that was eroded and transported during the event as well as contributions from sediment that was in storage. The remobilized 

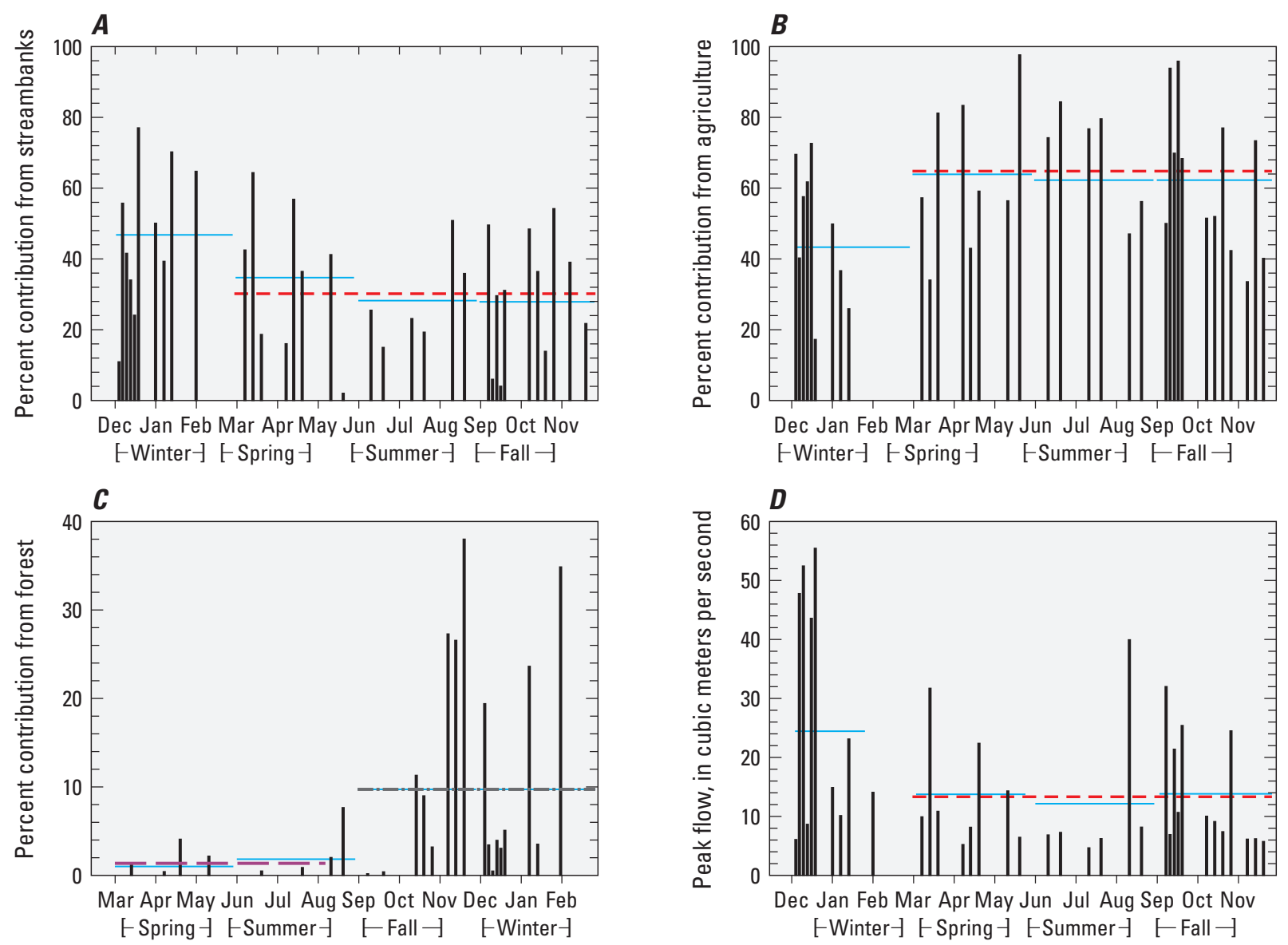

\section{EXPLANATION}

- Source percentage $\longrightarrow$ Seasonal average $\quad--$ Non-winter average

- - Spring-summer average - -.-- Fall-winter average

Figure 15. Storm-weighted source percentages shown by months and season for: $(A)$ streambanks, a T-test $(p=0.023$; data normally distributed) run on the data indicated a statistical difference between winter and non-winter months; $(B)$ agriculture, a T-test $(p=0.009$; data normally distributed) run on the data indicated a statistical difference between winter and non-winter months; and (C) forest, a Mann-Whitney Rank Sum test ( $\mathrm{p}=0.031$; data non-normally distributed) run on the data indicated a statistical difference between spring-summer and fall-winter months. (D) peak flow by month and season; a Mann-Whitney Rank Sum test ( $p=0.046$; data non-normally distributed) run on the data indicated a statistical difference between winter and non-winter months.

stored sediment will have tracers that reflect its source origin. By examining sediment sources over several storms or seasons, it may be possible to determine the amount of sediment from previous events that was in storage and remobilized.

\section{Monte Carlo Results}

Results of the Monte Carlo analysis indicate that all 194 suspended-sediment samples had average source percentages within 2 percent of the final sediment fingerprinting results (appendix 6a). For streambanks, the upper range of the Monte Carlo results averaged 2 percent higher than the fingerprinting results with a maximum difference of 10 percent. For streambanks, the lower range of the Monte Carlo results averaged 5 percent lower than the fingerprinting results with a maximum difference of 19 percent. For agriculture, the upper range of the Monte Carlo results averaged 6 percent higher than the fingerprinting results with a maximum difference of 19 percent. For agriculture, the lower range of the Monte Carlo results averaged 4 percent lower than the fingerprinting results with a maximum difference of 16 percent. For forest, the upper range of the Monte Carlo results averaged 2 percent higher than the fingerprinting results with a maximum difference of 8 percent. For forest, the lower range of the Monte Carlo results averaged 1 percent lower than the fingerprinting results with a maximum difference of 7 percent. 
Since the majority of samples have sediment-source differences between the average Monte Carlo results and the final set of fingerprinting results that are 2 percent or less, the unmixing-model results shown for the final set of source samples are considered robust. The maximum and minimum differences around the average Monte Carlo source apportionment have close to 50 percent of the samples within 5 percent of the final fingerprinting results and the majority of samples are less than 10 percent of the final fingerprinting results. The small differences in the Monte Carlo results between minimum and maximum values confirms that the final set of tracers gave reliable results.

\section{Sediment Budget Measurements}

A sediment budget was constructed for the Linganore Creek watershed between August 1, 2008 and October 15, 2010 and was based on the erosion and deposition occurring on the geomorphic elements shown in figure 5. Channel surveys were used to measure erosion and deposition on the channel bed. Pins were used to measure erosion and deposition on the channel banks and marker horizons were used to measure deposition on the flood plain. Erosion and deposition on agricultural and forested areas were based on the ${ }^{137} \mathrm{Cs}$ method.

\section{Channel Cross Sections}

Between August 11, 2008 and December 24, 2010, 22 reaches of Linganore Creek were surveyed to determine changes in channel-bed morphology (fig. 6; table 8; appendix 7a). At each reach, one to three cross sections were monumented with steel bars for resurveying. Changes in the channel bed are shown as changes in the bed area over time $\left(\mathrm{cm}^{2} / \mathrm{yr}\right)$ and summarized by stream order (fig. 16). Ten reaches showed erosion of the channel bed over time and 12 reaches showed deposition with the greatest rates of erosion or deposition occurring in higher order reaches (fig. 16). Averages of channel bed changes used to develop the sediment budget are shown in table 8.

\section{Streambank Erosion and Deposition}

Fifty reaches of Linganore Creek were instrumented with pins to measure streambank changes between August 11, 2008 and December 24, 2010 (fig. 6; table 9; appendix 7a). The number of pins installed in a streambank ranged from one to nine. For construction of the sediment budget, erosion and deposition of streambanks are shown as cross-sectional area changes over time $\left(\mathrm{cm}^{2} / \mathrm{yr}\right)$ summarized by stream order (fig. 17a; table 9) and by location (fig. 17c), and are shown as linear erosion rates (cm/yr) by location (fig. 17b; table 9).

The average of all reaches $(n=50)$ was erosion of -5.29 $\mathrm{cm} / \mathrm{yr}$ and ranged from deposition of $2.7 \mathrm{~cm} / \mathrm{yr}$ to erosion of $-52.7 \mathrm{~cm} / \mathrm{yr}$ (table 9). First order channels showed net deposition $\left(85.1 \mathrm{~cm}^{2} / \mathrm{yr} ; 0.17 \mathrm{~cm} / \mathrm{yr}\right)$, with 4 th order channels having on average the highest rates of streambank erosion $\left(-1,410 \mathrm{~cm}^{2} / \mathrm{yr} ;-12.8 \mathrm{~cm} / \mathrm{yr}\right)$ (table 9 ; figs. $\left.17 \mathrm{a}, \mathrm{b}, \mathrm{c}\right)$. The highest reach-averaged bank pin erosion of $-52.7 \mathrm{~cm} / \mathrm{yr}$ was recorded at a 4th order stream (E15 in figure 6) (fig. 17b; table 9). The rates of streambank erosion in Linganore Creek are similar to bank erosion values reported for other streams in the Chesapeake Bay watershed: 14.0 to $-16.3 \mathrm{~cm} / \mathrm{yr}$ (Schenk and others, 2012); -4 to -64 cm/yr (Merritts and others, 2011). For construction of the sediment budget, averages of streambank changes by stream order are shown in table 9 .

\section{Flood-Plain Deposition}

For the study period (August 1, 2008-December 31, 2010), deposition was measured on 78 pads for 20 reaches (appendix 7b). Deposition on the pads ranged from zero to 95 $\mathrm{mm}(0.126 \mathrm{~mm} / \mathrm{d})$ (appendix $7 \mathrm{~b})$. Flood-plain deposition rates were highest in 5th order streams (fig. 18).

Results of the stepwise regression model to estimate flood-plain deposition $(\mathrm{mm} / \mathrm{d})$ using explanatory variables of drainage area $\left(\mathrm{m}^{2}\right)$, elevation of the pads above the thalweg $(\mathrm{cm})$, and distance of the pad from the edge of the flood plain $(\mathrm{cm})$ are shown in appendix $7 \mathrm{~b}$ and summarized in table 10 . Testing for normality on the explanatory variables indicated that the distance of the pads from the edge of the stream and the contributing area to the pads were log-normally distributed and a $\log$ transformation was applied to these explanatory variables. Results of the stepwise regression model indicated that all the explanatory variables should remain in the model (table 10). The residuals from the regression showed a skewed-normal distribution with the Shapiro-Wilk test $(\mathrm{w}=0.81 ; \mathrm{p}=0.0001 ; \mathrm{Ho}=$ samples are random and come from a normal distribution) indicating that the power of the model to predict flood-plain deposition is weak. The low $\mathrm{R}^{2}$ (0.28) of the regression model also indicated some uncertainty in the predictive power of the model. Results from this study indicate that to obtain a more reliable estimate of flood-plain deposition, future studies should place more pads on a given channel cross section.

The final equation describing flood-plain deposition using the regression model is:

$$
\begin{aligned}
\mathrm{DEP}= & (-0.00015) \mathrm{Ep}+(-0.00737) \log \mathrm{Dp}+ \\
& (0.0138) \log \mathrm{Ar}-0.05
\end{aligned}
$$

where

$$
\begin{aligned}
\text { DEP = flood-plain deposition, in millimeters per } \\
\\
\text { day; } \\
\text { Ep = elevation of the pads above the thalweg, in } \\
\text { centimeters; } \\
\text { DP = } \\
\text { distance of the pad from the edge of the } \\
\text { flood plain, in centimeters; and } \\
\text { Ar = contributing area to reach, in square meters. }
\end{aligned}
$$




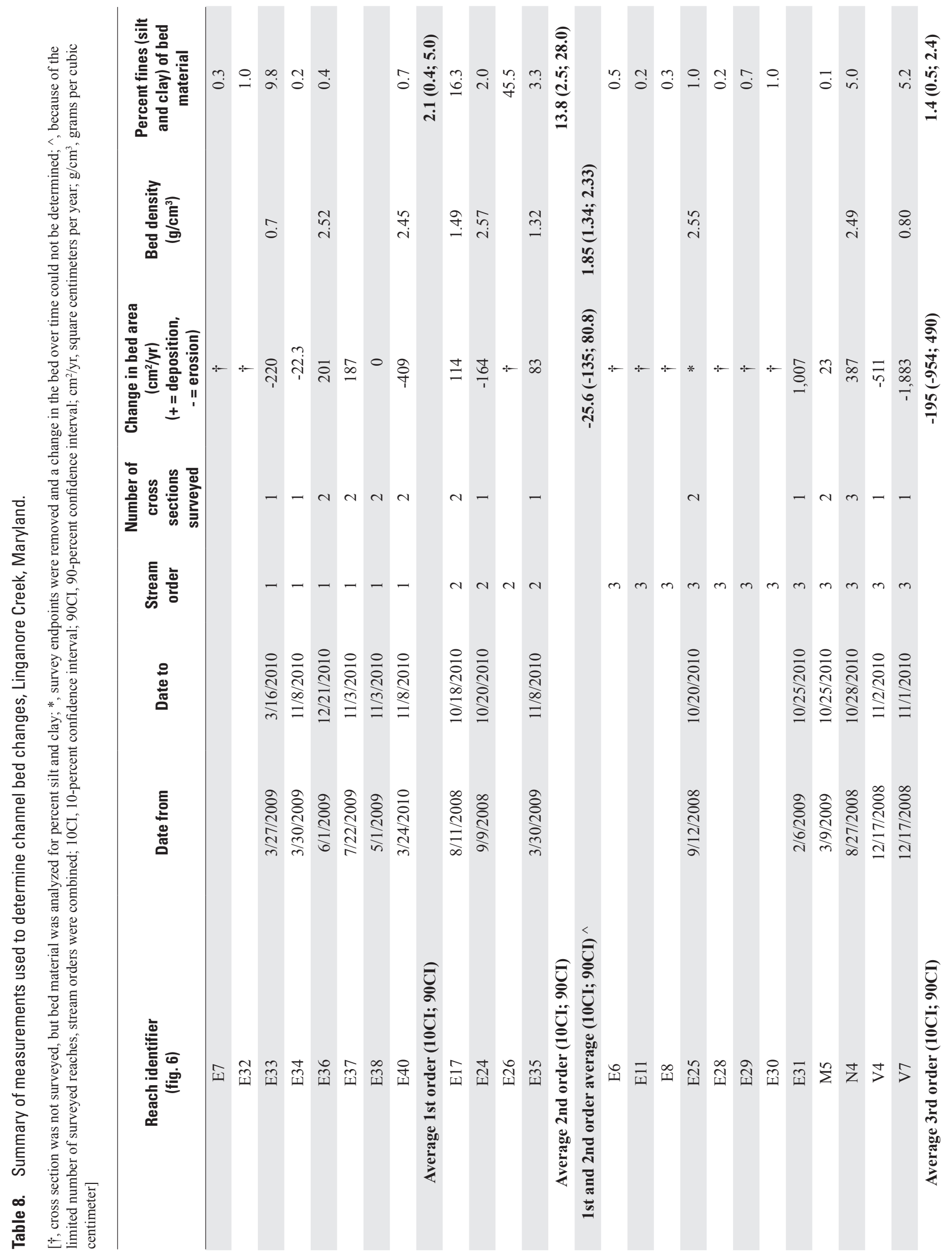




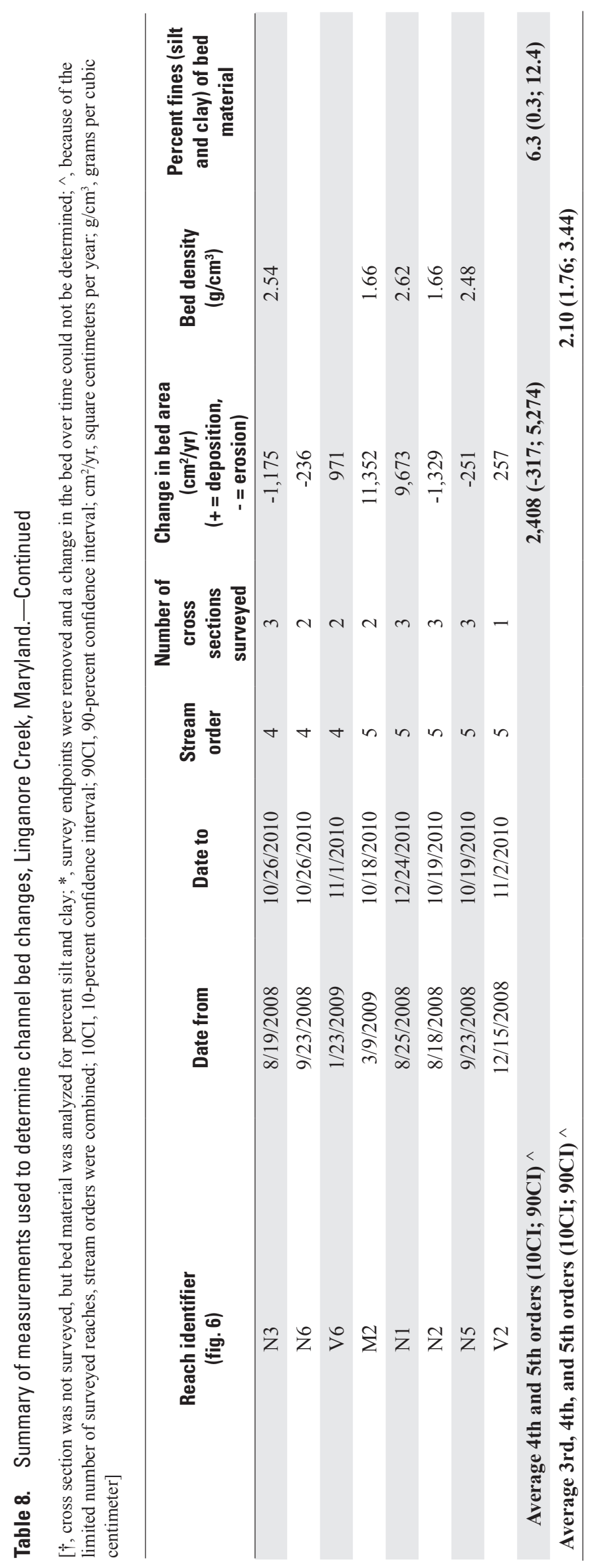



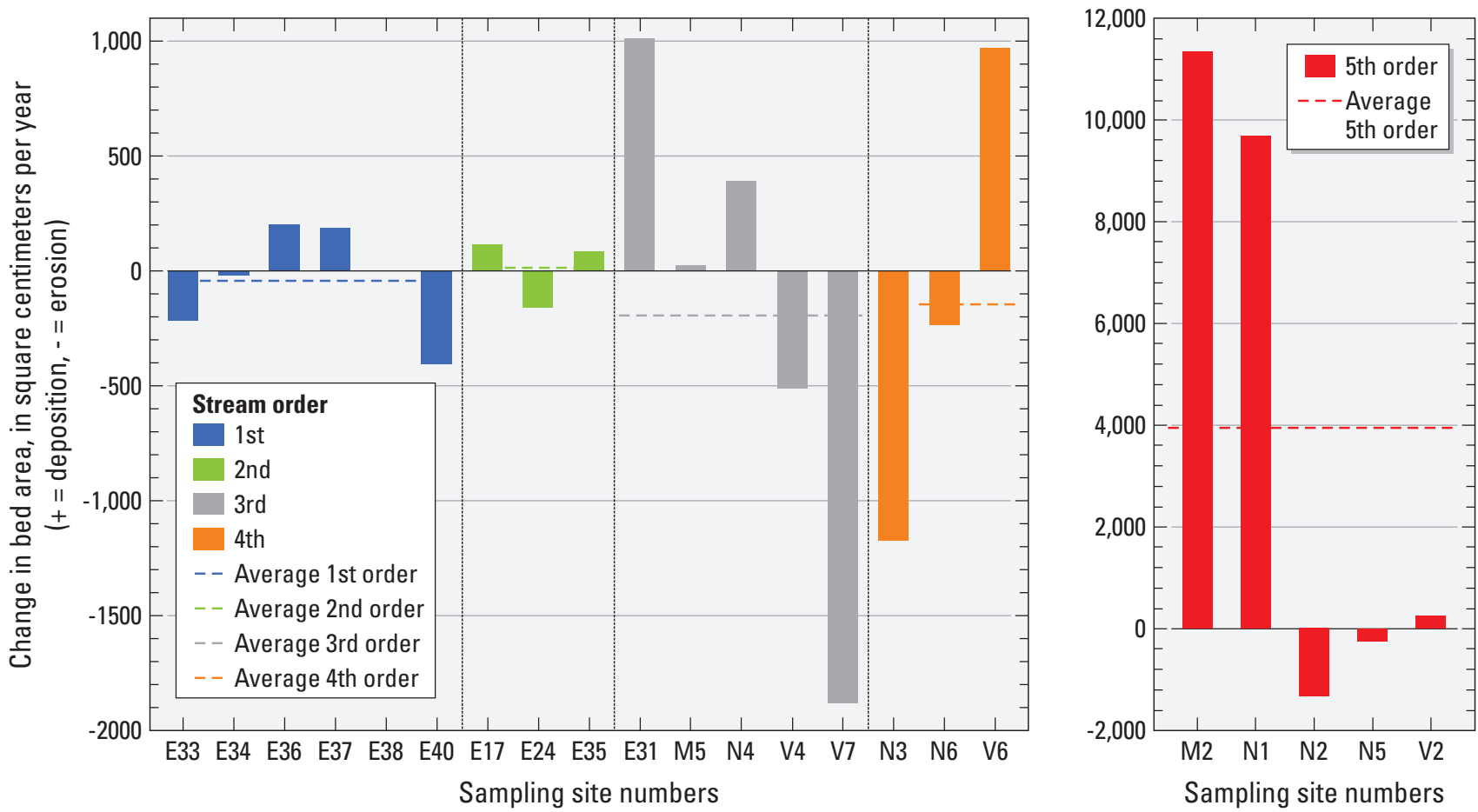

Figure 16. Bed changes in Linganore Creek determined through cross-section resurveys, August 1, 2008-December 24, 2010.

The regression model was applied to the surveyed cross sections to estimate deposition over the entire flood plain $\left(\mathrm{cm}^{2} / \mathrm{yr}\right)$ (appendix $\left.7 \mathrm{~b}\right)$. The highest rates of modeled floodplain deposition were on 4 th and 5 th order streams $(4.4 \mathrm{~mm} /$ yr; $1,572 \mathrm{~cm}^{2} / \mathrm{yr}$; appendix $\left.7 \mathrm{~b}\right)$. The modeled reach-averaged flood-plain deposition rates by stream order (table 11) showed increasing deposition rate with drainage area (fig. 19). This reflects both the increase in flood-plain width and increasing sedimentation rates with drainage area (fig. 19).

The 22 surveyed reaches used to estimate flood-plain sedimentation had modeled rates averaging 0.2 to $6.1 \mathrm{~mm} / \mathrm{yr}$ (appendix 7b). Flood-plain sedimentation rates ( $\mathrm{mm} / \mathrm{yr}$ ) measured on clay pads for Linganore Creek were similar to flood-plain deposition rates reported by Gellis and others (2009) for nine streams draining the Chesapeake Bay, which ranged from 1.0 to $7.5 \mathrm{~mm} / \mathrm{yr}$, and were within the range of flood-plain deposition rates reported for three streams draining the Piedmont Physiographic Province of the Chesapeake Bay, which ranged from 0.6 to $20.9 \mathrm{~mm} / \mathrm{yr}$ (Schenk and others, 2012).

\section{Upland Erosion and Deposition}

Inventories of ${ }^{137} \mathrm{Cs}$ were used to determine upland rates of erosion and deposition on 18 agricultural and 13 forested lands (fig. 7; appendixes 8 and 9). Two forested sites were selected as reference sites based on conversations with landowners indicating that they were undisturbed over the last 60 years (fig. 7; appendix 10). A third reference site was obtained from Clune and others (2010). The ${ }^{137} \mathrm{Cs}$ inventories were averaged for the three reference sites to obtain a value of $2,285 \mathrm{~Bq} / \mathrm{m}^{2}$ (appendix 10). This reference value is similar to the value of $2,432 \mathrm{~Bq} / \mathrm{m}^{2}$ used by Gellis and others (2009) in their study of erosion and deposition in agricultural fields in the Little Conestoga watershed, $\mathrm{Pa}$., which is also located in the Piedmont Physiographic Province.

The Mass Balance 2 model predicted erosion at all agricultural sites ranging from 4.5 to 33.5 megagrams per hectare per year $(\mathrm{Mg} / \mathrm{ha} / \mathrm{yr})$ and averaging $19.0 \mathrm{Mg} / \mathrm{ha} / \mathrm{yr}$ (fig. 20; table 12). In the Little Conestoga watershed, Pa., agricultural erosion rates averaged $19.4 \mathrm{Mg} / \mathrm{ha} / \mathrm{yr}$ (Gellis and others, 2005), a value similar to the one for the current study (19.0 Mg/ha/yr). In Linganore Creek, Clune and others (2010) estimated agricultural erosion to be $15.3 \mathrm{Mg} / \mathrm{ha} / \mathrm{yr}$. Differences between the Clune and others (2010) results and those in this study likely reflect the additional nine sites used in this study and the addition of two more reference sites.

The Diffusion and Migration Model predicted erosion on 11 forested sites and deposition on 2 forested sites, ranging from deposition of $1.3 \mathrm{Mg} / \mathrm{ha} / \mathrm{yr}$ to erosion of $7.1 \mathrm{Mg} / \mathrm{ha} / \mathrm{yr}$, and averaging erosion of $1.4 \mathrm{Mg} / \mathrm{ha} / \mathrm{yr}$ (fig. 20; table 12). No other studies in the Chesapeake Bay watershed have quantified erosion and deposition on forested slopes using the ${ }^{137} \mathrm{Cs}$ method. 


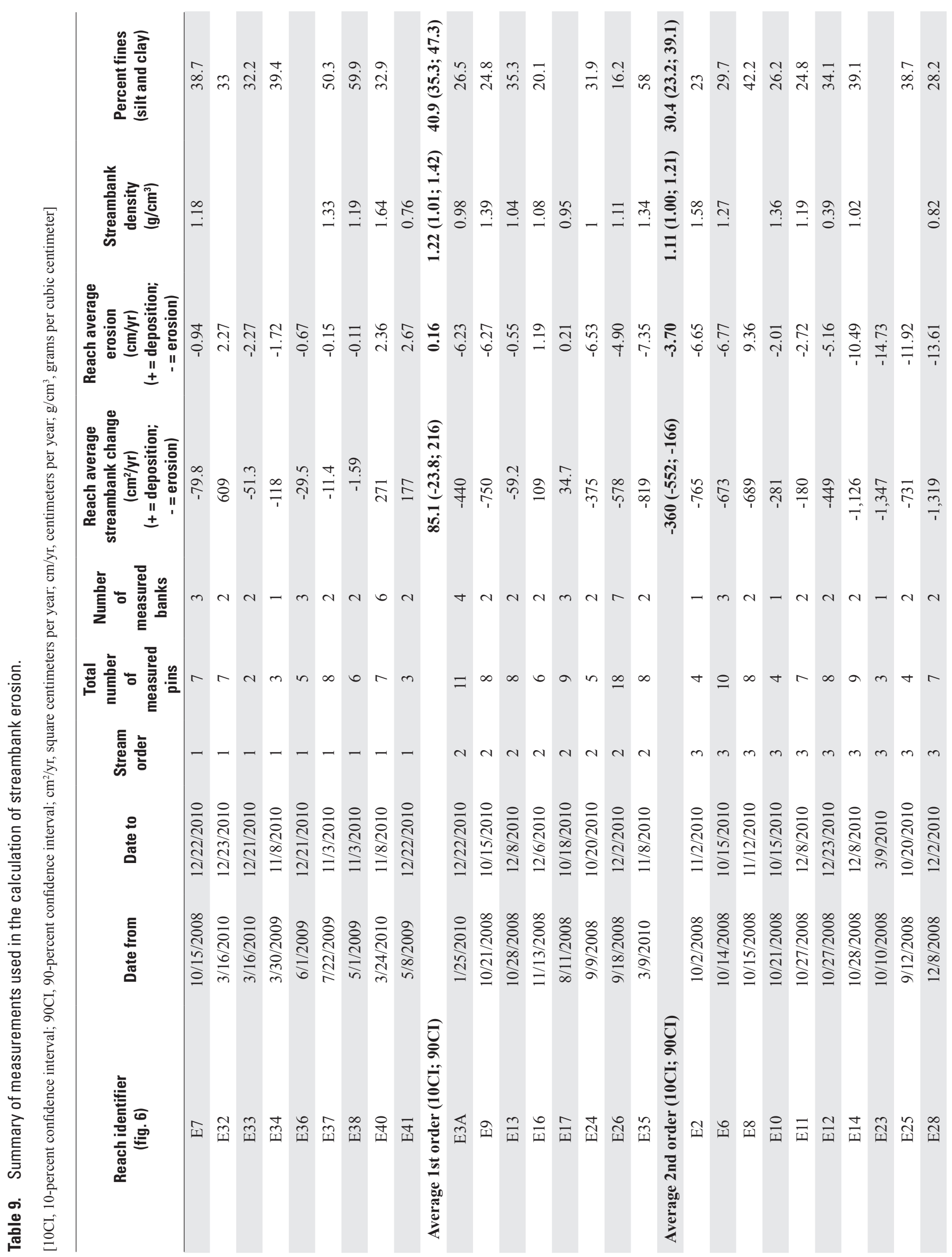




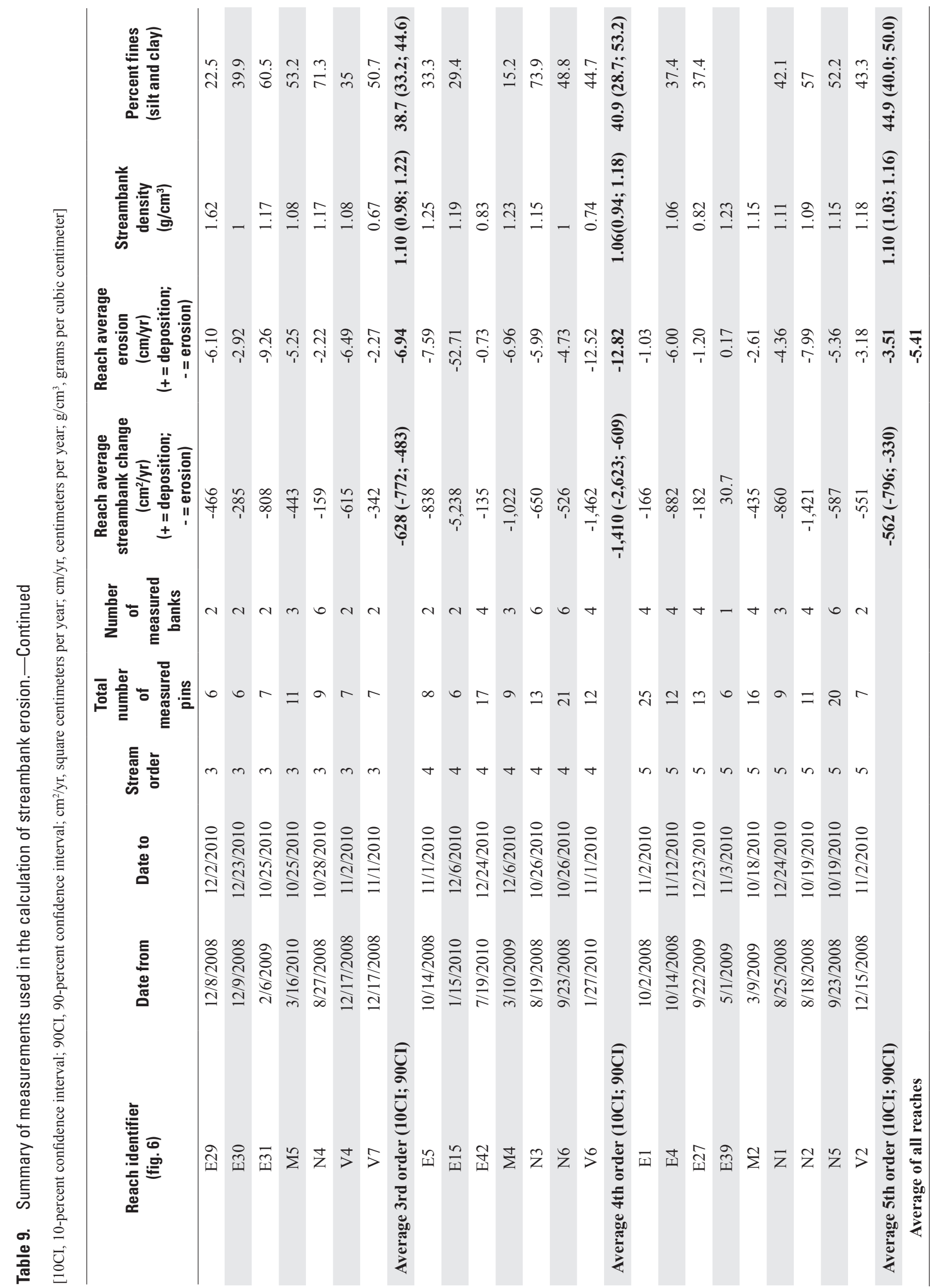



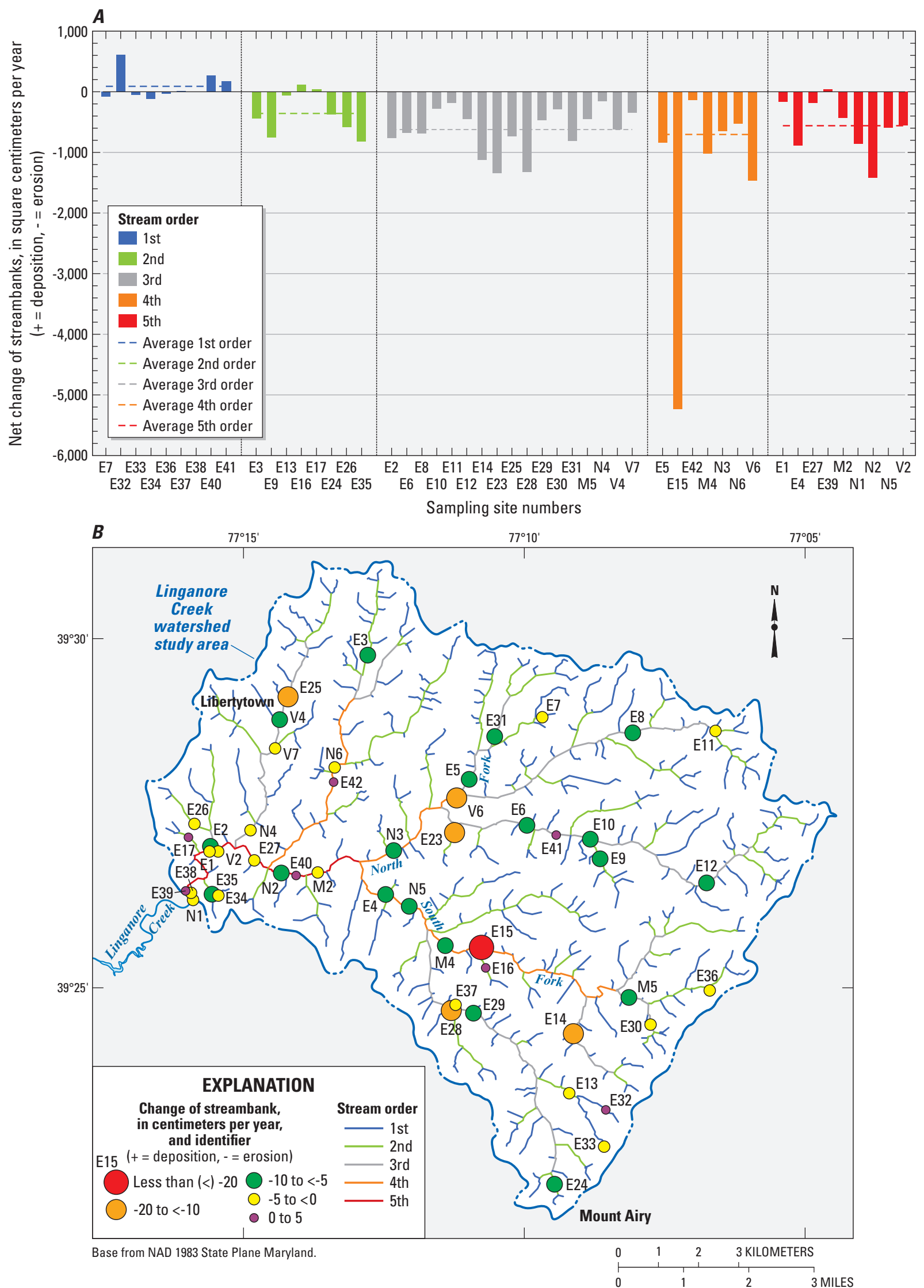

Figure 17. (A) Streambank changes determined through bank pin measurements, and reach-averaged streambank changes, $(B)$ centimeters per year, and $(C)$ square centimeters per year in Linganore Creek watershed study area, Frederick County, Maryland, August 11, 2008 through December 24, 2010. 


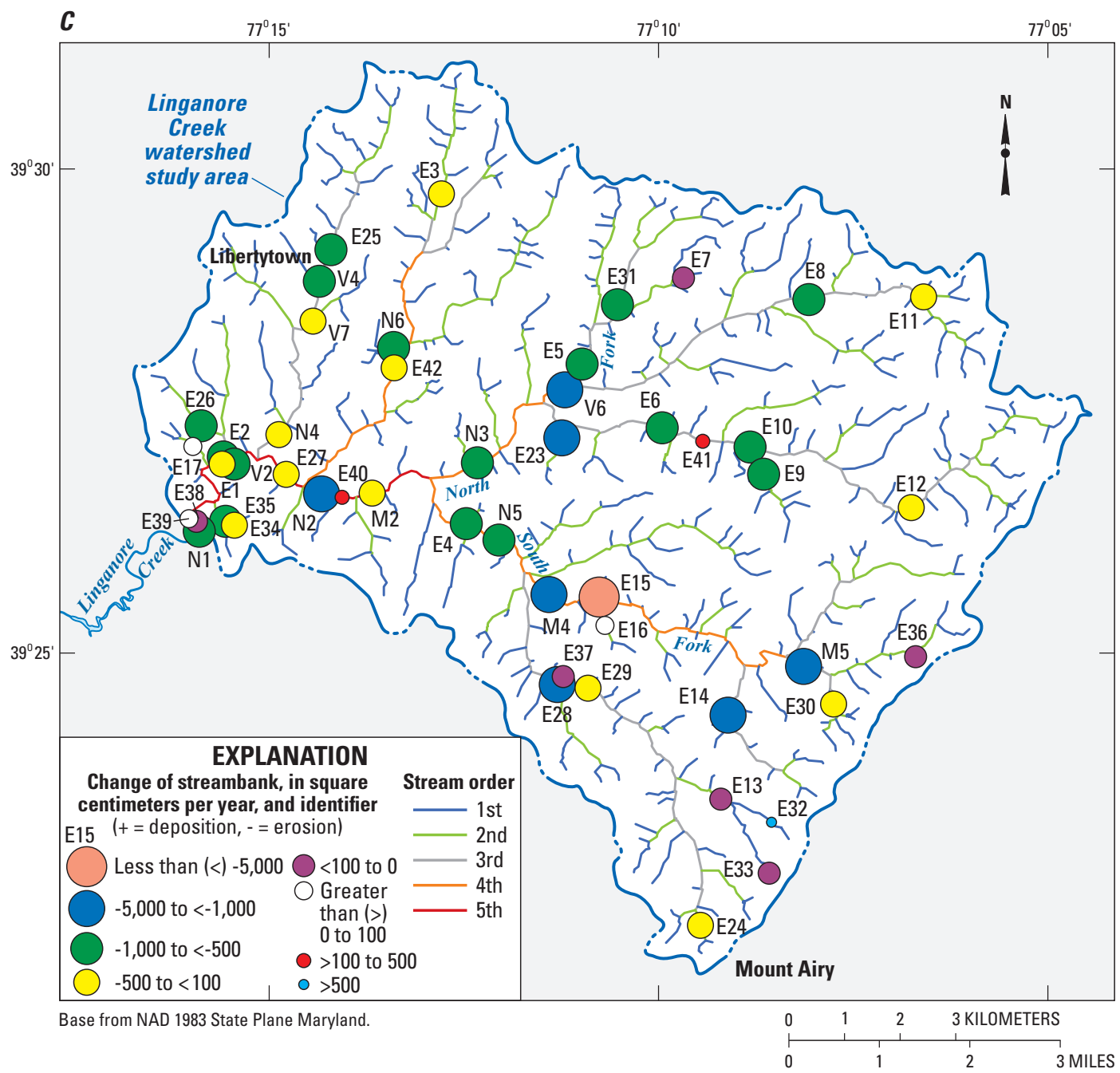

Figure 17. (A) Streambank changes determined through bank pin measurements, and reach-averaged streambank changes, $(B)$ centimeters per year, and $(C)$ square centimeters per year in Linganore Creek watershed study area, Frederick County, Maryland, August 11, 2008 through December 24, 2010.-Continued

\section{Sediment Storage in Ponds}

One hundred ninety five ponds were identified in the Linganore Creek watershed (figs. 9 and 21; appendix 11). Of the 195 ponds, the majority 174 ( 89 percent) were classified as farm ponds and 20 (10 percent) were classified as stormwater and sediment-retention ponds (appendix 11). One pond was classified as recreational. Farm ponds can serve several purposes including erosion control, water source, ecosystems habitat, nutrient detention, and recreation (U.S. Department of Agriculture, Natural Resources Conservation Service, 2006). Stormwater and sediment-retention ponds are typically found in the urbanized area near the town of Mount Airy (fig. 1), and were constructed downgradient of housing divisions to capture stormwater runoff and sediment.
The majority of ponds, 59 percent $(\mathrm{n}=116)$, are on zero order channels. These are channels that may be described as swales or vegetated valleys that do not contain a well-defined channel. Thirty-five percent $(n=68)$ of the ponds were on 1 st order streams and 3 percent $(n=6)$ were on 2 nd order streams. The drainage areas to the 195 ponds ranged from 0.09 to 232 hectares (ha) with the majority ( $\mathrm{n}=80,41$ percent) draining from 1 to $10 \mathrm{ha}$, and 40 percent $(\mathrm{n}=78)$ draining greater than 10 to 100 ha (fig. 9). The combined drainage area of all ponds is 2,411 ha, which is 16 percent of the total Linganore drainage area. Ponds intercept flowpaths in a large part of the Linganore Creek watershed and are important sites for sediment storage.

The area $\left(\mathrm{m}^{2}\right)$ of agriculture and forest and the length of each stream order draining to each pond was determined by 


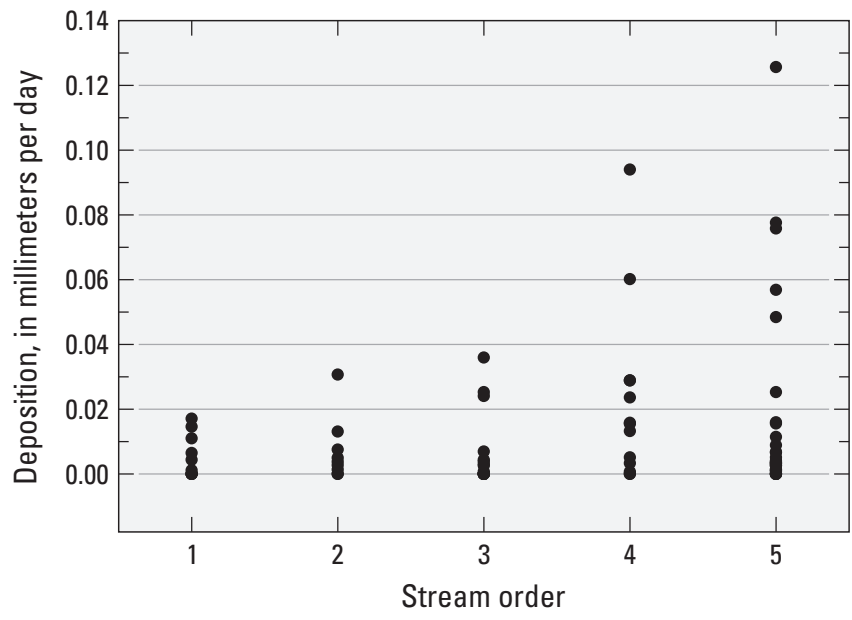

Figure 18. Deposition measured on individual flood-plain pads ( $n=79$ ) for Linganore Creek, August 1, 2008-December 31, 2010, displayed by stream order.

Table 10. Results of forward stepwise regression on explanatory variables used to describe response variable of flood-plain deposition.

[cm, centimeters; $\mathrm{m}^{2}$, square meters]

\begin{tabular}{ccccc}
\hline Step & $\begin{array}{c}\text { Explanatory variable } \\
\text { entered }\end{array}$ & $\begin{array}{c}\text { Modeled } \\
\mathbf{R}^{2}\end{array}$ & F Value & Pr $>\mathbf{F}$ \\
\hline 1 & $\begin{array}{c}\text { Log distance of pad } \\
\text { from edge of stream } \\
(\mathrm{cm})\end{array}$ & 0.08 & 6.83 & 0.011 \\
\hline 2 & $\begin{array}{c}\text { Log contributing } \\
\left.\text { area to pad (m }{ }^{2}\right)\end{array}$ & 0.18 & 9.23 & 0.003 \\
\hline 3 & $\begin{array}{c}\text { Elevation of pad } \\
\text { above channel } \\
\text { thalweg }(\mathrm{cm})\end{array}$ & 0.28 & 10.01 & 0.002 \\
\hline
\end{tabular}

use of a GIS. The total mass of sediment that is delivered and stored in these ponds annually was estimated using the upland rates of erosion and deposition using the ${ }^{137} \mathrm{Cs}$ approach (table 12), and erosion and deposition rates from the channel beds, streambanks, and flood plains for different stream orders (tables 8, 9, 11). Using the line of best-fit from the relation developed in figure 10, a pond trap efficiency was determined for each pond. The total mass of sediment transported to all ponds (sum of all $P_{u s}$ in equation 18) was $-108.548 \times 10^{5} \mathrm{~kg} / \mathrm{yr}$ $\left(-108.550 \times 10^{5} ;-108.544 \times 10^{5}\right)$ (table 13). Eighty five percent $\left(-93.213 \times 10^{5} \mathrm{~kg} / \mathrm{yr}\left(-95.585 \times 10^{5} ;-90.078 \times 10^{5}\right)\right) ; P_{d e p}$ in equation 19) of the eroded fine-grained sediment was stored in ponds (table 13) and $-1.695 \times 10^{6} \mathrm{~kg} / \mathrm{yr}\left(-1.969 \times 10^{6} ;-1.329 \mathrm{x}\right.$ $\left.10^{6}\right)\left(P_{d s}\right.$ in equation 20) was transported past the ponds.

\section{Limitations and Uncertainty in the Sediment Budget}

Uncertainty in the measurements used to construct the sediment budget included laboratory uncertainty, measurement error, and statistical uncertainties. Analytical uncertainty in laboratory analysis for ${ }^{137} \mathrm{Cs}$ and for tracers used in sediment fingerprinting are shown in table 14. Uncertainty in measurement and laboratory analysis is shown in table 14 and appendixes 12 and 13. Based on errors in the closure of channel surveys, the uncertainty in surveying channel beds is plus or minus $0.6 \mathrm{~cm}$. Based on readings from five observers each measuring two banks, measurement uncertainty in bank erosion pin measurements was plus or minus $0.8 \mathrm{~cm}$ (appendix 12). Based on readings from five observers each measuring sediment deposition on flood-plain pads, measurement uncertainty in flood-plain clay pad measurements was plus or minus $1.5 \mathrm{~mm}$ (appendix 13). Uncertainty in the computation of the sediment budget is presented as lower (LCL) and upper (UCL) confidence intervals, shown next to the average value in parentheses (AVERAGE LCL; UCL) presented in the next section.

\section{Sediment Budget Results}

Results from the channel surveys (table 8) showed that channel beds eroded $-7.86 \times 10^{4} \mathrm{~kg} / \mathrm{yr}\left(-2.93 \times 10^{5} ; 1.29 \times 10^{5}\right.$ $\mathrm{kg} / \mathrm{yr})$ and deposited $7.82 \times 10^{5} \mathrm{~kg}\left(-1.26 \times 10^{5} ; 1.80 \times 10^{6}\right)$ of fine-grained sediment (tables 15 and 16), resulting in a net deposition of $7.03 \times 10^{5} \mathrm{~kg} / \mathrm{yr}\left(-1.26 \times 10^{5}\right.$ to $\left.1.80 \times 10^{6} \mathrm{~kg} / \mathrm{yr}\right)$ of fine sediment.

Results of the field measurements on streambanks (table 9) indicated that $-6.44 \times 10^{6} \mathrm{~kg} / \mathrm{yr}\left(-8.76 \times 10^{6}\right.$ to $-4.84 \times 10^{6} \mathrm{~kg} / \mathrm{yr}$ ) of fine sediment was eroded from streambanks and $1.04 \times 10^{6} \mathrm{~kg} / \mathrm{yr}\left(-3.09 \times 10^{6} ; 6.72 \times 10^{5} \mathrm{~kg} / \mathrm{yr}\right)$ of fine sediment was deposited in streambanks (tables 15 and 16), resulting in a net erosion from streambanks of $-5.40 \times 10^{6}$ $\mathrm{kg} / \mathrm{yr}\left(-8.09 \times 10^{6}\right.$ to $\left.5.01 \times 10^{5} \mathrm{~kg} / \mathrm{yr}\right)$ (table 15). Results of flood-plain deposition measured from clay pads and the regression model used to estimate flood-plain deposition (tables 10 and 11; appendix 7b) showed net deposition of fine sediment on flood plains of $5.18 \times 10^{6} \mathrm{~kg}\left(2.38 \times 10^{6}\right.$ to $8.07 \times$ $10^{6} \mathrm{~kg} / \mathrm{yr}$ ) (tables 15 and 16).

The ${ }^{137} \mathrm{Cs}$ approach used to determine erosion and deposition on uplands (agriculture and forest) (table 12; appendixes 8 and 9), estimated the total amount of fine sediment eroded from upland areas was $-5.68 \times 10^{7} \mathrm{~kg} / \mathrm{yr}\left(-6.71 \times 10^{7}\right.$ to -4.73 $x 10^{7} \mathrm{~kg} / \mathrm{yr}$ ) (tables 15 and 16). The greatest contribution of sediment from any upland source was from agriculture $\left(-5.48 \times 10^{7} \mathrm{~kg} / \mathrm{yr} ;-6.51 \times 10^{7} ;-4.53 \times 10^{7} \mathrm{~kg} / \mathrm{yr}\right)$, which was 10 times the amount of fine-grained sediment that was transported out of the basin (tables 14 and 15). Forested areas eroded $-2.03 \times 10^{6} \mathrm{~kg} / \mathrm{yr}\left(-2.0303 \times 10^{6} \mathrm{~kg} / \mathrm{yr} ;-2.0274 \times 10^{6}\right.$ $\mathrm{kg} / \mathrm{yr})$ (table 15). 
Table 11. Summary of modeled flood-plain deposition at surveyed cross sections. (Deposition rates are based on regression model [Appendix 7]).

[10CI, 10-percent confidence interval; 90CI, 90-percent confidence interval; $\mathrm{cm}^{2} / \mathrm{yr}$, square centimeters per year]

\begin{tabular}{|c|c|c|c|c|}
\hline $\begin{array}{l}\text { Reach identifier } \\
\text { (fig. 6) }\end{array}$ & Date from & Date to & $\begin{array}{c}\text { Stream } \\
\text { order }\end{array}$ & $\begin{array}{l}\text { Modeled deposition } \\
\left(\mathrm{cm}^{2} / \mathrm{yr}\right)\end{array}$ \\
\hline E33 & $3 / 27 / 2009$ & $12 / 21 / 2010$ & 1 & 80.8 \\
\hline E34 & $3 / 30 / 2009$ & $11 / 8 / 2010$ & 1 & 67.2 \\
\hline E36 & $6 / 1 / 2009$ & $12 / 21 / 2010$ & 1 & 17.9 \\
\hline E37 & $7 / 22 / 2009$ & $11 / 3 / 2010$ & 1 & 6.38 \\
\hline $\mathrm{E} 40$ & $3 / 24 / 2010$ & $11 / 8 / 2010$ & 1 & 10.2 \\
\hline E17 & $8 / 12 / 2008$ & $10 / 28 / 2010$ & 2 & 111 \\
\hline E24 & 9/9/2008 & $10 / 20 / 2010$ & 2 & 66.5 \\
\hline E35 & $3 / 30 / 2009$ & $11 / 8 / 2010$ & 2 & 108 \\
\hline Average 1st and 2 nd orders (10CI; 90CI) & & & & $59(35.7 ; 81.8)$ \\
\hline E25 & $9 / 12 / 2008$ & $10 / 20 / 2010$ & 3 & 726 \\
\hline E31 & $2 / 6 / 2009$ & $10 / 25 / 2010$ & 3 & 265 \\
\hline M5 & 3/9/2009 & $10 / 15 / 2010$ & 3 & 312 \\
\hline N4 & $8 / 27 / 2008$ & $10 / 28 / 2010$ & 3 & 1,043 \\
\hline V4 & $12 / 17 / 2008$ & $11 / 2 / 2010$ & 3 & 606 \\
\hline V7 & $12 / 17 / 2008$ & $11 / 1 / 2010$ & 3 & 100 \\
\hline Average 3rd order (10CI; 90CI) & & & & $508(296 ; 722)$ \\
\hline N3 & $8 / 19 / 2008$ & $10 / 26 / 2010$ & 4 & 3,308 \\
\hline N6 & $9 / 23 / 2008$ & $10 / 26 / 2010$ & 4 & 740 \\
\hline V6 & $1 / 23 / 2009$ & $11 / 1 / 2010$ & 4 & 1,072 \\
\hline M2 & $3 / 10 / 2009$ & $10 / 18 / 2010$ & 5 & 512 \\
\hline $\mathrm{N} 1$ & $8 / 12 / 2008$ & $10 / 28 / 2010$ & 5 & 873 \\
\hline $\mathrm{N} 2$ & $8 / 18 / 2008$ & $10 / 19 / 2010$ & 5 & 3,753 \\
\hline N5 & $9 / 23 / 2008$ & $10 / 19 / 2010$ & 5 & 1,740 \\
\hline $\mathrm{V} 2$ & $12 / 15 / 2008$ & $11 / 2 / 2009$ & 5 & 575 \\
\hline Average 4th and 5th orders (10CI; 90CI) & & & & $1,572(887 ; 2,293)$ \\
\hline
\end{tabular}

Estimates of the amount of fine-grained sediment stored annually in ponds using the sediment-budget measurements in the areas draining to the ponds (table 13, appendix 11) and the trap-efficiency relation shown in figure 10 indicated that sediment storage was $93.213 \times 10^{5} \mathrm{~kg} / \mathrm{yr}\left(90.078 \times 10^{5}\right.$;

$95.585 \times 10^{5}$ ) of fine sediment. The amount of fine-grained sediment stored in ponds is 1.7 times the total amount of finegrained sediment transported annually out of the basin (5,454 Mg/yr) (table 3).

The net amount (erosion minus deposition) of finegrained sediment determined from the sediment budget was erosion of $-4.70 \times 10^{7} \mathrm{~kg} / \mathrm{yr}\left(-4.98 \times 10^{7} ;-4.10 \times 10^{7}\right)$

(table 16). The fine-grained sediment (silt and clay) delivered out of the Linganore Creek watershed measured at the USGS streamflow-gaging station was $-5.45 \times 10^{6} \mathrm{~kg} / \mathrm{yr}$ (table 3 ; table 15). The difference in the export of fine-grained sediment determined from the sediment budget compared to the measured sediment load is $4.15 \times 10^{7} \mathrm{~kg} / \mathrm{yr}\left(3.87 \times 10^{7} ; 4.75 \times 10^{7}\right.$ $\mathrm{kg} / \mathrm{yr}$ ) (table 16), indicating that the sediment budget overpredicted the export of sediment by 8.6 times the measured value. To balance the sediment budget, the error of $4.15 \times 10^{7} \mathrm{~kg} / \mathrm{yr}$ of sediment is assumed to be fine-grained sediment that went into storage at locations in the Linganore Creek watersheds that were not adequately measured in this study.

Expressing the fine-grained sediment budget in terms of equation 8 using the sediment budget measurements $(I \pm \Delta S)$, the fluvial sediment recorded at the gage as the export $(O)$ and incorporating the error in the sediment budget (table 16) is: 


$$
I \pm \Delta S=O
$$

where

$$
\begin{aligned}
I= & -6.33 \times 10^{7} \mathrm{~kg} / \mathrm{yr}\left(-6.56 \times 10^{7} ;-6.17 \times 10^{7}\right. \\
& \mathrm{kg} / \mathrm{yr}) ; \\
\Delta S= & 5.78 \times 10^{7} \mathrm{~kg} / \mathrm{yr}\left(5.46 \times 10^{7} ; 6.62 \times 10^{7}\right. \\
& \mathrm{kg} / \mathrm{yr}) ; \text { and } \\
O \quad= & -5.45 \times 10^{6} \mathrm{~kg} / \mathrm{yr} .
\end{aligned}
$$

and $-6.33 \times 10^{7} \mathrm{~kg} / \mathrm{yr}$ of sediment is eroded from all geomorphic elements and $5.78 \times 10^{7} \mathrm{~kg} / \mathrm{yr}$ is deposited on uplands, ponds, flood plains, and channels, resulting in a net transport out of the watershed of $-5.45 \times 10^{6} \mathrm{~kg} / \mathrm{yr}$. Important storage sites of sediment included ponds, which stored 15 percent $\left(9.32 \times 10^{6} \mathrm{~kg} / \mathrm{yr}\right)$, and flood plains, which stored 8 percent $\left(5.18 \times 10^{6} \mathrm{~kg} / \mathrm{yr}\right)$ of all eroded sediment $\left(6.33 \times 10^{7} \mathrm{~kg} / \mathrm{yr}\right)$ (table 16).

Balancing the sediment budget indicated that a large amount of fine-grained sediment in storage was not accounted for in the sediment-budget measurements (table 16). Errors

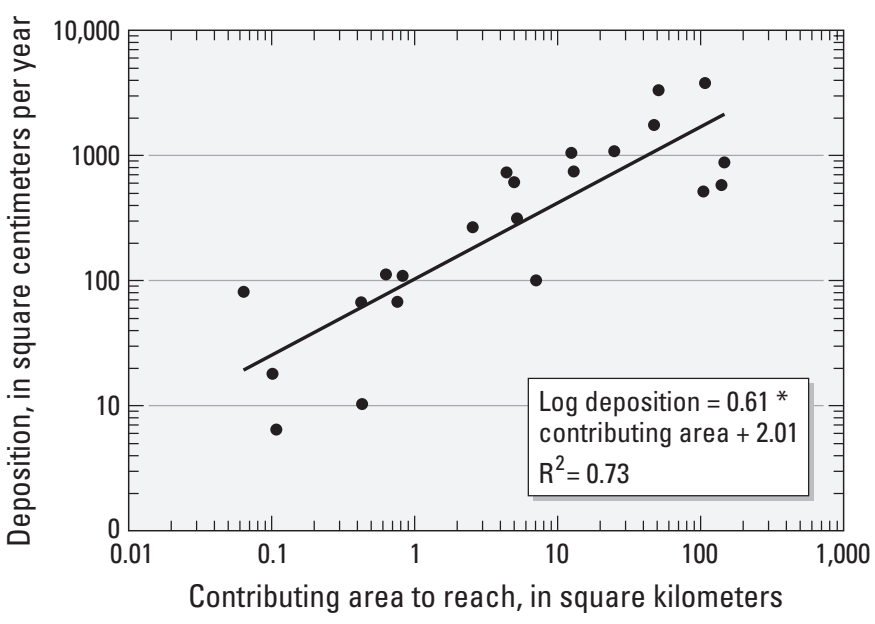

Figure 19. Relation of reach-averaged flood-plain deposition compared to contributing area, Linganore Creek, Maryland. (The reach-averaged flood-plain deposition is based on a regression model of flood-plain deposition [table 10].)

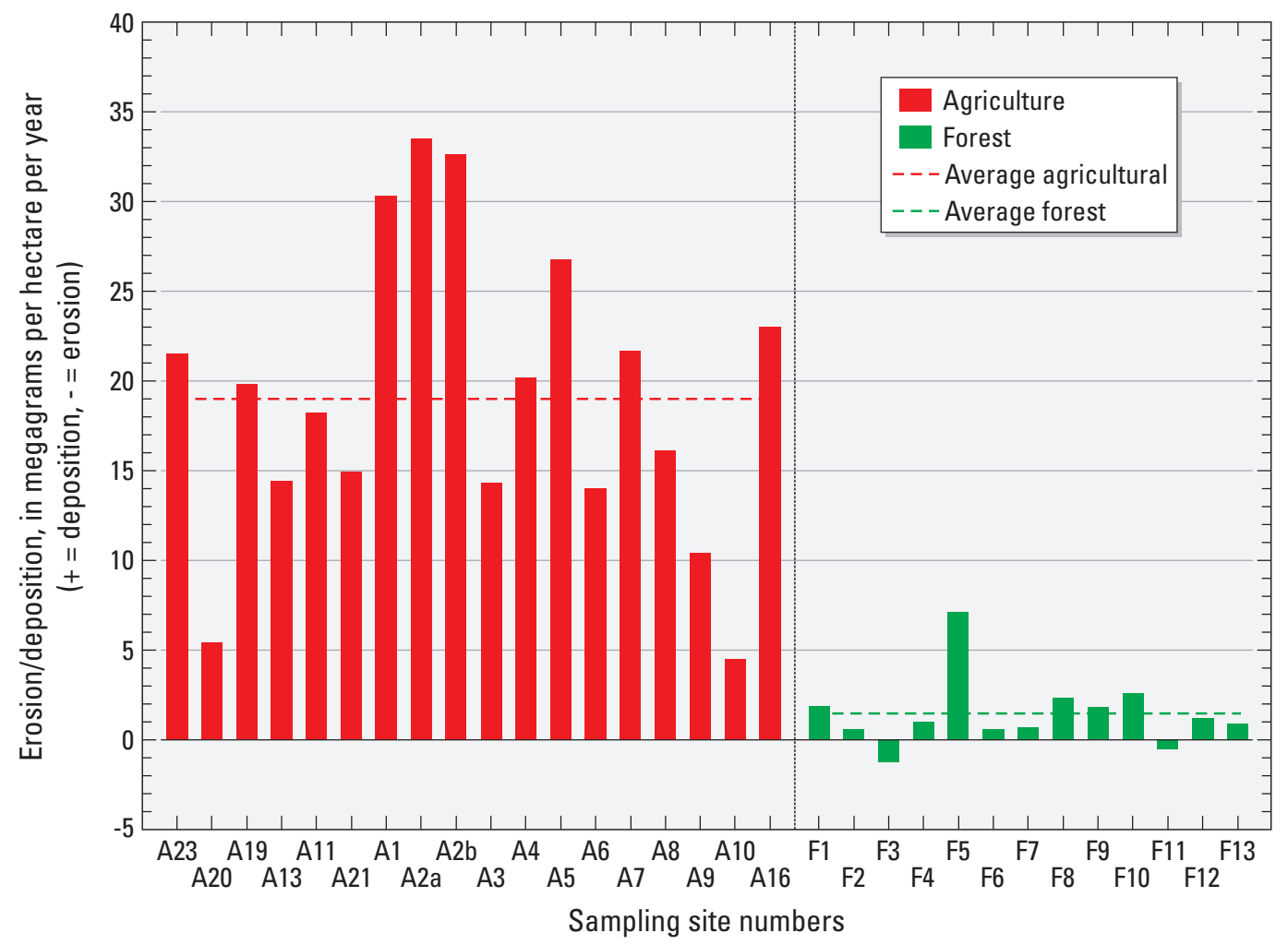

Figure 20. Summary of erosion on agricultural and forested areas using the Cesium-137 method, Lake Linganore, Maryland. 
Table 12. Agricultural and forest rates of erosion using the Cesium-137 method.

[\%, percent; Mg/ha, megagrams per hectare; 10CI, 10-percent confidence interval; 90CI, 90-percent confidence interval]

\begin{tabular}{|c|c|c|c|}
\hline \multicolumn{4}{|c|}{ Agicultural rates of erosion } \\
\hline $\begin{array}{l}\text { Map identifier } \\
\text { (fig. 7) }\end{array}$ & Land type & $\begin{array}{c}\text { Net erosion } \\
\text { (Mg/ha) } \\
\text { (+ = deposition; - = erosion) }\end{array}$ & $\begin{array}{l}\text { Percent fines } \\
\text { (silt and clay) }\end{array}$ \\
\hline $\mathrm{A} 1 *$ & Hay & -30.3 & \\
\hline $\mathrm{A} 2 \mathrm{a} *$ & Cropland corn & -33.5 & \\
\hline A4* & Pasture hay & -20.2 & 42.2 \\
\hline $\mathrm{A} 5^{*}$ & Cropland corn $(40 \%)$, hay pasture $(40 \%)$ & -26.8 & 39.7 \\
\hline A6* & Pasture warm season grass & -14.0 & 38.1 \\
\hline $\mathrm{A} 7 *$ & Crop (corn $70 \%$, pasture $30 \%$ ) & -21.7 & 33.9 \\
\hline A11 & Pasture/alfalfa & -18.2 & 32.8 \\
\hline A13 & Cropland corn/oats cover crop & -14.4 & 31.4 \\
\hline A16* & Cropland corn & -23.0 & 35.5 \\
\hline A19 & Pasture/hay & -19.8 & 44.0 \\
\hline A20 & Pasture/hay & -5.4 & 41.0 \\
\hline A21 & Cropland corn/oats & -14.9 & 30.6 \\
\hline A23 & Cropland corn/oats cover crop & -21.5 & 56.2 \\
\hline \multicolumn{4}{|c|}{ Sites sampled only for grain size } \\
\hline A 12 & Cropland soy & & 53.2 \\
\hline A22 & Pasture/hay & & 41.0 \\
\hline Average (10CI; 90CI) & & $-19.0(-22.3 ; 16.0)$ & $38.2(35.4 ; 41.2)$ \\
\hline
\end{tabular}

* Soil cores for Cesium-137 analysis obtained from Clune and others (2010).

in sediment budgets are commonly reported in the literature (Gellis and others, 2012; Kondolf and Matthews, 1991) and can be related to a number of factors. The error in the sediment budget for Linganore Creek, which did not account for $4.15 \times 10^{7} \mathrm{~kg} / \mathrm{yr}$ of fine-grained sediment, may be due to overestimates of erosion or underestimates of deposition.

Overestimation of erosion may be related to the period represented by the measurements. The ${ }^{137} \mathrm{Cs}$ approach estimates erosion since the 1950 s, a period of over 50 years. The channel and flood-plain measurements in the sediment budget were taken over a 3 -year period. Large storms such as hurricanes, which cause significant amounts of erosion that would have occurred over the 50 years, would be reflected in the ${ }^{137} \mathrm{Cs}$ estimates. Another factor that would lead to higher erosion rates in agricultural areas over the historical period compared to the period of study would be the recent implementation of agricultural conservation practices to reduce erosion. Practices such as no-till, contour plowing, and vegetated buffers can reduce soil erosion. If these practices were recently established on agricultural lands, the reduction in erosion may not be reflected in the ${ }^{137} \mathrm{Cs}$-derived estimates of long-term erosion. 
Table 12 Agricultural and forest rates of erosion using the Cesium-137 method.-Continued

[Mg/ha, megagrams per hectare; 10CI, 10-percent confidence interval; 90CI, 90-percent confidence interval]

\begin{tabular}{|c|c|c|c|}
\hline \multicolumn{4}{|c|}{ Forest rates of erosion } \\
\hline $\begin{array}{l}\text { Map identifier } \\
\text { (fig. 7) }\end{array}$ & Land type & $\begin{array}{c}\text { Net erosion } \\
\text { (Mg/ha) } \\
\text { (+ = deposition; - = erosion) }\end{array}$ & $\begin{array}{l}\text { Percent fines } \\
\text { (silt and clay) }\end{array}$ \\
\hline F1 & Forest & -1.9 & 53.3 \\
\hline F2 & Forest & -0.6 & 42.3 \\
\hline $\mathrm{F} 3$ & Forest & 1.3 & \\
\hline $\mathrm{F} 4$ & Forest & -1.0 & 13.1 \\
\hline F5 & Forest & -7.1 & \\
\hline F6 & Forest & -0.6 & 44.3 \\
\hline F7 & Forest & -0.7 & \\
\hline F8 & Forest & -2.3 & 26.0 \\
\hline F9 & Forest & -1.8 & \\
\hline F10 & Forest & -2.6 & 50.9 \\
\hline F11 & Forest & 0.5 & \\
\hline F12 & Forest & -1.2 & 18.2 \\
\hline F13 & Forest & -0.9 & 45.0 \\
\hline \multicolumn{4}{|c|}{ Sites sampled only for grain size } \\
\hline F102 & Forest & 56.0 & \\
\hline F14 & Forest & & 53.3 \\
\hline Average (10CI; 90CI) & & $-1.45(-2.38 ;-0.65)$ & $40.2(32.3 ; 48.0)$ \\
\hline
\end{tabular}

Underestimation of storage can occur when all storage elements in the watershed are not adequately measured. Ponds were not specifically monitored and could be trapping more sediment than was estimated. Areas where deposition was not measured include the toe slopes or the bottom of slopes at agricultural areas. These are typically vegetated areas below the agricultural fields that were downgradient of the ${ }^{137} \mathrm{Cs}$ measurements and often past the area that was defined as the active flood plain (fig. 5). These could be sites where sediment is being deposited. Future studies in the Chesapeake Bay watershed may quantify deposition rates in these geomorphic zones.

Summarizing the sediment budget indicated that sediment eroded from agricultural lands was 86 percent of the total sediment eroded from all geomorphic units, streambanks eroded 10 percent, and forests eroded 3 percent of all sediment. These percentages of eroded sediment from the sediment budget differ from the total load weighted results using sediment fingerprinting (table 7), which showed that streambanks contributed 52 percent, agriculture 45 percent,

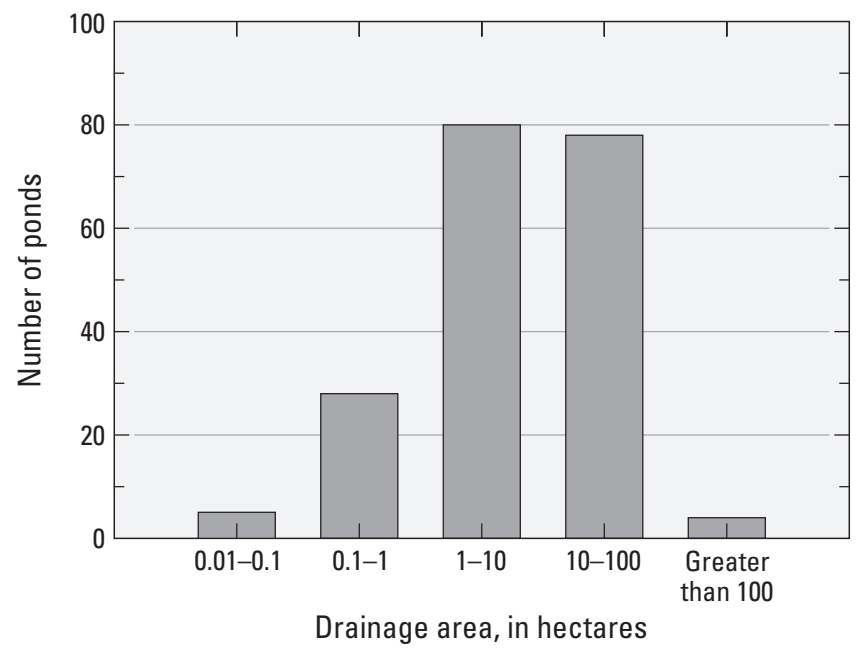

Figure 21. Distribution of ponds by area draining to ponds, Linganore Creek, Maryland. 
Table 13. Summary of erosion and deposition in contributing areas to ponds from the channel bed, channel banks, flood plains, and upland areas (agriculture and forest). (The total sediment in pond storage is based on the delivered sediment multiplied by the trap efficiency for each pond using equation 19 [Appendix 11].)

[m, meters; kg/yr, kilograms per year; ha, hectares; 10CI, 10-percent confidence interval; 90CI, 90-percent confidence interval; + = deposition, - = erosion]

\begin{tabular}{|c|c|c|c|c|c|c|}
\hline & $\begin{array}{l}\text { 1st order bed } \\
\text { erosion }\end{array}$ & 2nd order bed & 1st order bank & 2nd order bank & $\begin{array}{l}\text { 1st order } \\
\text { flood plain }\end{array}$ & $\begin{array}{l}\text { 2nd order } \\
\text { flood plain }\end{array}$ \\
\hline $\begin{array}{l}\text { Total length channel above ponds } \\
\text { (m) }\end{array}$ & 21,270 & 5,095 & 21,270 & 5,095 & & \\
\hline $\begin{array}{l}\text { Bed or bank sediment delivered to } \\
\text { ponds }(\mathrm{kg} / \mathrm{yr})(10 \mathrm{CI} ; 90 \mathrm{CI})\end{array}$ & $\begin{array}{c}-2,062 \\
(-3839 ;-269)\end{array}$ & $\begin{array}{c}-3,300 \\
(-9925 ; 3210)\end{array}$ & $\begin{array}{l}18.048 \times 10^{4} \\
\left(13.494 \times 10^{4}\right. \\
\left.23.497 \times 10^{4}\right)\end{array}$ & $\begin{array}{c}-12.364 \times 10^{4} \\
\left(-15.625 \times 10^{4}\right. \\
\left.-9.054 \times 10^{4}\right)\end{array}$ & & \\
\hline $\begin{array}{l}\text { Total flood-plain deposition above } \\
\text { ponds }(\mathrm{kg} / \mathrm{yr})\end{array}$ & Agriculture & Forest & & & & \\
\hline Area drained to ponds (ha) & 1,499 & 510 & & & & \\
\hline $\begin{array}{l}\text { Upland sediment delivered to ponds } \\
\qquad(\mathrm{kg} / \mathrm{yr})(10 \mathrm{CI} ; 90 \mathrm{CI})\end{array}$ & $\begin{array}{l}-108.548 \times 10^{5} \\
\left(-108.550 \times 10^{5}\right. \\
\left.-108.544 \times 10^{5}\right)\end{array}$ & $\begin{array}{l}-29.845 \times 10^{4} \\
\left(-29.849 \times 10^{4}\right. \\
\left.-29.836 \times 10^{4}\right)\end{array}$ & & & & \\
\hline
\end{tabular}

Table 14. Limitation and uncertainty in laboratory analysis and field measurements used in the sediment budget and sediment fingerprinting analysis. [Quantitative analysis is shown as $+/$ - where the relative error cannot be quantified.]

[ $\mu \mathrm{g} / \mathrm{g}$, micrograms per gram; mg/g, milligrams per gram; Bq/g, becquerels per gram; cm, centimeters; mm, millimeters; \%o, per mil; \%, percent; GIS, Geographic Information System]

\begin{tabular}{|c|c|c|c|}
\hline Laboratory elemental analysis & Laboratory analytical error & Laboratory elemental analysis & Laboratory analytical error \\
\hline Boron $(B)(\mu \mathrm{g} / \mathrm{g})$ & \pm 19 & Lithium $(\mathrm{Li})(\mu \mathrm{g} / \mathrm{g})$ & \pm 13 \\
\hline Vanadium $(V)(\mu g / g)$ & \pm 25 & Calcium $(\mathrm{Ca})(\mathrm{mg} / \mathrm{g})$ & \pm 4 \\
\hline Cobalt $(\mathrm{Co})(\mu \mathrm{g} / \mathrm{g})$ & \pm 3 & Potassium (K) (mg/g) & \pm 11 \\
\hline Nickel $(\mathrm{Ni})(\mu \mathrm{g} / \mathrm{g})$ & \pm 16 & Aluminum (Al) (mg/g) & \pm 26 \\
\hline Molybdenum (Mo) ( $\mu \mathrm{g} / \mathrm{g})$ & \pm 0.4 & Titanium (Ti) (mg/g) & \pm 0.6 \\
\hline Antimony $(\mathrm{Sb})(\mu \mathrm{g} / \mathrm{g})$ & \pm 0.6 & $\mathrm{C} 13(\%)$ & \pm 0.5 \\
\hline Arsenic (As) $(\mu \mathrm{g} / \mathrm{g})$ & \pm 3 & N15 (\%o) & \pm 0.5 \\
\hline Lead $(\mathrm{Pb})(\mu \mathrm{g} / \mathrm{g})$ & \pm 4 & Cesium $137(\mathrm{~Bq} / \mathrm{g})$ & $+/-1.67 \times 10^{-4}$ to $1.33 \times 10^{-3}(\mathrm{~Bq} / \mathrm{g})$ \\
\hline Bank pins & $+/-0.8 \mathrm{~cm}$ & $\begin{array}{c}\text { Discharge } \\
\text { (Sauer and Meyer, 1992) }\end{array}$ & $+/-3$ to $6 \%$ \\
\hline Other possible errors & Measurement error & Other possible errors & Measurement error \\
\hline $\begin{array}{l}\text { GIS uncertainty in outputs of } \\
\text { stream length, land-use } \\
\text { percentages }\end{array}$ & + or - & $\begin{array}{l}\text { Statistical interpretations- } \\
\text { regression analysis on flood-plain } \\
\text { deposition and pond trap efficiency }\end{array}$ & + or - \\
\hline
\end{tabular}


Table 15. Final construction sediment budget based on field measurements of channel banks, channel beds, and flood plains, Cesium-137 inventories on agriculture and forested areas, storage of sediment estimated in ponds, and net sediment budget. The sum of sediment eroding from these elements is compared to the total of fine-grained sediment transported past the U.S. Geological Survey streamflow-gaging station.

[USGS, U.S. Geological Survey; kg/yr, kilograms per year; \%, percent]

\begin{tabular}{|c|c|c|c|}
\hline \multicolumn{4}{|c|}{ Channel banks } \\
\hline$S_{k}$ in equation 22 & $\begin{array}{l}\text { Net streambank contribution } \\
\text { (kg/yr) } \\
\text { (+ = deposition; - = erosion) }\end{array}$ & $\begin{array}{l}\text { Lower confidence interval } \\
\qquad(10 \%)\end{array}$ & $\begin{array}{l}\text { Upper confidence interval } \\
\qquad(\mathbf{9 0 \% )}\end{array}$ \\
\hline 1 & $1.04 \times 10^{6}$ & $-3.09 \times 10^{5}$ & $6.72 \times 10^{6}$ \\
\hline 2 & $-1.56 \times 10^{6}$ & $-2.49 \times 10^{6}$ & $-7.46 \times 10^{5}$ \\
\hline 3 & $-2.33 \times 10^{6}$ & $-3.00 \times 10^{6}$ & $-1.66 \times 10^{6}$ \\
\hline 5 & $-3.56 \times 10^{5}$ & $-5.11 \times 10^{5}$ & $-2.41 \times 10^{5}$ \\
\hline Total of all stream orders & $-5.40 \times 10^{6}$ & $-8.09 \times 10^{6}$ & $5.01 \times 10^{5}$ \\
\hline \multicolumn{4}{|c|}{ Channel beds } \\
\hline$S_{b}$ in equation 22 & $\begin{array}{l}\text { Net bed contribution (kg/yr) } \\
\text { (+ = deposition; - = erosion) }\end{array}$ & $\begin{array}{c}\text { Confidence interval } \\
(10 \%)\end{array}$ & $\begin{array}{l}\text { Confidence interval } \\
(90 \%)\end{array}$ \\
\hline 3 & $-2.52 \times 10^{4}$ & $-1.24 \times 10^{5}$ & $6.64 \times 10^{4}$ \\
\hline 4 & $5.77 \times 10^{5}$ & $-2.79 \times 10^{5}$ & $1.53 \times 10^{6}$ \\
\hline 5 & $2.05 \times 10^{5}$ & $-9.91 \times 10^{4}$ & $5.45 \times 10^{5}$ \\
\hline Total of all stream orders & $7.03 \times 10^{5}$ & $-7.90 \times 10^{5}$ & $2.32 \times 10^{6}$ \\
\hline \multicolumn{4}{|c|}{ Flood plains } \\
\hline$F_{p}$ in equation 22 & $\begin{array}{l}\text { Net flood-plain contribution } \\
\text { (kg/yr) } \\
\text { (+ = deposition; - = erosion) }\end{array}$ & $\begin{array}{l}\text { Confidence interval } \\
\qquad(10 \%)\end{array}$ & $\begin{array}{l}\text { Confidence interval } \\
(90 \%)\end{array}$ \\
\hline 1 & $5.08 \times 10^{5}$ & $2.36 \times 10^{5}$ & $7.87 \times 10^{5}$ \\
\hline 2 & $2.62 \times 10^{5}$ & $1.24 \times 10^{5}$ & $4.14 \times 10^{5}$ \\
\hline
\end{tabular}


Table 15. Final construction sediment budget based on field measurements of channel banks, channel beds, and flood plains, Cesium-137 inventories on agriculture and forested areas, storage of sediment estimated in ponds, and net sediment budget. The sum of sediment eroding from these elements is compared to the total of fine-grained sediment transported past the U.S. Geological Survey streamflow-gaging station.-Continued

[USGS, U.S. Geological Survey; kg/yr, kilograms per year; \%, percent]

\begin{tabular}{|c|c|c|c|}
\hline$A_{g}$ and $F_{r}$ in equation 22 & Upland erosion (kg/yr) & Confidence interval (10\%) & Confidence interval (90\%) \\
\hline Agriculture & $-5.48 \times 10^{7}$ & $-6.51 \times 10^{7}$ & $-4.53 \times 10^{7}$ \\
\hline Forest & $-2.03 \times 10^{6}$ & $-2.0303 \times 10^{6}$ & $-2.0274 \times 10^{6}$ \\
\hline Sum & $-5.68 \times 10^{7}$ & $-6.71 \times 10^{7}$ & $-4.73 \times 10^{7}$ \\
\hline \multicolumn{4}{|c|}{ Storage of sediment estimated in ponds } \\
\hline$P_{d}$ in equation 22 & Pond Storage & Confidence interval (10\%) & Confidence interval $(90 \%)$ \\
\hline Total & $93.213 \times 10^{5}$ & $95.585 \times 10^{5}$ & $90.078 \times 10^{5}$ \\
\hline \multicolumn{4}{|c|}{ Net sediment budget } \\
\hline \multirow[t]{2}{*}{$T_{z}$ in equation 22} & Net sediment Budget (kg/yr) & Confidence interval (10\%) & Confidence interval (90\%) \\
\hline & $-4.70 \times 10^{7}$ & $-4.98 \times 10^{7}$ & $-4.10 \times 10^{7}$ \\
\hline \multicolumn{4}{|c|}{ Sum of sediment eroding compared to fine-grained sediment transported past USGS streamflow-gaging station } \\
\hline \multicolumn{4}{|c|}{$\begin{array}{l}\text { Fine-grained sediment transport } \\
\text { measured at USGS streamflow } \\
\text { gaging-station }(\mathrm{kg} / \mathrm{yr})\end{array}$} \\
\hline & $-5.45 \times 10^{6}$ & & \\
\hline
\end{tabular}

Table 16. Summary of sediment budget in terms of erosion (input), storage, and delivery (equation 8).

[kg/yr, kilograms per year; 10CI, 10-percent confidence interval; 90CI, 90-percent confidence interval; + = deposition or storage, - = erosion]

\begin{tabular}{|c|c|c|c|c|}
\hline Geomorphic element & $\begin{array}{c}\text { Input } \\
(/ \text { in equation 8) } \\
(\mathbf{k g} / \mathbf{y r})\end{array}$ & $\begin{array}{c}\text { Storage } \\
(S \text { in equation 8) } \\
(\mathbf{k g} / \mathrm{yr})\end{array}$ & $\begin{array}{c}\text { Export }(0) \text { using } \\
\text { sediment budget values } \\
\text { of erosion + deposition } \\
\text { (equation } 8) \\
(\mathrm{kg} / \mathrm{yr})\end{array}$ & $\begin{array}{l}\text { Export }(0) \text { using } \\
\text { suspended- } \\
\text { sediment loads } \\
\text { (equation 8) } \\
(\mathrm{kg} / \mathrm{yr})\end{array}$ \\
\hline $\begin{array}{l}\text { Fine-grained sediment transported } \\
\text { out of Linganore Creek } \\
\text { (kg/yr) }\end{array}$ & & & & $-5.45 \times 10^{6}$ \\
\hline $\begin{array}{c}\text { Channel bed } \\
\text { (average }[10 \mathrm{CI} ; 90 \mathrm{CI}] \text { ) }\end{array}$ & $\begin{array}{c}-7.86 \times 10^{4} \\
\left(-2.9 \times 10^{5} ; 1.29 \times 10^{5}\right)\end{array}$ & $\begin{array}{c}7.82 \times 10^{5} \\
\left(-1.26 \times 10^{5} ; 1.80 \times 10^{6}\right)\end{array}$ & & \\
\hline $\begin{array}{c}\text { Flood plain } \\
\text { (average [10CI; 90CI]) }\end{array}$ & & $\begin{array}{c}5.18 \times 10^{6} \\
\left(2.38 \times 10^{6} ; 8.0 \times 10^{6}\right)\end{array}$ & & \\
\hline $\begin{array}{c}\text { Forest } \\
\text { (average [10CI; 90CI]) }\end{array}$ & $\begin{array}{c}-2.03 \times 10^{6} \\
\left(-2.0303 \times 10^{6} ; 2.0274 \times 10^{6}\right)\end{array}$ & & & \\
\hline $\begin{array}{l}\text { Sum of all geomorphic elements } \\
\text { (average [10CI; 90CI]) }\end{array}$ & $\begin{array}{c}-6.33 \times 10^{7} \\
\left(-6.56 \mathrm{E} \times 10^{7} ;-6.17 \times 10^{7}\right)\end{array}$ & $\begin{array}{c}1.63 \times 10^{7} \\
\left(1.47 \times 10^{6} ; 2.21 \times 10^{7}\right)\end{array}$ & $\begin{array}{c}-4.70 \times 10^{7} \\
\left(-4.98 \times 10^{7} ;-4.10 \times 10^{7}\right)\end{array}$ & $-5.45 \times 10^{6}$ \\
\hline $\begin{array}{l}\text { Error in the sediment budget } \\
\quad \text { (average }[10 \mathrm{CI} ; 90 \mathrm{CI}])\end{array}$ & & $\begin{array}{c}4.15 \times 10^{7} \\
\left(3.87 \times 10^{7} ; 4.75 \times 10^{7}\right)\end{array}$ & & \\
\hline $\begin{array}{c}\text { Final equation } 8 \\
\text { (average }[10 \mathrm{CI} ; 90 \mathrm{CI}] \text { ) }\end{array}$ & $\begin{array}{c}-6.33 \times 10^{7} \\
\left(-6.56 \times 10^{7} ;-6.17 \times 107\right)\end{array}$ & $\begin{array}{c}5.78 \times 10^{7} \\
\left(5.46 \times 10^{7} ; 6.62 \times 10^{7}\right)\end{array}$ & & $-5.45 \times 10^{6}$ \\
\hline
\end{tabular}


and forest 3 percent. Since sediment fingerprinting determines the sediment sources that are delivered out of the watershed, combining the two approaches can provide an accounting of the sediment that goes into storage as well as the SDR (Gellis and Walling, 2011) (table 17). For example, according to the sediment fingerprinting results, agricultural lands contributed 45 percent of the total fine-grained sediment transported out of the watershed $\left(-2.45 \times 10^{6} \mathrm{~kg} / \mathrm{yr}\right)$, indicating that 96 percent of the eroded agricultural sediment $\left(5.23 \times 10^{7} \mathrm{~kg} / \mathrm{yr}\right)$ went into storage resulting in a SDR of 4 percent (table 17). Streambanks contributed 52 percent of the total fine-grained sediment transported out of the watershed $\left(-2.84 \times 10^{6} \mathrm{~kg} / \mathrm{yr}\right)$, indicating that 56 percent of the eroded streambanks $\left(3.60 \times 10^{6} \mathrm{~kg} / \mathrm{yr}\right)$ went into storage with a SDR of 44 percent (table 17). Forested areas contributed 3 percent of the total fine-grained sediment transported out of the watershed $\left(-1.64 \times 10^{5} \mathrm{~kg} / \mathrm{yr}\right)$, indicating that 92 percent $\left(1.87 \times 10^{6} \mathrm{~kg} /\right.$ yr) went into storage with a SDR of 8 percent (tables 16 and 17). The amount of bed material in storage $\left(7.86 \times 10^{4} \mathrm{~kg} / \mathrm{yr}\right)$ was not considered a source of sediment in fingerprinting and the amount of sediment eroded from channel beds was assumed to remain in storage.

Of the total amount of sediment deposited into storage $\left(5.78 \times 10^{7} \mathrm{~kg} / \mathrm{yr}\right), 16$ percent was stored in ponds $\left(9.32 \times 10^{6}\right.$ $\mathrm{kg} / \mathrm{yr}), 9$ percent was stored in flood plains $\left(5.18 \times 10^{6} \mathrm{~kg} / \mathrm{yr}\right)$, 2 percent was stored in streambanks $\left(1.04 \times 10^{6} \mathrm{~kg} / \mathrm{yr}\right)$, and 1 percent was stored on the channel bed $\left(7.82 \times 10^{5} \mathrm{~kg} / \mathrm{yr}\right)$, leaving 72 percent $\left(4.15 \times 10^{7} \mathrm{~kg} / \mathrm{yr}\right)$ of the stored sediment that was unaccounted for in the sediment budget (tables 15 and16).

\section{Management Implications}

Results of this study have implications for land-management agencies interested in reducing sediment loads in the Linganore Creek watershed. Combining both the sediment fingerprinting and sediment budget approaches can help identify important sediment sources, eroding reaches of streambanks, and areas of sediment storage. The sediment fingerprinting results (total load weighted percentage) indicate that the two main sources of fine-grained sediment delivered out of the watershed were streambanks (52 percent) and agriculture (45 percent). With the higher SDR for streambanks (44 percent) compared to agriculture (4 percent), management actions to reduce sediment may be more effective in reducing the net export of fine-grained sediment if directed toward stabilizing streambank erosion. Fourth-order streams had the highest rates of streambank erosion ( $12.82 \mathrm{~cm} / \mathrm{yr}$; table 9$)$, with the highest rate of erosion occurring at E15 $(52.7 \mathrm{~cm} / \mathrm{yr})$, a 4th order reach (fig. 17b).

Ponds and flood plains are important sites of sediment storage. There were numerous ponds in the Linganore Creek watershed $(n=195)$ constructed on farms and urban areas that drain 16 percent of the Linganore Creek drainage area. The ponds were estimated to store $9.32 \times 10^{6} \mathrm{~kg} /$ year of finegrained sediment (table 16), which is 15 percent of the total eroded sediment. The estimated amount of sediment deposited on flood plains was $5.18 \times 10^{6} \mathrm{~kg} / \mathrm{yr}$ (table 15), or 8 percent of the total eroded sediment. Modeled rates of flood-plain deposition were highest on 4 th and 5th order channels (appendix 7b).

Table 17. Accounting of sediment storage by combining the sediment fingerprinting results with the sediment budget results.

[kg/yr, kilograms per year; + = deposition, - = erosion; \%, percent $]$

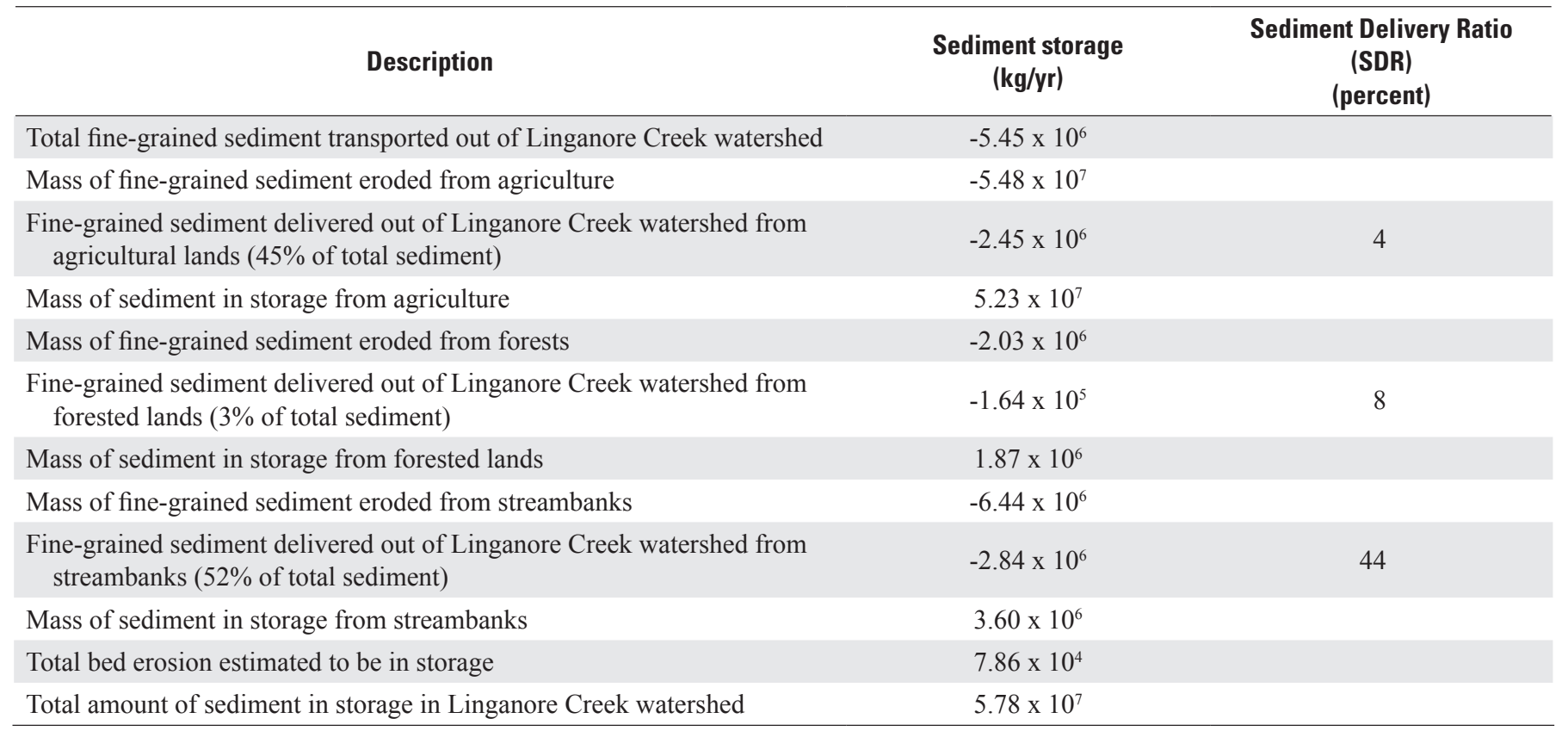




\section{Summary and Conclusions}

Fine-grained sediment is an important pollutant in the Chesapeake Bay and its receiving waters. The U.S. Geological Survey is working on several studies to understand the sources, transport, storage, and delivery of sediment to the Chesapeake Bay and its watershed. This report summarizes the results of a study, in cooperation with Frederick County, to determine the significant sources of fine-grained sediment (silt and clay, less than 63 microns) in the 147-square-kilometer $\left(\mathrm{km}^{2}\right)$ parts of the Linganore Creek watershed in Frederick and Carroll Counties, Maryland, between August 1, 2008 and December 31, 2010. Linganore Creek is listed by the State of Maryland as being impaired by sediment. Linganore Creek also flows into Lake Linganore, an impoundment used for water supply and recreation that is being threatened by sedimentation. Understanding the sources of sediment and important sites of sediment storage in the Linganore Creek watershed may assist management agencies in developing plans to reduce the input of sediment to the streams and receiving waters.

Two approaches were used in the Linganore Creek watershed to identify the significant sources and storage areas of fine-grained sediment - the sediment fingerprinting and sediment budget approaches. The sediment fingerprinting approach determines the sources of fine-grained sediment that is delivered out of the watershed. The sediment budget approach utilizes measurements and estimates to quantify the erosion and deposition of sediment on various geomorphic elements in the watershed (streambanks, flood plains, channel beds, and upland areas). Combining the two approaches can lead to an understanding of areas of high erosion and areas where sediment is being stored.

During the period of study, August 1, 2008 to December 31,2010 , a total mass of 15,840 megagrams of suspended sediment (which includes sand) was transported out of the Linganore Creek watershed. The average annual suspendedsediment load (which includes sand) was 6,374 megagrams per year $(\mathrm{Mg} / \mathrm{yr})$, and the sediment yield was 43.4 megagrams per square kilometer per year, a value within the range of other streams draining the Piedmont Physiographic Province of the Chesapeake Bay. The annual fine-grained suspended-sediment load transported out of the Linganore Creek watershed was $5,454 \mathrm{Mg} / \mathrm{yr}$. Annual rainfall during the study period $(1,020$ millimeters per year, or $\mathrm{mm} / \mathrm{yr}$ ) was similar to the long-term average of $1,047 \mathrm{~mm} / \mathrm{yr}$, indicating that flow and sedimenttransport conditions during the period of study may be similar to the long-term average.

Sources of fine-grained sediment in the Linganore Creek watershed were identified as streambanks, agricultural lands (pasture and cropland), and forested lands. During the period of study, 194 suspended-sediment samples were collected over 36 storm events and used to determine their sources of sediment using the sediment fingerprinting approach. Source samples were collected from 40 streambanks, 24 agricultural areas (cropland and pasture), and 19 forested sites. Sedimentsource percentages were weighted against sediment loads of the individual samples and then weighted against the total sediment transported by the 36 storm events. The total load weighted results indicate that streambanks were the major source of sediment ( 52 percent), followed by agriculture (45 percent), and forested lands (3 percent). Uncertainty analysis indicated that the averages of the Monte Carlo source simulations were within 2 percent of the sediment fingerprinting results. The minimum and maximum values of source percentages produced from the Monte Carlo simulations were within 5 to 10 percent of the average value. Therefore, the final set of source samples and tracers used in this study was considered a robust dataset.

Peak flows and sediment loads for the 36 storm events showed a significant positive relation to contributions from streambanks. Seasonality also is a factor in contributing sediment from streambanks. Winter months (December to February) had the greatest contributions of sediment from streambanks. This may be due to the freeze-thaw activity that occurs in winter months and causes the banks to erode. Higher peak flows that occur in winter months would remove the eroded sediment. High peak flows may also increase bank erosion through increased shear stress and higher porewater pressures on the falling limb of large events.

Peak flows and suspended-sediment loads were also significantly negatively correlated to the contribution of sediment from agriculture. Contributions from forests did not show any relation to flow. Contributions from agriculture were highest in non-winter months and contributions from forests were highest in the fall and winter. The higher contributions from agriculture and forests could be related to less vegetation in the early spring and fall.

Attempting to link upland sediment sources to flow characteristics is difficult since much of the upland sediment that is eroded in an event may not be delivered to the sampling point in that event but may go into storage. Storage areas include channel and upland areas. Sediment from streambanks is delivered directly into the channel, is less likely to be stored prior to delivery to a stream suspended-sediment sampling station, and has a better relation to flow characteristics. By analyzing sediment sources over several storms, it may be possible to determine not only the sediment sources that are directly contributed from the current event but sediment from previous events that was in storage and remobilized. Since seasonal analysis incorporates many storms, the seasonal interpretations of sediment sources may be valid. Because the sediment sampled for the 36 storm events for this study occurred over several years, and over different flow and seasonal conditions, it likely provides a long-term estimation of sediment sources in the watershed.

A fine-grained sediment budget constructed for the Linganore Creek watershed was based on field measurements used to quantify erosion and deposition on the channel beds, streambanks, and flood plains. The Cesium-137 $\left({ }^{137} \mathrm{Cs}\right)$ approach was used to estimate erosion on agricultural and forested slopes. A photogrammetric analysis of ponds in the Linganore Creek watershed (2007 imagery) was used to estimate the amount of sediment deposited in ponds annually. 
Results of the sediment budget for eroded sediment indicated the greatest percentage was from agriculture ( 86 percent; -5.48 x $10^{7}$ kilograms per year, or $\mathrm{kg} / \mathrm{yr}$ ) followed by streambanks (10 percent; - $6.44 \times 10^{6} \mathrm{~kg} / \mathrm{yr}$ ), forests (3 percent; - $2.03 \times 10^{6}$ $\mathrm{kg} / \mathrm{yr}$ ), and the channel bed (less than 1 percent; $-7.86 \times 10^{4}$ $\mathrm{kg} / \mathrm{yr}$ ). Results of the sediment budget for stored sediment indicated that the greatest percentage was stored in ponds (57 percent; $9.32 \times 10^{6} \mathrm{~kg} / \mathrm{yr}$ ), followed by flood plains (32 percent; $5.18 \times 10^{6} \mathrm{~kg} / \mathrm{yr}$ ), streambanks (6 percent; $1.04 \mathrm{x}$ $10^{6} \mathrm{~kg} / \mathrm{yr}$ ), and the channel bed (5 percent; $7.82 \times 10^{5} \mathrm{~kg} / \mathrm{yr}$ ).

Ponds in the Linganore Creek watershed can be important sites of sediment storage. One hundred ninety four ponds were identified from aerial images and drained 16 percent of the Linganore Creek watershed. The majority of these ponds (89 percent) were classified as farm ponds. Of the total storage measured in the sediment budget for the Linganore Creek watershed, the highest percentage of sediment storage (16 percent) was in ponds $\left(9.32 \times 10^{6} \mathrm{~kg} / \mathrm{yr}\right), 9$ percent in flood plains $\left(5.18 \times 10^{6} \mathrm{~kg} / \mathrm{yr}\right), 2$ percent in streambanks $\left(1.04 \times 10^{6}\right.$ $\mathrm{kg} / \mathrm{yr})$, and 1 percent on the channel bed $\left(7.82 \times 10^{5} \mathrm{~kg} / \mathrm{yr}\right)$. Ponds stored 15 percent and flood plains stored 8 percent, respectively, of the total eroded sediment.

Combining all erosion measurements $\left(-6.33 \times 10^{7} \mathrm{~kg} / \mathrm{yr}\right)$ and deposition (storage) measurements $\left(1.63 \times 10^{7} \mathrm{~kg} / \mathrm{yr}\right)$ equaled $-4.70 \times 10^{7} \mathrm{~kg} / \mathrm{yr}$. This indicated that the sediment budget did not balance to the fine-grained sediment mass leaving the watershed measured at the streamflow-gaging station $\left(5.45 \times 10^{6} \mathrm{~kg} / \mathrm{yr}\right)$, leading to an underestimation of $4.15 \times 10^{7}$ $\mathrm{kg} / \mathrm{yr}$, which was assumed to go into storage. The errors in the sediment budget could be due to an overestimation of erosion using the ${ }^{137} \mathrm{Cs}$ method and (or) not adequately measuring storage areas.

The sediment fingerprinting approach quantifies the sources of sediment that are delivered out of the watershed and the sediment budget measures erosion and deposition in the watershed. By combining both approaches, the source areas contributing to sediment storage can be identified. The sediment fingerprinting results indicated that agricultural lands contributed 45 percent of the total fine-grained sediment transported out of the watershed $\left(-2.45 \times 10^{6} \mathrm{~kg} / \mathrm{yr}\right)$ and deposited 96 percent of the eroded sediment $\left(-5.23 \times 10^{7} \mathrm{~kg} / \mathrm{yr}\right)$. Streambanks contributed 52 percent of the total fine-grained sediment transported out of the watershed $\left(-2.84 \times 10^{6} \mathrm{~kg} / \mathrm{yr}\right)$ and deposited 56 percent of the eroded sediment $\left(3.60 \times 10^{6}\right.$ $\mathrm{kg} / \mathrm{yr}$ ). Forested areas contributed 3 percent of the total finegrained sediment transported out of the watershed $\left(-1.64 \times 10^{5}\right.$ $\mathrm{kg} / \mathrm{yr}$ ) and deposited 92 percent of eroded sediment $\left(2.89 \times 10^{6} \mathrm{~kg} / \mathrm{yr}\right)$.

Results of this study demonstrate that combining the sediment fingerprinting and sediment budget approaches provides an accounting of the erosion, storage, and delivery of sediment from sources in the watershed. Useful information on the location of sediment sources, and the amount of sediment eroded and deposited on streambanks, flood plains, channel beds, and uplands can also be obtained by use of both approaches.

\section{Acknowledgments}

Parts of the study were funded by the Frederick County Government, Office of Sustainability and Environmental Resources, Frederick County, Maryland. The authors wish to thank USGS technical reviewers Tanja Williamson and Edward Doheny for suggestions and edits that have improved this manuscript. We would also like to thank Cassandra Ladino (USGS) for assistance in collection of suspended sediment samples in Linganore Creek. University of Maryland, Baltimore County (UMBC) students Katie Powlen and Mitchell Donovan are thanked for their help with data entry and GIS. Andrew Sekellick and Michael Wieczorek (USGS) are also thanked for their assistance with GIS. Anna Baker and Lillian Gorman Sanisaca (USGS) assisted with edits in the statistical model.

\section{References Cited}

Asselman, N.E.M., and Middelkoop, Hans, 1995, Floodplain sedimentation: Quantities, patterns and processes: Earth Surface Processes and Landforms, v. 20, no. 6, p. 481-499, DOI: 10.1002/esp.3290200602.

Banks, W.S.L., Gellis, A.C., and Noe, G., 2010, Sources of fine-grained suspended sediment in Mill Stream Branch watershed, Corsica River Basin, a tributary to the Chesapeake Bay, Maryland, 2009, in Proceedings, 2nd Joint Federal Interagency Sedimentation Conference, Las Vegas, Nevada, June 27-July 1, 2010, CD-ROM ISBN 978-00779007-3-2, 6B, 12 p.

Bevington, P.R., and Robinson, D.K., 2003, Data reduction and error analysis for the physical sciences: New York, McGraw-Hill, 320 p.

Bernard, Claude, Mabit, Lionel, Wicherek, Stanislas, and Laverdière, M.R., 1998, Long-term soil redistribution in a small French watershed as estimated from Cesium-137 data: Journal of Environmental Quality, v. 27, no. 5, p. 1,1781,183, DOI:10.2134/jeq1998.00472425002700050024x.

Brakebill, J.W., Ator, S.W., and Schwarz, G.E., 2010, Sources of suspended-sediment flux in streams of the Chesapeake Bay watershed: A regional application of the SPARROW Model: Journal of the American Water Resources Association, v. 46, no. 4, p. 757-776, DOI:10.1111/j.1752-1688.2010.00450.x

Cambray, R.S., Playford, K., and Lewis, N.J., 1985, Radioactive fallout in air and rain, results to the end of 1984: Harwell, United Kingdom, United Kingdom Atomic Energy Authority Report AERE-R-11915, 7 p.

Carter, M.W., and Moghissi, A.A., 1977, Three decades of nuclear testing: Health Physics, v. 33, no. 1, p. 55-71. 
Chernick, M.R., 2008, Bootstrap methods: A guide for practitioners and researchers ( $2 \mathrm{~d}$ ed.): Hoboken, New Jersey, John Wiley \& Sons, 369 p.

Clune, J.W., Gellis, A.C., and McKee, L.G., 2010, Agricultural soil erosion rates for the Linganore Creek watershed in the Piedmont Physiographic Province of the Chesapeake Bay watershed in Proceedings, 2nd Joint Federal Interagency Conference, Las Vegas, Nevada, June 27-July 1, 2010, CD-ROM ISBN 978-0-0779007-3-2, 7A3, 8 p.

Collins, A.L., and Walling, D.E., 2002, Selecting fingerprint properties for discriminating potential suspended sediment sources in river basins: Journal of Hydrology, v. 261, nos. 1-4, p. 218-244, http://dx.doi.org/10.1016/ S0022-1694(02)00011-2.

Collins, A.L., and Walling, D.E., 2007, Sources of fine sediment recovered from the channel bed of lowland groundwater-fed catchments in the UK: Geomorphology, v. 88 , nos. 1-2, p. 120-138, http://dx.doi.org/10.1016/j. geomorph.2006.10.018.

Collins, A.L., Walling, D.E., and Leeks, G.J.L., 1997, Sediment sources in the Upper Severn catchment: a fingerprinting approach: Hydrology and Earth System Sciences, v. 1, no. 3, p. 509-521, DOI:10.5194/hess-1-509-1997.

Collins, A.L., Walling, D.E., Webb, L., and King, P., 2010, Apportioning catchment scale sediment sources using a modified composite fingerprinting technique incorporating property weightings and prior information: Geoderma, v. 155 , nos. 3-4, p. 249-261, http://dx.doi.org/10.1016/j. geoderma.2009.12.008.

Cooper, C.M., and Knight, S.S., 1990, Nutrient trapping efficiency of a small sediment detention reservoir: Agricultural Water Management, v. 18, no. 2, p. 149-158, http://dx.doi. org/10.1016/0378-3774(90)90027-V.

Coplen, T.B., Brand, W.A., Gehre, Matthias, Gröning, Manfred, Meijer, H.A.J., Toman, Blaza, and Verkouteren, R.M., 2006, New guidelines for $\delta^{13} \mathrm{C}$ measurements: Analytical Chemistry, v. 78, no. 7, p. 2,439-2441, DOI: 10.1021/ac052027c.

Darby, S.E., Rinaldi, Massimo, and Dapporto, Stefano, 2007, Coupled simulations of fluvial erosion and mass wasting for cohesive river banks: Journal of Geophysical Research, v. 112, no. F3, DOI:10.1029/2006JF000722.

De Jong, E., Bettany, J.R., and Villar, H., 1982, Preliminary investigations on the use of 137-Cs to estimate erosion in Saskatchewan: Canadian Journal of Soil Science, v. 62, no. 4, p. 673-683.
Devereux, O.H., Prestegaard, K.L., Needelman, B.A., and Gellis, A.C., 2010, Suspended-sediment sources in an urban watershed, Northeast Branch Anacostia River, Maryland: Hydrological Processes, v. 24, no. 11, p. 1,391-1,403, DOI:10.1002/hyp.7604.

Diaconis, Persi, and Efron, Bradley, 1983, Computer-intensive methods in statistics: Scientific American, v. 248, no. 5, p. 116-130.

DiLisio, J.E., 1983, Maryland: A geography: Boulder, Colorado, Westview Press, Inc., 233 p.

Duijsings, J.J.H.M., 1986, Seasonal variation in the sediment delivery ratio of a forested drainage basin in Luxembourg, in Hadley, R.F., ed., Drainage basin sediment delivery, Proceedings, Albuquerque Symposium, July 1986, IAHS Publication no. 159, p. 153-164.

Edwards, T.K., and Glysson, G.D., 1999, Field methods for measurement of fluvial sediment: U.S. Geological Survey Techniques of Water-Resources Investigations, book 3, chap. C2, 89 p.

Fiener, P., Auerswald, K., and Weigand, S., 2005, Managing erosion and water quality in agricultural watersheds by small detention ponds: Agriculture, Ecosystems and Environment, v. 110, p. 132-142.

Fox, G.A., Chu-Agor, M.L., and Wilson, G.V., 2007, Seepage erosion: A significant mechanism of stream bank failure: Proceedings of the American Society of Civil Engineers (ASCE) World Environmental and Water Resources Congress, May 15-19, 2007, Tampa, Florida, 14 p. (CD-ROM)

Fry, J., Xian, G., Jin, S., Dewitz, J., Homer, C., Yang, L., Barnes, C., Herold, N., and Wickham, J., 2011, Completion of the 2006 National Land Cover Database for the Conterminous United States: Photogrammetric Engineering and Remote Sensing, v. 77, no. 9, p. 858-864.

Gatto, L.W., 1995, Soil freeze-thaw effects on bank erodibility and stability: Hanover, New Hampshire, U.S. Army Corps of Engineers Cold Regions Research and Engineering Laboratory Special Report 95-24, 17 p.

Gellis, A.C., 2013, Factors influencing storm-generated suspended-sediment concentrations and loads in four basins of contrasting land use, humid-tropical Puerto Rico: Catena, v. 104, p. 39-57, http://dx.doi.org/10.1016/j. catena.2012.10.018. 
Gellis, A.C., Banks, W.S.L., Langland, M.J., and Martucci, S., 2005, Summary of suspended-sediment data for streams draining the Chesapeake Bay watershed, water years 19522002: U.S. Geological Survey Scientific Investigations Report 2004-5056, 59 p., accessed February 15, 2014, at http://pubs.usgs.gov/sir/2004/5056/.

Gellis, A.C., and Brakebill, J.W., 2013, Sediment sources and transport in the Chesapeake Bay watershed: U.S. Geological Survey Science Summary, accessed June 15, 2013, at http://chesapeake.usgs.gov/sciencesummarysedimentsourcesandtransport.html.

Gellis, A.C., Hupp, C.R., Pavich, M.J., Landwehr, J.M., Banks, W.S.L., Hubbard, B.E., Langland, M.J., Ritchie, J.C., and Reuter, J.M., 2009, Sources, transport, and storage of sediment at selected sites in the Chesapeake Bay watershed: U.S. Geological Survey Scientific Investigations Report 2008-5186, 95 p., accessed February 15, 2014, at http://pubs.usgs.gov/sir/2008/5186/.

Gellis, A.C., Pavich, M.J., Ellwein, A.L., Aby, S., Clark, I., Wieczorek, M.E., and Viger, R., 2012, Erosion, storage, and transport of sediment in two subbasins of the Rio Puerco, New Mexico: Geological Society of America Bulletin, v. 124, no. 5/6; p. 817-841, http://dx.doi.org/10.1130/ B30392.1.

Gellis, A.C., and Walling, D.E., 2011, Sediment-source fingerprinting (tracing) and sediment budgets as tools in targeting river and watershed restoration programs in Simon, A., Bennett, S., and Castro, J.M., eds., Stream restoration in dynamic fluvial systems: Scientific approaches, analyses, and tools: American Geophysical Union Monograph Series 194, p. 263-291.

Glysson, G.D., 1987, Sediment-transport curves: U.S. Geological Survey Open-File Report 87-218, 47 p.

Harrelson, C.C., Rawlins, C.L., and Potyondy, J.P., 1994, Stream channel reference sites: An illustrated guide to field technique: Fort Collins, Colorado, U.S. Department of Agriculture, Forest Service, Rocky Mountain Forest and Range Experiment Station, General Technical Report RM-245, $61 \mathrm{p}$.

He, Q., and Walling, D.E., 1996, Interpreting particle size effects in the absorption of ${ }^{137} \mathrm{Cs}$ and unsupported ${ }^{210} \mathrm{~Pb}$ by mineral soils and sediments: Journal of Environmental Radioactivity, v. 30, no. 2, p. 117-137.

Hedges, J.I., and Stern, J.H., 1984, Carbon and nitrogen determinations of carbonate-containing solids: Journal of Limnology and Oceanography, v. 29, no. 3, p. 657-663.
Heinemann, H.G., 1981, A new sediment trap efficiency curve for small reservoirs: Water Resources Bulletin, v. 17, no. 5, p. 825-830.

Helsel, D.R., and Hirsch, R.M., 1997, Statistical methods in water resources: Amsterdam, Elsevier Science B.V., 529 p.

Herman, Julie, Hupp, Clifford, and Langland, Michael, 2003, Watershed sediment deposition and storage, chap. 4 of Langland, Michael and Cronin, Thomas, eds., A summary report of sediment processes in Chesapeake Bay and watershed: U.S. Geological Survey Water-Resources Investigations Report 03-4123, p. 42-48, accessed January 15, 2014, at http://pa.water.usgs.gov/reports/wrir03-4123. pdf.

Hooke, J.M., 1979, An analysis of the processes of river bank erosion: Journal of Hydrology, v. 42, nos. 1-2, p. 39-62, http://dx.doi.org/10.1016/0022-1694(79)90005-2.

Horowitz, A.J., 1991, A primer on sediment trace element chemistry: U.S. Geological Survey Open-File Report 91-76, $136 \mathrm{p}$.

Julian, J.P., and Torres, Raymond, 2006, Hydraulic erosion of cohesive riverbanks: Geomorphology, v. 76, nos. 1-2, p. 193-206, http://dx.doi.org/10.1016/j. geomorph.2005.11.003.

Karlin, R., 1980, Sediment sources and clay mineral distributions off the Oregon Coast: Journal of Sedimentary Petrology, v. 50, no. 2., p. 543-559.

Koch, R.W., and Smillie, G.M., 1986, Bias in hydrologic prediction using log-transformed regression models: Journal of the American Water Resources Association (JAWRA), v. 22 , no. 5 , p. $717-723$, DOI: $10.1111 /$ j. $1752-1688.1986$. tb00744.x.

Koltun, G.F., Eberle, M., Gray, J.R., and Glysson, G.D., 2006, User's manual for the Graphical Constituent Loading Analysis System (GCLAS): U.S. Geological Survey Techniques and Methods, book 4, chap. C1, 51 p., accessed February 15, 2014, at http://water.usgs.gov/software/ GCLAS/.

Kondolf, G.M., and Matthews, W.V.G., 1991, Unmeasured residuals in sediment budgets: A cautionary note: Water Resources Research, v. 27, no. 9, p. 2,483-2,486, DOI: 10.1029/91WR01625.

Kraft, J.S., 2002, Soil survey of Frederick County, Maryland: U.S. Department of Agriculture, Natural Resources Conservation Service, $231 \mathrm{p}$. 
Kwaad, F.J.P.M, 1991, Summer and winter regimes of runoff generation and soil erosion on cultivated loess soils (The Netherlands): Earth Surface Processes and Landforms, v. 16, no. 7, p. 653-662, DOI: 10.1002/esp.3290160709.

Langland, Michael, Blomquist, Joel, Moyer, Douglas, and Hyer, Kenneth, 2012, Nutrient and suspended-sediment trends, loads, and yields and development of an indicator of streamwater quality at nontidal sites in the Chesapeake Bay watershed, 1985-2010: U.S. Geological Survey Scientific Investigations Report 2012-5093, 26 p., accessed February 15, 2014, at http://pubs.usgs.gov/sir/2012/5093/.

Lawler, D.M., 1986, River bank erosion and the influence of frost: a statistical examination: Transactions of the Institute of British Geographers, v. 11, p. 227-242.

Leopold, L.B., Emmett, W.W., and Myrick, R.M., 1966, Channel and hillslope processes in a semiarid area, New Mexico: U.S. Geological Survey Professional Paper 352G, 243 p.

Maryland Department of the Environment, 2008, Total Maximum Daily Load of sediment in the Lower Monocacy River Watershed, Frederick, Carroll, and Montgomery Counties, Maryland: Maryland Department of the Environment, Lower Monocacy River Sediment TMDL Document Version, 82 p., September 29, 2008, accessed March 19, 2014, at http:/www.mde.state.md.us/programs/ Water/TMDL/ApprovedFinalTMDLs/Documents/Lower_ Monoc_Sed_TMDL.pdf.

Maryland Department of Natural Resources, 2004, Lower Monocacy River Watershed Characterization: Lower Monocacy River Watershed Characterization Electronic Publication, October 2003, accessed March 17, 2014, at http://dnr.maryland.gov/watersheds/surf/proj/wras.html.

Massoudieh, Arash, Gellis, Allen, Banks, W.S., and Wieczorek, M.E., 2012, Suspended sediment source apportionment in Chesapeake Bay watershed using Bayesian chemical mass balance receptor modeling: Hydrological Processes, v. 27 , no. 24 , p. 3,363-3,374, DOI: $10.1002 /$ hyp. 9429.

Merritts, Dorothy, Walter, Robert, Rahnis, Michael, Hartranft, Jeff, Cox, Scott, Gellis, Allen, Potter, Noel, Hilgartner, William, Langland, Michael, Manion, Lauren, Lippincott, Caitlin, Siddiqui, Sauleh, Rehman, Zain, Scheid, Chris, Kratz, Laura, Shilling, Andrea, Jenschke, Matthew, Datin, Katherine, Cranmer, Elizabeth, Reed, Austin, Matuszewski, Derek, Voli, Mark, Ohlson, Erik, Neugebauer, Ali, Ahamed, Aakash, Neal, Conor, Winter, Allison, and Becker, Steven, 2011, Anthropocene streams and base-level controls from historic dams in the unglaciated mid-Atlantic region, USA: Philosophical Transactions of the Royal Society A: Mathematical, Physical \& Engineering Sciences, v. 369, no. 1938, p. 976-1,009, DOI: 10.1098/rsta.2010.0335.
Minella, J.P.G., Walling, D.E., and Merten, G.H., 2008, Combining sediment source tracing techniques with traditional monitoring to assess the impact of improved land management on catchment sediment yields: Journal of Hydrology, v. 348, nos. 3-4, p. 546-563, http://dx.doi. org/10.1016/j.jhydrol.2007.10.026.

Motha, J.A., Wallbrink, P.J., Hairsine, P.B., and Grayson, R.B., 2003, Determining the sources of suspended sediment in a forested catchment in southeastern Australia: Water Resources Research, v. 39, no. 3, 1056, [variously paged], DOI:10.1029/2001WR000794.

Nagle, G.N., Fahey, T.J., Ritchie, J.C., and Woodbury, P.B., 2007, Variations in sediment sources and yields in the Finger Lakes and Catskills regions of New York: Hydrological Processes, v. 21, no. 6, p. 828-838, DOI: 10.1002/hyp.6611.

Noe, G.B., and Hupp, C.R., 2005, Carbon, nitrogen, and phosphorus accumulation in floodplains of Atlantic Coastal Plain rivers, USA: Ecological Applications v. 15, no. 4, p. 1,178-1,190, http://dx.doi.org/10.1890/04-1677.

Papanicolaou, A.N., Fox, J.F., and Marshall, J., 2003, Soil fingerprinting in the Palouse Basin, USA, using stable carbon and nitrogen isotopes: International Journal of Sediment Research, v. 18, no. 2, p. 278-284, accessed February 15, 2014, at http://tpapanicolaou.engr.utk.edu/files/2013/01/ Copy-of-Isotopes_Pap.pdf.

Pedocchi, F., and Garcia, M.H., 2006, Evaluation of the LISST-ST instrument for suspended particle size distribution and settling velocity measurements: Continental Shelf Research, v. 26, p. 943-958, accessed Februrary 15, 2014, at http://www.sequoiasci.com/wp-content/uploads/2013/07/ Pedocchi_Garcia_2006_CSR.pdf.

Porterfield, G., 1977, Computation of fluvial-sediment discharge: U.S. Geological Survey Techniques of WaterResources Investigations, book 3, chap. C3, 66 p.

Poulenard, J., Perrette, Y., Fanget, B., Quetin, P., Trevisan, D., and Dorioz, J.M., 2009, Infrared spectroscopy tracing of sediment sources in a small rural watershed (French Alps): Science of the Total Environment, v. 407, no. 8, p. 2,8082,819, http://dx.doi.org/10.1016/j.scitotenv.2008.12.049.

R Development Core Team, 2011, R: A language and environment for statistical computing: Vienna, Austria, R Foundation for Statistical Computing, ISBN 3-900051-07-0, accessed March 1, 2014, at http://www.R-project.org/.

Rankl, J.G., 2004, Relations between total-sediment load and peak discharge for rainstorm runoff on five ephemeral streams in Wyoming: U.S. Geological Survey WaterResources Investigations Report 02-4150, 12 p., accessed February 15, 2014, at http:/pubs.usgs.gov/wri/wri024150/. 
Rao, C.R., 1965, Linear statistical inference and its applications: New York, John Wiley \& Sons, Inc., 522 p.

Rausch, D.L., and Schrieber, J.D., 1977, Callahan Reservoir: I. Sediment and nutrient trap efficiency: Transactions of the American Society of Agricultural Engineers, v. 20, no. 2, p. 281-290, accessed February 15, 2014, at http:/www.ars. usda.gov/sp2UserFiles/Place/50701000/cswq-t2808-rausch. pdf.

Renwick, W.H., Smith, S.V., Bartley, J.D., and Buddemeier, R.W., 2005, The role of impoundments in the sediment budget of the conterminous United States: Geomorphology, v. 71, nos. 1-2, p. 99-111, http://dx.doi.org/10.1016/j. geomorph.2004.01.010.

Révész, K., and Qi, H., 2006, Determination of the $\delta\left({ }^{15} \mathrm{~N} /{ }^{14} \mathrm{~N}\right)$ and $\delta\left({ }^{13} \mathrm{C} /{ }^{12} \mathrm{C}\right)$ of total $\mathrm{N}$ and $\mathrm{C}$ in Solids: RSIL Lab Code 1832, chap. C5 of Révész, Kinga, and Coplen, T.B., eds., Methods of the Reston Stable Isotope Laboratory: U.S. Geological Survey Techniques and Methods, book 10, chap. C5, $31 \mathrm{p}$.

Ritchie, J.C., 2000, Combining ${ }^{137} \mathrm{Cs}$ and topographic surveys for measuring soil erosion/deposition patterns in a rapidly accreting area: Acta Geologica Hispanica v. 35, nos. 3-4, p. 207-212, accessed February 15, 2014, at http://www. geologica-acta.com/pdf/aghv3503a02.pdf.

Ritchie, J.C., and McHenry, J.R., 1990, Application of radioactive fallout Cesium-137 for measuring soil erosion and sediment accumulation rates and patterns: A review: Journal of Environmental Quality, v. 19, no. 2, p. 215-233, DOI:10.2134/jeq1990.00472425001900020006x.

Ritchie, J.C., Nearing, M.A., Nichols, M.H., and Ritchie, C.A., 2005, Patterns of soil erosion and redeposition on Lucky Hills watershed, Walnut Gulch Experimental watershed, Arizona: Catena, v. 61, nos. 2-3, p. 122-130, http://dx.doi. org/10.1016/j.catena.2005.03.012.

Ross, K.M., Hupp, C.R., and Howard, A.D., 2004, Sedimentation in floodplains of selected tributaries of the Chesapeake Bay in Bennett, S.J and Simon, A. eds., Riparian vegetation and fluvial geomorphology: American Geophysical Union, Water Science and Applications 8, p. 187-208.

SAS Institute, 2004, SAS/STAT 9.0 users' guide: Cary, North Carolina, SAS Institute, Inc., [variously paged].

Sauer, V.B., and Meyer, R.W., 1992, Determination of error in individual discharge measurements: U.S. Geological Survey Open-File Report 92-144, 21 p., accessed February 15, 2014, at http://pubs.usgs.gov/of/1992/ofr92-144/.
Schenk, E.R., Hupp, C.R., Gellis, Allen and Noe, Greg, 2012, Developing a new stream metric for comparing stream function using a bank-floodplain sediment budget: a case study of three Piedmont streams: Earth Surface Processes and Landforms, v. 38, no. 8, p. 771-784, DOI: 10.1002/ esp. 3314 .

Sekellick, A.J., and Banks, W.S.L., 2010, Water volume and sediment accumulation in Lake Linganore, Frederick County, Maryland, 2009: U.S. Geological Survey Scientific Investigations Report 2010-5174, 14 p., accessed February 15, 2014, at http://pubs.usgs.gov/sir/2010/5174/.

Simm, D.J. and Walling, D.E., 1998, Lateral variability of overbank sedimentation on a Devon flood plain: Hydrological Sciences, v. 43, no. 5, p. 715-732, DOI:10.1080/02626669809492168.

Simon, Andrew, Curini, Andrea, Darby, S.E., and Langendoen, E.J., 2000, Bank and near-bank processes in an incised channel: Geomorphology, v. 35, nos. 3-4, p. 193-217, http://dx.doi.org/10.1016/S0169-555X(00)00036-2.

Skalak, Katherine, and Pizzuto, James, 2010, The distribution and residence time of suspended sediment stored within the channel margins of a gravel-bed bedrock river: Earth Surface Processes and Landforms, v. 35, p. 435-446, DOI: $10.1002 /$ esp.1926.

Slattery, MC., Walden, J., and Burt, T.P., 2000, Fingerprinting suspended sediment sources using mineral magnetic measurements - A quantitative approach, in Foster, I., ed., Tracers in geomorphology: New York, John Wiley \& Sons, p. 309-322.

Sprague, Eric, Burke, David, Claggett, Sally, and Todd, Albert, eds., 2006, The State of Chesapeake Forests. The Northeastern Area Chesapeake Bay Watershed Forestry Program: Annapolis, Maryland, The Conservation Fund and U.S. Department of Agriculture Forest Service, 115 p., accessed June 1, 2013, at http://www.chesapeakebay.net/ content/publications/cbp_19673.pdf.

Steegen, A., Govers, G., Beuselinck, L., Nachtergaele, J., Takken, I., and Poesen, P., 1998, Variations in sediment yield from an agricultural drainage basin in central Belgium in Summer, W., Klaghofer, E., and Zhang, W., eds., Modeling soil erosion, sediment transport and closely related hydrological processes: International Association of Hydrological Sciences (IAHS) publication 249, p. 177-185.

Stuart, Alan, and Ord, K.J., 1991, Kendall's advanced theory of statistics v. 2, (5th ed.): New York, Oxford Press, 1,323 p.

Sutherland, R.A., 1989, Quantification of accelerated soil erosion using the environmental tracer caesium-137: Land Degradation \& Development, v. 1, no. 3, p. 199-208, DOI: $10.1002 / 1 \mathrm{dr} .3400010304$. 
Swanson, F.J., Janda, R.J., Dunne, T., and Swanston, D.N., 1982, Sediment budgets and routing in forested drainage basins: U.S. Department of Agriculture, Forest Service, Pacific Northwest Forest and Range Experiment Station, General Technical Report PNW-141, 165 p.

U.S. Department of Agriculture (USDA), National Agricultural Statistics Service, 2009, 2007 Census of Agriculture Maryland and County Data: Washington, D.C., $375 \mathrm{p}$.

U.S. Department of Agriculture, 2009, Maryland Conservation Reserve Enhancement Program (CREP): U.S. Department of Agriculture, Farm Service Agency, Fact Sheet, April 2009, 3 p., accessed May 16, 2014, at http://www.fsa.usda. gov/Internet/FSA_File/mdcrep.pdf.

U.S. Department of Agriculture (USDA), Natural Resources Conservation Service (NRCS), 2006, Farm pond ecosystems: U.S. Department of Agriculture, Natural Resources Conservation Service, Fish and Wildlife Habitat Management Leaflet number 29, February 2006, 12 p., accessed September 30, 2012, at http://directives.nrcs.usda. gov/OpenNonWebContent.aspx? content=18500.wba.

U.S. Department of Commerce, National Oceanic and Atmospheric Administration, National Climatic Data Center (NCDC), 2011, Climatic data online, global summary of the day: National Climatic Data Center, U.S. Oceanic and Atmospheric Administration, accessed July 11, 2011, at http://www.ncdc.noaa.gov/cdo-web/.

U.S. Department of Commerce, National Oceanic and Atmospheric Administration (NOAA), 2013a, National Climatic Data Center, Climate Data Online, accessed June 10, 2013, at http://www.ncdc.noaa.gov/cdo-web/.

U.S. Department of Commerce, National Oceanic and Atmospheric Administration (NOAA), 2013b, National Weather Service, Hydrometeorological Design Studies Center, Precipitation Frequency Data Server (PFDS), accessed June 10, 2013, at http://hdsc.nws.noaa.gov/hdsc/ pfds/.

Versar, 2002, Watershed assessment of lower Linganore Creek, Frederick County, Maryland: Chapter 2, Watershed Characteristics, Report prepared for Frederick County, Division of Public Works: Unpublished report, Chapter 2, Versar, Inc., Columbia, Maryland, accessed March 21, 2013, at http://www.watershed-alliance.com/publications/ Linganore/Linganore\%20WSA/WSA_ch2.PDF.
Verstraeten, Gert, and Poesen, Jean, 2000, Estimating trap efficiency of small reservoirs and ponds: methods and implications for the assessment of sediment yield: Progress in Physical Geography, v. 24, no. 2, p. 219-251, DOI: $10.1177 / 030913330002400204$.

Wainer, H., 1976, Robust statistics: A survey and some prescriptions: Journal of Educational Statistics, v. 1, no. 4, p. 285-312.

Walling, D.E., 2005, Tracing suspended sediment sources in catchments and river systems: Science of the Total Environment, v. 344, nos. 1-3, p. 159-184, http://dx.doi. org/10.1016/j.scitotenv.2005.02.011.

Walling, D.E., and He, Q., 1997, Models for converting ${ }^{137} \mathrm{Cs}$ measurements to estimates for soil redistribution on cultivated and uncultivated soils (including software for model implementation): A contribution to the United Nations, International Atomic Energy Agency (IAEA) Coordinated Research Programmes on Soil Erosion (D1.50.05) and Sedimentation (F3.10.01): Exeter, United Kingdom, University of Exeter, $30 \mathrm{p}$.

Walling, D.E., Owens, P.N., and Leeks, G.J.L., 1999, Fingerprinting suspended sediment sources in the catchment of the River Ouse, Yorkshire, UK: Hydrological Processes, v. 13, no. 7, p. 955-975, DOI: $10.1002 /$ (SICI)1099-1085(199905).

Walling, D.E., and Woodward, J.C., 1992, Use of radiometric fingerprints to derive information on suspended sediment sources, in erosion and sediment transport monitoring programmes in river basins: Proceedings of the Oslo Symposium, August 1992, International Association of Hydrological Sciences (IAHS) Publication Number 210, p. 153-164.

Wolf, K.L., Ahn, Changwoo, and Noe, G.B., 2011, Development of soil properties and nitrogen cycling in created wetlands: Wetlands v. 31, no. 4, p. 699-712, DOI 10.1007/s13157-011-0185-4.

Wolman, M.G., 1959, Factors influencing erosion of a cohesive river bank: American Journal of Science, v. 257, p. 204-216.

Wynn, T., 2006, Streambank retreat—A primer: Watershed Update, January-March 2006, American Water Resources Association Hydrology and Watershed Management Technical Committee, v. 4, no. 1, p. 1-14, accessed February 15, 2014, at http://www.awra.org/committees/ techcom/watershed/pdfs/0401WU.pdf. 
Prepared by USGS West Trenton Publishing Service Center. Edited by Valerie M. Gaine.

Graphics and layout by Timothy W. Auer.

For additional information, contact:

Director, MD-DE-DC Water Science Center

U.S. Geological Survey

5522 Research Park Drive

Baltimore, MD 21228

or visit our Web site at:

http://md.water.usgs.gov 
